Graphical Abstract

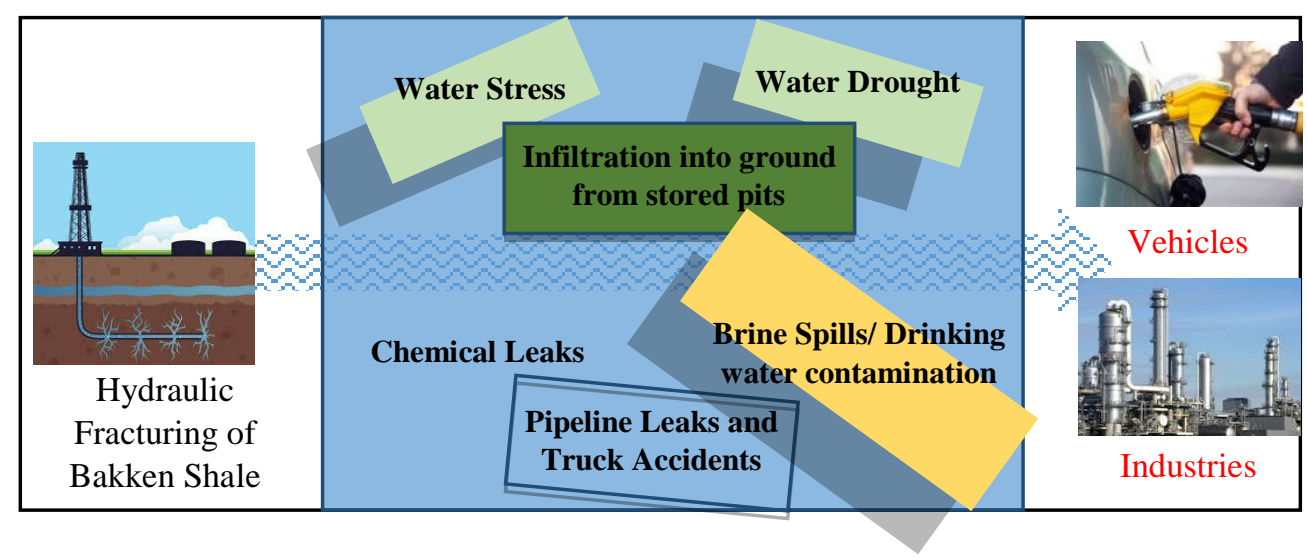

(C) 2016. This manuscript version is made available under the Elsevier user license http://www.elsevier.com/open-access/userlicense/1.0/ 


\section{POTENTIAL WATER RESOURCE IMPACTS OF HYDRAULIC FRACTURING FROM UNCONVENTIONAL OIL PRODUCTION IN THE BAKKEN SHALE}

Namita Shrestha ${ }^{1}$, Govinda Chilkoor ${ }^{1}$, Joseph Wilder ${ }^{1}$, Venkataramana Gadhamshetty ${ }^{1 *}$, James J.

$$
\text { Stone }^{1}
$$




\section{Abstract}

18 Modern drilling techniques, notably horizontal drilling and hydraulic fracturing, have enabled

19 unconventional oil production (UOP) from the previously inaccessible Bakken Shale Formation

20 located throughout Montana, North Dakota (ND) and the Canadian province of Saskatchewan.

21 The majority of UOP from the Bakken shale occurs in ND, strengthening its oil industry and

22 businesses, job market, and its gross domestic product. However, similar to UOP from other low-

23 permeability shales, UOP from the Bakken shale can result in environmental and human health

24 effects. For example, UOP from the ND Bakken shale generates a voluminous amount of saline

25 wastewater including produced and flowback water that are characterized by unusual levels of 26 total dissolved solids $(350 \mathrm{~g} / \mathrm{L})$ and elevated levels of toxic and radioactive substances.

27 Currently, 95\% of the saline wastewater is piped or trucked onsite prior to disposal into Class II 28 injection wells. Oil and gas wastewater (OGW) spills that occur during transport to injection 29 sites can potentially result in drinking water resource contamination. This study presents a 30 critical review of potential water resource impacts due to deterministic (freshwater withdrawals 31 and produced water management) and probabilistic events (spills due to leaking pipelines and 32 truck accidents) related to UOP from the Bakken shale in ND.

37 Keywords: Bakken, corrosion, energy use and resources, hydraulic fracturing, horizontal drilling 


\subsection{Introduction}

40 The state of North Dakota (ND) in the upper Great Plains (UGP) region (South Dakota (SD),

41 Montana (MT), Wyoming (WY), Nebraska (NE), and ND) has adopted unconventional drilling

42 techniques, notably multi-stage horizontal drilling and hydraulic fracturing $(\mathrm{HF})$ techniques, to

43 extract crude oil from the previously inaccessible Bakken Shale Formation (Gaswirth et al.,

44 2013). While the Bakken Shale Formation is located throughout MT, ND and the Canadian

45 provinces of Saskatchewan and Manitoba, the majority of unconventional oil production (UOP)

46 occurs in ND (U.S. EIA, 2016). "Pad drilling," the use of multiple horizontal wells (>4) in the

47 same pad, has enabled a cost-effective route for oil production, allowing the UOP rate in ND to

48 reach as high as 1,350 thousand bbl/d (North Dakota Industrial Commission, 2014). According

49 to the ND Department of Mineral Resources (NDDMR), nearly 10,160 Bakken wells were

50 horizontally drilled in the last 15 years (Murex Petroleum Corporation, 2014; North Dakota

51 Department of Mineral Resources, 2015). UOP has strengthened oil industries and businesses

52 (e.g., excavation equipment such as backhoes and front-end loaders, machinery for frack-sand

53 mining) (Holloway and Rudd, 2013), creating new job opportunities and increasing the gross

54 domestic product in ND by nearly $11 \%$ in 2012 (Horner et al., 2016). However, similar to UOP

55 from other low-permeability shales, UOP from the Bakken shale can result in environmental

56 issues related to altered land usage (Moran et al., 2015), stressed pipeline and railway

57 infrastructure (Rahm et al., 2015), water shortages and environmental and human health risks

58 (Kassotis et al., 2015; Stamford and Azapagic, 2014; Webb et al., 2014) due to water resource

59 contamination (Entrekin et al., 2011).

60 
As suggested by the Environmental Protection Agency (EPA) (U.S. EPA, 2015b), UOP

62 from tight geological formations such as the Bakken shale affects regional water resources

63 during the five stages of the HF water cycle (see Figure 1). Oil industries in ND acquire and

64 transport large volumes of freshwater from the Missouri River or the water depots to well sites

65 (Stage I) (Horner et al., 2016; Jiang et al., 2014). The over-extraction of freshwater may create

66 water stress during drought periods and restrict water access for production of typical

67 agricultural products (durum and wheat), special commodities (sunflowers, safflower, canola,

68 flaxseed, lentils, dry beans, and honey), biofuel feedstock (corn and soybean) and energy (corn-

69 based ethanol and coal-fired power) in ND (Torres et al., 2016). A recent study by Horner et al.

70 (2016) concluded that existing ground water resources in ND are not adequate to meet

71 anticipated increases in freshwater demand for UOP. In Stage II, water-based fracturing fluids

72 are prepared by mixing freshwater with proppants and fracturing chemicals (Jiang et al., 2014).

73 Pumping trucks are used to inject fracturing fluids at high pressures (0.75 psi/ft) (Murex

74 Petroleum Corporation, 2014) to fracture oil-bearing rocks and carry proppants to hold open the

75 fractures and stimulate UOP from the Bakken shale (Stage III). Chemical spills during Stages II

76 and III can contaminate surface and groundwater resources (Torres et al., 2016). Well-casing

77 failures and existing faults or fractures in geological formations between target formations and

78 aquifers can potentially result in migration of toxic fracturing fluids into drinking water

79 resources (Rogers et al., 2015).

80

81 UOP generates a significant amount of saline wastewater (flowback or produced water)

82 (Stage IV), which is transported to disposal sites for subsequent injection into Class II injection

83 wells (Stage V) (Figure 1) (North Dakota Department of Health, 2015b). In Stages IV and V, 
84 truck accidents and pipeline breaks during transport of the saline wastewater have resulted in

85 several brine spills (fracturing fluids, flowback water and produced water) (North Dakota

86 Department of Health, 2015b) that threaten the land and water resources in ND (Lauer et al.,

87 2016; Pichtel, 2016). For example, in 2014, an accidental spill contaminated 9,000 $\mathrm{ft}^{2}$ of land in

88 William County with 150 barrels of produced water (North Dakota Department of Health,

89 2014a). The UOP wells in ND are located throughout a range of agricultural lands (e.g., wheat

90 and durum) and near water resources (Missouri River and aquifers) (Jacobson, 2015; Griswold,

91 2014), increasing risks for water and food contamination.

92

93 ND contributes $12.5 \%$ of the total crude oil production and accounts for only $0.6 \%$ of the

94 total energy consumption in the United States (U.S.) (US EIA, 2014). Due to limited oil refining

95 capacity in ND $\left(92,860\right.$ bbl.day $^{-1}$ of crude oil $)$, the bulk of the oil is exported to the east and west

96 coasts using trucks, pipeline and railway infrastructure (U.S. EIA, 2014c). Inadequate

97 transportation infrastructure to handle massive volumes of oil has been cited as a reason for the

98 increasing number of transportation-related spills in ND (Federman, 2014; Gadhamshetty et al.,

99 2015; North Dakota Department of Health, 2014b). Nearly 6.5\% of transportation-related

100 accidents in the Bakken region have been attributed to inadequate railway infrastructure

101 (Bradley, 2014; Mitchell and Child, 2015). The roadways in a 17-county oil region of western

102 ND have been experiencing sharp increases in traffic volume, shifts in traffic mix, and large

103 increases in vehicle crashes in the past few years (Upper Great Plains Transportation Institute,

104 2015). The roadways previously used only for local access and agricultural purposes continue to

105 be used at higher volumes to serve the oil industry, resulting in ongoing traffic safety issues

106 (Upper Great Plains Transportation Institute, 2015). The number of rural road crashes involving 
107 trucks in Bakken regions has increased by 109\% from 2010 to 2014 (Upper Great Plains

108 Transportation Institute, 2015).

109

110 From an oil exploration standpoint, the Bakken shale serves as an in situ geological

111 laboratory for developing new assessment techniques for estimating recoverable oil volume from

112 tight shales. From a commercial standpoint, the Bakken shale is the primary target for private 113 industries exploring for crude oil in the UGP (U.S. EIA, 2014a; 2013b). From an environmental

114 standpoint, the Bakken shale is a platform for establishing baseline data for environmental

115 impacts due to UOP, for the reasons discussed below. Compared to oil and gas production in

116 Colorado (CO), Nebraska (NE), Pennsylvania (PA), Texas (TX) and Wyoming (WY) that dates

117 back to the late $19^{\text {th }}$ century (U.S. EIA, 2015a; 2014 ), UOP from the Bakken Shale Formation

118 began only after the discovery of the Parshall field in 2007 (Bakken-Lodgepole, 2008; Higley

119 and Cox, 2007). ND has a relative short industrial history compared to its eastern counterparts,

120 and it is therefore easier to segregate environmental impacts due to UOP. However, there is a

121 paucity of peer-reviewed information on environmental impacts due to UOP in ND (EERC,

122 2010; Gordon and Garner, 2014; Horner et al., 2016; Lauer et al., 2016; Smith, 2009). For

123 example, since 2007, nearly 3900 brine spills have occurred during transportation of wastewater

124 from well sites to Class II injection wells (Lauer et al., 2016) in ND, and there are very few

125 studies that have investigated their environmental impacts. Lauer et al. (2015) have studied two

126 brine spills in ND (the Bear Den Bay spill and the Blacktail Creek spill) and established that the

127 affected sites accumulated a range of contaminants (salts, inorganic chemicals, and metals). The

128 spill events can therefore be expected to influence water resources for several years after they

129 occur (Lauer et al., 2016). 
131 The literature suggests an increasing number of studies related on water resource impacts

132 due to UOP from contemporary shales (Kahrilas et al., 2014; Stringfellow et al., 2014; Uddameri

133 et al., 2014; Vengosh et al., 2014) including the Marcellus (Haluszczak et al., 2013) and

134 Niobrara shales (Lester et al., 2015). Recent studies have established that spill sites in the

135 Marcellus shale are characterized by elevated levels of halides ( $28 \mathrm{mg} / \mathrm{L}$ iodide $)$ and ammonia

$136(\sim 106 \mathrm{mg} / \mathrm{L})$ (Harkness et al., 2015) that can impact stream ecosystems and result in the

137 formation of brominated, iodinated, and nitrogen disinfection byproducts during chlorination at

138 downstream water treatment plants. Their findings have indicated that discharges and accidental

139 spills of produced water to waterways pose environmental and health risks. Vengosh et al. (2014)

140 have identified and reviewed the following four potential water resource impacts due to gas

141 production from the Marcellus, Haynesville, and Barnett shales: stray gas contamination; spills,

142 leaks, and disposal of untreated shale gas wastewater; accumulation of toxic and radioactive

143 elements in soil and stream sediments; and water shortages due to excessive freshwater

144 consumption. However, the current literature lacks such a detailed studies on water resource

145 impacts due to UOP in ND.

147 This paper presents a critical overview of recent studies (through September 2016) 148 related to potential water resource impacts due to UOP in ND. This study focuses on the 149 potential sources of water resource degradation during the HF water lifecycle described in Figure 150 1, which include the following: (1) high-volume freshwater withdrawals during water acquisition 151 (Stage I) and (2) surface and ground water contamination due to spills associated with flowback 152 and produced water management (Stages III and IV). We present a critical discussion on water 
153 resources impacts due to both the deterministic (freshwater withdrawals and produced water

154 management) and probabilistic events (oil spills, leaking pipelines, truck accidents) related to

155 UOP in ND. We also present an overview of experimentally determined information (type and

156 quantity) for fracturing contaminants detected in the following sources in ND: i) flowback and

157 produced water and ii) sites affected by brine spills and pipeline accidents. The subsequent

158 sections of the paper discuss the environmental oversight for UOP by the federal and ND state

159 agencies. Due to the limited amount of peer-reviewed literature related to UOP in ND, the study

160 is based on both scientific journal articles and the gray literature, including annual reports and

161 technical documents from ND stage agencies (ND Industrial Commission (NDIC), NDDMR,

162 North Dakota Department of Health (NDDH), ND State Water Commission) and oil industries.

163

$164 \quad 2.0 \quad$ Increase in crude oil production in the Bakken shale and consequences of existing

165 crude oil infrastructure

166 The Williston Basin encompasses 135,000 square miles of flat, rolling land surface that extends

167 into MT, ND, SD, and WY. Figure 2 shows a topographic map of the UGP region defining the

168 boundaries of the Williston Basin (red), the Bakken Formation (blue), the prairie pothole region

169 (yellow) and the Missouri River system. The Williston Basin is underlain by sedimentary rocks

170 such as sandstone, coal, and shale. The Bakken shale in the Williston Basin contains coal/lignite,

171 natural gas, and uranium. The U.S. Geological Survey (USGS) has confirmed that the Tertiary

172 and Upper Cretaceous geologic units in the Bakken shale are major crude oil reservoirs (Figure

173 2). Horizontal drilling techniques have enabled oil extraction from the previously inaccessible

174 (impermeable) Bakken formation (Gaswirth et al., 2013).

175 
177 gas production, rig count, and oil production per rig) for the Bakken shale with that of the

178 Permian (TX), the Niobrara (CO, Kansas (KS), and WY) and the Marcellus shales (Ohio (OH),

179 West Virginia (WV), PA, New York (NY)) through July 2016. As shown, the Permian shale

180 produces the highest amount of oil compared to the Bakken, Niobrara, and Marcellus shales

181 (U.S. EIA, 2015c). TX is the largest crude oil-producing state, and ND is the second-largest oil-

182 producing state in the U.S. As of September 2015, 10,298 wells were extracting 1.1 million

183 barrels (MMbbl) of crude oil daily (Figure 3) (North Dakota Department of Mineral Resources,

184 2015). Oil production volumes in ND and TX increased at average annual rates of $37 \%$ and $28 \%$,

185 respectively, from April 2010 to April 2014 (U.S. EIA, 2014b) (Figure 3). The emerging

186 literature suggests a correlation between the increasing volume of oil production and the

187 increasing number of water resource impacts (Horner et al., 2016; Lauer et al., 2016).

As shown in Figure 3c, a sharp decrease in rig counts in all four shale locations since

190 January 2013 is attributed to declining oil prices (U.S. EIA, 2015b). When oil companies decide

191 to reduce the number of rigs in an oil field, they begin the process by idling the oldest and least

192 efficient rigs. Therefore, the impact of reducing the number of rigs on cumulative oil production

193 depends upon the productivity of the remaining rigs. During the 2008-09 recession, decreasing

194 oil prices resulted in reduced rig counts without affecting cumulative oil production (Figure 3).

195 The decreased oil production due to reduced rig count was compensated by increased 196 productivity of remaining rigs. The productive rigs facilitate well completion at faster rates, 197 enhance initial production rates, and enable oil companies to drill multiple horizontal wells from 198 a single pad (U.S. EIA, 2015b). However, the rapid production rates can result in higher truck 
199 traffic and a higher probability of water stress, surface spills or leaks, truck traffic, and potential 200 surface and groundwater contamination (Vengosh et al., 2014).

UOP from the Bakken shale has increased from 150 thousand bbl/d in 2007 to 1,350

203 thousand bbl/d in 2015 (North Dakota Industrial Commission, 2014). However, the

204 transportation infrastructure has not been upgraded at a rapid enough pace to handle the high 205 volumes of UOP and export the oil to neighboring states (Hamilton, 2008). The aged railways 206 used to transport 700,000 barrels of oil daily to refineries have been reported as vulnerable to 207 accidents (Shea et al., 2015). Trucks (56\%) and pipelines (44\%) used to transport the crude oil 208 from well sites to rail terminals or pipelines (Lord et al., 2015) have also been considered 209 vulnerable to accidents, resulting in regional oil spills (details in Section 4.0). The challenging 210 climate of ND further influences the supply chain and lowers the UOP rate. During heavy 211 snowstorms that are common in the area, once the onsite storage tanks are filled, the production 212 of crude oil cannot resume until weather supports oil transportation. Nearly 80\% of ND's crude

213 oil production occurs in Dunn, Montrail, William and McKenzie counties, and harsh weather in 214 these areas retards crude oil production and transportation rates (U.S. EIA, 2013a). For example, 215 in 2014, unfavorable weather conditions were considered as the primary factor for $18 \%$ of 216 vehicle crashes in the oil counties of ND (Upper Great Plains Transportation Institute, 2015).

\section{$218 \quad 3.0 \quad$ Water resource impacts}

$2193.1 \quad$ Overview of Bakken shale members and the Williston Basin

220 The Williston Basin in the north-central U.S. and south-central Canada has been a leading source 221 of oil and gas during the past 50 years (USGS, 2014a). Unconventional drilling techniques have 
222 enhanced UOP from the Bakken and Three Forks Formations in the Williston Basin. With 223 widespread oil production in the Williston Basin, the USGS emphasizes the need for 224 comprehensive research and development (R\&D) studies to understand the effects of increased 225 energy production on regional land and water resources. As shown in Figure 2, a major portion 226 of the Williston Basin is overlain by the prairie pothole region known for its digressional 227 wetlands that promote breeding and nesting habitats for North America's migratory waterfowl 228 and miscellaneous wildlife (U.S.Geological Survey, 2015). The Tertiary and Upper Cretaceous 229 geological units of the Bakken shale represent oil reservoirs (Figure 2). Overlying aquifers in the 230 glacial sediments and Upper Cretaceous and Lower Tertiary systems are water resources in the

231 Williston Basin (U.S.Geological Survey, 2015), representing a need to monitor and assess the 232 impacts of HF activities (e.g., oil and produced water spills) on regional water resources (USGS, 233 2014b). In the following sections, existing knowledge about each stage of the HF water cycle 234 will be summarized and its consequences for water resource impacts will be assessed.

$236 \quad 3.2 \quad$ Water Acquisition, chemical mixing and well injection (Stage I, II and III)

237 The water-based fracturing fluids used to stimulate UOP from the Bakken shale offer low 238 frictional losses and effectively inject the proppants into fractures. However, water-based fluids 239 consume significant amounts of freshwater for i) consumptive uses (e.g., chemical mixing and 240 preparing drilling fluid) and ii) indirect sinks (e.g., well construction) (see Figure 1). HF 241 contributes to nearly $4 \%$ of total freshwater consumption in ND (North Dakota State Water 242 Commission, 2014), and the consumption rate is expected to increase by $85 \%$ in the next ten 243 years (North Dakota State Water Commission, 2015a). 
The ND State Water Commission has reported its concerns about declining pressure in

246 aquifers and is hesitant to permit oil industries to extract potable groundwater, limiting oil

247 industries in western ND to seeking freshwater from surface water, municipalities, or public and

248 private water depots. The surface water resources in ND are primarily based on the Missouri

249 River reservoir system that includes six dams and a reservoir that are managed by the U.S. Army

250 Corps of Engineers (USACE) (Kurz et al., 2011; North Dakota State Water Commission,

251 2015b). Water depots obtain water from both groundwater reserves and surface water (Horner et

252 al., 2016; Kurz et al., 2011). While ND may have adequate surface water reserves to meet

253 freshwater demands for UOP, it has been reported that the USACE currently restricts Missouri

254 River water usage for Bakken oil production (Horner et al., 2016; North Dakota State Water

255 Commission, 2015b). The Western Area Water Supply Project (WAWSP)—a domestic water

256 project that uses Missouri River water, treats it at the Williston regional water treatment plant,

257 and supplements it with groundwater-is an alternate freshwater source for fracturing activities

258 in ND (Western Area Water Supply Agency ((WAWSA, 2016). In addition to meeting

259 municipal, rural and industrial water needs for five northwestern ND counties, WAWSA is

260 expanding $20 \%$ of its current water supply to meet UOP needs. WAWSA sells water at nine

261 water depots or transports the water to oil fields through dedicated pipelines (WAWSA, 2015).

262 As discussed in later sections, unusual levels of salinity in wastewater in the Bakken fields

263 prevent its reuse for UOP. This explains why the Marcellus oil field recycles $90 \%$ of its

264 produced water (Clark et al., 2013), but none is recycled in the Bakken play (Horner et al., 265 2016). 
268 Geology in 2015 estimated that the Bakken region may gain nearly 2,500 new oil wells per year

269 in the next 15-25 years (Plummer et al., 2015). With anticipated growth in the oil industry, it is

270 important to develop accurate estimates and predict whether adequate freshwater is available for

271 increasing UOP in ND (North Dakota State Water Commission, 2014). Table 1 shows the total

272 number of wells and annual total water consumption for UOP in ND. The freshwater

273 consumption for UOP has increased 5-fold from 2008 to 2012 (Table 1). The lateral length in the

274 Bakken has increased by 25\% from 2009 to 2013 (Horner et al., 2016), and the corresponding

275 water consumption has increased four-fold in this period (Table 1). The specific water

276 requirements for a given Bakken well depend upon the type of fracturing technique and the

277 number of fracturing stages (Kurz et al., 2011). Scanlon et al. (2014) estimated that the 7868

278 Bakken wells consumed 15.8 Mgal of freshwater from 2005 to 2013, and on average, each well 279 consumed 4.8 Mgal water (Scanlon et al., 2014).

The freshwater consumption for UOP in ND can be expected to be at least $20 \%$ higher 282 per well when water consumption for drilling and cementing are taken into account (Scanlon et 283 al., 2014). Other indirect sinks for UOP are discussed below. Nearly 10-15\% of the Bakken wells 284 require maintenance water, or freshwater to minimize salinity buildup, and this quantity ranges 285 as high as 5 Mgal per well. Due to high salinity, the maintenance water requirements for the 286 Bakken play are significantly higher than for contemporary shales (e.g., Eagle Ford) (Horner et 287 al., 2016). Further, the Bakken wells in the western region of ND require higher maintenance 288 water compared to their eastern counterparts (Horner et al., 2016). The temporary workers (who 289 come to the region only to take jobs related to UOP) in ND exerts significant freshwater 
290 demands for their domestic needs. The freshwater demand for the temporary workers is 291 equivalent to the regional water demand for all fracturing activities in ND. In 2010 to 2012, the

292 domestic water requirements (2,190 Mgal) have exceeded 50\% of the total freshwater used for 293 the fracturing (4,270 Mgal) (Horner et al., 2016).

Slickwater (or water frac) is a commonly used fracturing fluid in the Bakken field.

296 Slickwater uses freshwater that is typically mixed with chemicals from the classes of friction

297 reducers, biocides, surfactants, breakers or clay-control additives. UOP from the Bakken shale 298 using slickwater is $25 \%$ higher than that using non-slickwater fluids (Geiver, 2014). However, 299 the slickwater has low viscosity ( $2-3$ centipoise) and requires higher energy to pump the 300 proppant. Gel-based fracturing fluids can also be used in tight oil formations such as the Bakken 301 shale (U.S. Department of the Interior, 2015). Gel-based fracturing fluids can be based on cross302 linked gel or hybrid cross-linked gel/slickwater. Cross-linked gel is water containing a gelling 303 agent (e.g., guar), cross-linker (e.g., Zr) and additives such as buffers, biocides, surfactants, 304 breakers, and clay controls. Compared to linear gels, cross-linked gels have a higher viscosity $305(100-1000 \mathrm{cP})$, and they are designed to improve proppant transport and achieve wider 306 fractures. Hybrid cross-linked gel/slickwater uses slickwater followed by a linear gel or cross307 linked gel during a HF process (Barati and Liang, 2014; Pearson et al., 2013; Scanlon et al., 308 2014). A typical frac system used in the Bakken shale consists of a gelling agent such as guar 309 gum $(0.45 \%)$, gel breaker $(0.02 \%)$, biocide Phosphonium salt $(0.02 \%)$, and a cross linker such as 310 borate salt $(0.08 \%$ ) (Fracfocus, 2016; Purvis D, 2015). Guar gum and its derivatives are 311 commonly used, as they are known to transport sand into the fractures in an effective manner 312 (Torres et al., 2015). 
314 Figure 4 compares the typical life cycle stages involved in water consumption for both

315 conventional oil production (COP) and UOP. COP occurs in three different stages, as follows: i)

316 the primary recovery stage that entails oil extraction using naturally occurring underground

317 pressure and occasional pumping, ii) the secondary recovery stage (water flooding) that uses

318 external energy (in the form of injecting fluids) to increase well pressure when natural pressure

319 in a well fails to recover oil, and iii) the tertiary recovery stage (enhanced oil recovery) that uses

320 thermal or steam-injection methods to recover oil (Wu and Chiu, 2011). As shown in Figure 4a,

321 the majority of freshwater consumption for COP occurs during the primary recovery stage.

322 During the secondary recovery stage, separate injection wells are drilled and the water is injected

323 into the formation to increase the oil production. As the oil production matures beyond the

324 secondary stage, the additional increase of injection water does not increase the oil production

325 because the oil is trapped in the reservoir rock due to surface tension and viscosity effects. In

326 such cases, the tertiary recovery method uses a combination of carbon dioxide $\left(\mathrm{CO}_{2}\right)$ and steam

327 to extract oil. $\mathrm{CO}_{2}$ injection reduces surface tension, while steam injection reduces viscosity, and

328 both enhance oil recovery.

330 Table 2a and Table S1 compares the oil production rates and corresponding water usage during 331 the primary, secondary, and tertiary stages for COP. As shown, the secondary stage of COP 332 entails bulk of the oil production and the highest water usage. In contrast to COP, the majority of 333 oil production in UOP occurs during the fracturing stage (i.e., primary stage) and to the lesser 334 extent during the enhanced recovery stage (Wu and Chiu, 2011). Table 2a shows also shows 335 average values for oil production rate and the water usage rate in the primary stage of UOP. 
336 Table $2 \mathrm{~b}$ ranks the individual stages of both the COP and UOP based on the following three

337 different parameters: (i) basis of oil produced, (ii) basis of water usage, and iii) basis of ratio for 338 water used for a unit of oil production.

In light of the increasing public perception of excessive freshwater demand for UOP,

341 Scanlon et al. (2014) have reported a counter-intuitive finding that freshwater requirements for 342 UOP are equivalent to, or lower than, those for COP. Using the data for UOP from the Bakken

343 Formation in western ND and eastern MT and the Eagle Ford Formation in south TX from 2009-

344 2013, Scanlon et al. (2014) have concluded that the water-consumption-to-oil-production ratio,

345 WOR (vol water/vol oil), for UOP (0.2-1.4) is within the lower range of that for COP (WOR:

346 0.1-5). Further, their study concluded that the U.S. is using more water for UOP because

347 fracturing has expanded oil production and not because the fracturing consumes more water per

348 unit of oil production. However, Lampert (2015) noted that Scanlon's study failed to account for

349 the differences in the maturity of unconventional and conventional wells, resulting in unfair

350 conclusions related to lower freshwater consumption for UOP. For example, in Scanlon's (2014)

351 study, the estimated values for WOR in COP were based on water consumption for all three

352 stages (primary, secondary, and tertiary), while the WOR for UOP considered only the primary 353 stage (Lampert, 2015).

The WOR analysis for COP in Scanlon et al. (2014) built upon a study by Wu and Chiu

356 (2011) that used experimentally determined values from the literature to calculate water 357 consumption profiles for different oil extraction technologies. Wu and Chiu (2011) have 358 estimated that 8 gallons of freshwater (2.1-5.4 gallons of make-up water and the remainder from 
recycled water) are required to extract a gallon of oil from a COP well. Figure 5 compares the

360 volume-of-water/volume-of-oil requirements for the COP and UOP technologies. As shown in

361 Figure 5, water consumption data for the COP and UOP is arranged according to the following

362 two categories: i) primary recovery stage (drilling/fracturing) and ii) secondary/tertiary recovery

363 stage (injection). Figure 5 indicates that the water consumption for the primary stage of COP is

364 relatively lower than that for UOP. Readers are advised to read the relevant literature to gain a

365 deeper insight about the controversy related to relative water footprints for UOP and COP

366 (Lampert, 2015; Scanlon et al., 2014; 2015).

\section{$368 \quad 3.3 \quad$ Flowback Water and Produced Water production (Stage IV)}

369 Figure 6 indicates that, from 2007 to 2015, the increasing number of reported brine spills in ND 370 matches with the increasing volumes of UOP from the Bakken shale. The majority of these brine 371 spills are related to the accidental release of flowback water and produced water generated from

372 the Bakken play. Flowback water is a portion of injected HF fluids that returns to surface after 373 the HF process is complete. It contains a range of fracturing chemicals (e.g., added aliphatic and 374 aromatic hydrocarbons such as solvents, biocides, and scale inhibitors) (Banerjee, 2015; U.S. 375 EPA, 2015a) and detritus of the fractured well (e.g., salts, naturally occurring radioactive 376 materials). In chemical terms, a liter of flowback water from a Bakken well contains 220,000 377 milligrams of total dissolved solids (TDS), 47,100-74,600 milligrams of sodium, 1,220 378 milligrams of carbon-rich organic matter (i.e., chemical oxygen demand) (Guerra et al., 2011), 379 traces of heavy metals, carcinogens and toxins (Auers et al., 2014; Guerra et al., 2011; Stepan et 380 al., 2010). On the contrary, produced water (fluids that are extracted together with the crude oil 381 during production) is indigenous to the deeper earths where crude oil has been buried for 
382 millions of years. Produced waters are composed of naturally occurring formation water, and can

383 contains high concentrations of total dissolved organic carbon, in addition to the organic

384 compounds typically reported in flowback waters (Vengosh et al., 2014). Both flowback and

385 produced water from the Bakken shale contains toxic metals (barium and strontium) and

386 radioactive radium along with the high levels of salinity (Gadhamshetty et al., 2015; Nelson et

387 al., 2015). Based on the available studies, representative compositions for both of these waters

388 from the Bakken shale are shown in Table 3 and Table S2. Readers are encouraged to read the

389 relevant literature about typical chemicals (originating from injected fracturing compounds and

390 natural shale formation) detected in the flowback and produced water from the contemporary

391 shales (Elsner and Hoelzer, 2016; Getzinger et al., 2015; Gordalla et al., 2013; Harkness et al.,

392 2015; Hoelzer et al., 2016; Maguire-Boyle and Barron, 2014; Orem et al., 2014; Parker et al.,

393 2014; Rogers et al., 2015). For example, produced water from Marcellus, Eagle Ford, and

394 Barnett shales are characterized with saturated (aliphatic) compounds and a small fraction of

395 aromatic, resin, and asphaltine compounds (Maguire-Boyle and Barron, 2014). Some of the

396 chemicals, such as benzene, toluene, and xylene, found in the produced water (Getzinger et al.,

397 2015) are known carcinogens and they pose environmental and health concerns.

Figure 6 considers only the brine spills that were promptly reported to the NDDH. The

400 brine spills result in an undesirable discharge of saline wastewater (TDS $=300 \mathrm{~g} / \mathrm{L}$; salinity $=47$

$401 \mathrm{~g} / \mathrm{L}$ ) into regional water bodies, especially surface waters including the Missouri River and lakes

402 (e.g., Smishek Lake near the town of Powers Lake). It is clear that the increasing number of

403 brine spills (Figure 6) threatens drinking water resources in ND (Lauer et al., 2016). However,

404 the literature suggests that the volume of the reported brine spills represent an insignificant 
405 portion of total brine generated from the Bakken shale. For example, in 2014, the volume of the

406 reported brine spills (71,000 barrels) was only $0.016 \%$ of the total brine generated $(432,000,000$

407 barrels) during the UOP in ND (Energy \& Environmental Research Center, 2015a; North Dakota

408 Department of Health, 2014a). The environmental impacts due to spills in ND are amplified if

409 the regional oil spills in the last decade (e.g., 1000 oil spills in 2011 in ND) are also taken into

410 account (Propublica, 2012). Figure 6 does not include oil spills. Readers are encouraged to read

411 the relevant information in the literature (de Santiago-Martín et al., 2015; Finkel and Law, 2011;

412 Kingston, 2002; McLaughlin et al., 2016).

413

414 Figure 7 shows the typical accidents responsible for brine spills due to UOP in ND. As

415 shown, the typical brine spill sources are related to vessel leaks, blowouts, equipment failure,

416 fires, pipeline, pump, valve, and stuffing box leaks, and truck overflows. The pipeline leaks

417 resulted in the highest number of spills (Fig. 7a) and the largest volume of spilled brine. The

418 human and ecological health impact of such spills depends upon the spill volume, spill location

419 and the specific composition of the produced and flowback water. Further, the quality of the

420 produced water and flowback changes on both the spatial (one well to another) and the temporal

421 scales (over time in the same well or one well to another) (Lyons, 2014). Regardless of the

422 specific composition, these wastewaters are not amenable to conventional treatment

423 technologies, due to their high values for chemical oxygen demand, TDS, salinity, and a suite of

424 toxic and hazardous chemicals. Currently, there is a paucity of information about the potentially

425 harmful constituents in flowback and produced water generated during UOP in ND and the

426 specific effects of brine spills on the land and water resources (EERC, 2010; Horner et al., 2016; 
427 Lauer et al., 2016). Relevant details about recent brine spills in ND are included in Section 3.4.2

428 of this study.

430 3.3.1. Chemicals involved and their toxicity

431 Table 3 provides a list of inorganic contaminants identified in produced waters and 432 flowback water in ND. The Northern Great Plains Water Consortium (NGPWC) has analyzed 433 flowback water samples from 89 different Bakken wells (Stepan et al., 2010) and reported the 434 average salinity to be high as $220,000 \mathrm{mg} / \mathrm{l}$, which is dominated by $\mathrm{NaCl}$ and contains traces of $435 \mathrm{Ca}, \mathrm{K}$ and $\mathrm{SO}_{4}{ }^{2-}$. Figure $\mathrm{S} 1$ shows the sample collection locations of Bakken oil wells where 436 flowback water data and information used in the assessment were collected. A recent report by 437 Lauer et al. (2016) has provided comprehensive details on the composition of the produced water 438 from the Bakken Formation. The produced water from the Bakken is highly saline and 439 characterized by a typical $\mathrm{Na}-\mathrm{Ca}-\mathrm{Cl}$ composition. In addition to the elevated concentrations of $440 \mathrm{Na}, \mathrm{Cl}$, and $\mathrm{Br}$, the produced water from the Bakken shale is rich in metals, metalloids, and 441 miscellaneous contaminants ( $\mathrm{Se}, \mathrm{V}, \mathrm{Sr}, \mathrm{B}, \mathrm{Mn}, \mathrm{Ni}, \mathrm{Cd}, \mathrm{Cu}, \mathrm{Zn}, \mathrm{Ba}, \mathrm{Pb}, \mathrm{Ra}$, and $\mathrm{NH}_{4}$ ) (Table 3). 442 The accidental discharge of flowback or produced water provides a potential pathway for 444 contamination of affected soils, sediments of rivers and lakes, and shallow groundwater (Vidic et 445 al., 2013) with organics, salts, metals, and other constituents shown in Table 3. The reported 446 TDS in Bakken flowback and produced water vary in the ranges of $150,000-220,000 \mathrm{mg} / \mathrm{L}$ 447 (Stepan et al., 2010) and 35000-632689 mg/L (Lauer et al., 2016; Torres et al., 2016), 448 respectively. Considering that salinity in the flowback and produced waters from Bakken shale is 449 several-fold higher than that in typical surface waters $(<1000 \mathrm{mg} / \mathrm{L})$, small discharges can 
450 degrade freshwater quality. Compared to the wastewater from the Niobrara and Marcellus shales,

451 the flowback and produced waters from the Bakken possess exceptional amounts of total

452 dissolved solids and high salinity (Abualfaraj et al., 2014; Haluszczak et al., 2013; Hayes, 2009;

453 Lester et al., 2015; Stepan et al., 2010). Health concerns arise if brine spills introduce these

454 fracturing compounds to drinking water resources at levels higher than the maximum

455 contaminant level (MCL) defined by the EPA. The MCL for sodium is $20 \mathrm{mg} / \mathrm{l}$, beyond which

456 there are increased risks for kidney damage, increased blood pressure, and irritation of the skin,

457 eyes, nose and throat.

458

459 Benzene at an MCL above $0.005 \mathrm{mg} / \mathrm{L}$ has been reported to increase cancer risks, 460 promote anemia, and decrease blood platelets in the affected people (Lenntech, 2015). 461 Consumption of toluene-contaminated water $(\mathrm{MCL}=1 \mathrm{mg} / \mathrm{L})$ increases risks for kidney and 462 liver damage. Similarly, consumption of xylene-contaminated waters (drinking water MCL $=10$ $463 \mathrm{mg} / \mathrm{L}$ ) is known to cause headaches, dizziness, lack of muscle coordination, confusion and 464 changes in the sense of balance (ATSDR, 2007). Upon inhalation, xylene irritates eyes, nose, 465 throat, and gastrointestinal tissues. Long-term inhalation exposure to xylene affects the human 466 central nervous system (U.S. EPA, 2015c). A train derailed in Lac-Mégantic carrying Bakken 467 crude oil has been reported to contain the following diverse organic compounds in varying 468 proportions: polycyclic aromatic hydrocarbons; volatile aromatic hydrocarbons such as benzene, 469 toluene, ethyl benzene and xylene; trace metals and metalloids; alcohols, biocides, surfactants, 470 acids/bases, and corrosion inhibitors (de Santiago-Martín et al., 2015). According to Globally 471 Harmonized System of classification of chemicals (1-4, 1 being the most dangerous), Bakken 472 crude oil is ranked under each category of the health effects as follows: Aspiration Hazard 
473 Category 1 (most toxic); Specific Target Organ Toxicity, Single Exposure, Category 3 (slightly

474 toxic); Specific Target Organ Toxicity, Repeated Exposure, Category 2 (moderately toxic);

475 Carcinogen, Category 1B (highly hazardous); Hazardous to the aquatic environment, long-term,

476 chronic, Category 2 (moderately toxic) (ConcocoPhillips, 2014).

477

The potential health hazards due to different constituents in flowback or produced water

479 are outlined in Table 4. The typical inorganic contaminants in the produced and flowback water

480 (shown in Table 3) belong to classes of reproductive (Golub, 2005), immunological (Berlin et al., 481 2012), and neurological toxicants (De Vries, 1996; Zatta, 2003) and endocrine disruptors

482 (Kassotis et al., 2015; Webb et al., 2014). The volatile organic compounds (e.g., benzene, 483 toluene, and xylene) and heavy metals (e.g., arsenic, cadmium and lead) in the flowback water 484 are known carcinogens that increase risks for acute myeloid leukemia, acute lymphocytic 485 leukemia, chronic lymphocytic leukemia, multiple myeloma, and non-Hodgkin lymphoma 486 (Webb et al., 2014).

As reported for the Niobrara and Marcellus shales, the brine spills in ND can also pose environmental risks (Table S2). Flowback waters from the Bakken, Marcellus and Niobrara

490 shales are all characterized by metals such as $\mathrm{Ba}, \mathrm{Sr}, \mathrm{Cd}, \mathrm{Pb}, \mathrm{Cr}$ and $\mathrm{Hg}$ that cause physiological 491 toxicity, skin and eye irritation, lung and kidney problems, and carcinogenic effects (Lenntech, 492 2015; U.S. EPA, 2016 ). Naturally occurring radioactive materials (e.g., Cs, Ra, and U) found in 493 the flowback water pose cancer risks (Lenntech, 2015; Tchobanoglous and Burton, 1991; U.S. 494 EPA, 2016 ). The endocrine disruptors reported to be found in the flowback water can cause 495 miscarriages, birth defects and impaired fertility (Kassotis et al., 2015; Webb et al., 2014). 
496 Biocides used during fracturing are reported to contain carcinogens including bronopol and 497 methylisothiazolinone (Elsner and Hoelzer, 2016; Kahrilas et al., 2014). A recent study in 2012 498 reported that residents living in Colorado within $\leq 0.5$ mile distance from unconventional gas

499 wells are at a greater risk of cancer (McKenzie et al., 2012).

\section{$501 \quad 3.4$ Management of Flowback Water and Produced Water (Stage V)}

502 Using wastewater production data from the Oil and Gas Division of the NDDMR, Horner et al. 503 (2016) compared average volumes of flowback water, produced water, and total wastewater 504 (flowback and produced) per well in the first year and the first 3 years of oil production (Figure 505 8). As shown in Table 1, on average, a Bakken well annually consumed 2.37 Mgal in 2012, 506 which corresponds to the total wastewater generated by a well in the first year of oil production 507 shown in Figure 8.

The wastewater volume generated by a Bakken well has been reported to be higher than 510 that for its counterparts (Horner et al., 2016). Further, the average wastewater production per 511 well in the Bakken play has been increasing. This trend can be attributed to the increasing 512 amount of freshwater consumption, which is primarily due to the increasing later lengths (the 513 lengths of the well bores extending horizontally within the reservoir) requiring higher numbers 514 of fracturing stages (Horner et al., 2016). Based on the first year of the oil production data in

515 Figure 8, the average volume of produced water per oil well has increased 3.5-fold from 2008 to 516 2012. The average volume of produced water in the first year of production was $0.655 \mathrm{Mgal} / \mathrm{year}$ 517 for wells completed in 2008; this value had increased to $2.31 \mathrm{Mgal} / \mathrm{year}$ by 2012. Similarly, 518 flowback water increased 1.2-fold from 2011-2012. This increasing trend in wastewater 
519 production in ND can be expected to result in relevant wastewater management challenges,

520 especially due to increasing risks for brine spills during the transportation of brine to Class II

521 injection wells. The literature suggests the following five different options for managing the

522 produced water from oil fields:

523 i) Avoid production of water onto the surface: Polymer gels can be used to block the water

524 contributed from fissures or fractures, separate water from the crude oil and gas streams

525 downhole, and reinject water into suitable formations (Igunnu and Chen, 2012).

526 ii) Inject produced water into the same formation or another formation: Produced water can be

527 injected into the same formation or another suitable formation. This option involves

528 transportation costs for moving produced water between different sites.

529 iii) Treat and discharge produced water: Use physical, chemical, or biological processes, or a 530 combination of these processes, to treat produced water and achieve the national pollutant 531 discharge elimination system (NPDES) standards (Warner et al., 2013). The treated water can 532 then be discharged into surface water bodies.

533 iv) Reuse produced water in oil and gas operations: Reuse treated water for stimulation, 534 drilling, and workover operations after appropriate treatment. Further, relevant treatment options 535 are required to reduce fouling, scaling, and biological growth on metal surfaces of drilling 536 infrastructure.

537 v) Consume in beneficial use: Reuse the treated, produced water for irrigation and for 538 consumption by cattle and other animals (Arthur et al., 2005). High levels of TDS (especially high salinity: 60,000-200,000 ppm (Stepan et al., 2010) ), 541 organics, and miscellaneous constituents (e.g., metals) in produced water from the Bakken 
542 reduce its amenability to treatment processes (Stepan et al., 2010). The NGPWC has recently

543 investigated the feasibility of reverse osmosis (RO) for treating and recycling the Bakken

544 flowback water. While RO has been reported to yield 90\% ion-removal efficiency and $70 \%$

545 water recovery, the expenditure for an off-site 1.5 MGD RO system was estimated to reach as

546 high as \$39-47 million (Stepan et al., 2010). In ND, it is currently economical to dispose the

547 wastewater into Class II injection wells (e.g., depleted oil formations and deep saline water

548 reservoirs) (Kurz et al., 2011). Nearly 400 Class II injection wells are in operation to dispose of

549 the wastewater from Bakken oil fields in ND (Horner et al., 2016; North Dakota Department of

550 Mineral Resources, 2014). The wastewaters are piped or trucked to the disposal sites where they

551 are stored in containers prior to injection into Class II wells. A study in 2010 attributed 56-84\%

552 wastewater handling costs to transportation expenditure (Cypress Energy Partners, 2015),

553 including the operational cost for fuel, labor, and insurance coverage. According to the ND

554 Industrial Commission, the cost for transporting freshwater or wastewater in ND ranges from

555 \$0.63-\$9.00 per bbl. (Stepan et al., 2010).

556

557 If produced water treatment technologies become viable in the near future, the water may

558 be treated and reused in agriculture, industries, and livestock feeding. Oil companies may take

559 initiatives to develop strategies that minimize the freshwater consumption and reduce volumes of

560 flowback water. Long-term studies are required to identify viable technologies for enabling

561 produced water reuse in the Bakken play (Stepan et al., 2010). It is important to assess

562 environmental, energy, and economic aspects of both the conventional (flocculation, coagulation,

563 sedimentation, filtration, and chemical precipitation) and advanced options (membrane process,

564 thermal distillation, and crystallization) for treating produced water (Boschee, 2014). In shale 
565 plays such as the Haynesville and the Marcellus, the oil industries have already developed 566 successful strategies for reusing wastewaters in diverse applications (Clark et al., 2013) (Auers et

567 al., 2014). Further research is required to develop similar strategies in the Bakken play. For 568 example, high salinity of produced water may prevent its reuse in certain applications (e.g., dust 569 suppression or deicing on roads), indicating the need to assess potential health and environmental 570 impacts.

571

572 3.4.1 Disclosure rule for hydraulic fracturing chemicals

573 In 1986, Congress enacted the Emergency Planning and Community Right to Know Act 574 (EPCRA) requirements for federal, state and local governments, tribes, and industry regarding 575 emergency planning and the public's right-to-know reporting on hazardous and toxic chemicals 576 (Fracfocus, 2015; U.S. EPA, 2015a). Many states including WY, PA, AR, TX, CO, NM, MN, 577 WV, ID and ND have mandated the public disclosure of HF chemicals (Fracfocus, 2015; U.S. 578 EPA, 2015a). Table 5 provides a summary of HF chemicals disclosure requirements for seven 579 states including AR, CO, LA, MT, ND, WY and PA (Department of Natural Resources: State of 580 Louisiana, 2011). ND requires the owner, operator, or service company to post, on the Fracfocus 581 chemical disclosure website within sixty days after the hydraulic fracture stimulation is 582 performed (North Dakota Industrial Commission Oil and Gas Division, 2015). This disclosure 583 rule informs the public about potential health and environmental risks caused by HF chemicals 584 (McFeeley, 2012). A study by Colborn et al. (2011) investigated 944 different chemicals, 585 including 632 compounds typically used in fracturing, and concluded the following: (a) $75 \%$ of 586 these chemicals affect the skin, eyes and other sensory organs and the respiratory and 587 gastrointestinal systems, (b) $40-50 \%$ of these chemicals can affect the brain/nervous system, the 
588 immune and cardiovascular systems and the kidneys, and (c) $37 \%$ of these chemicals can affect

589 the endocrine system and $25 \%$ cause cancer and mutations (Colborn et al., 2011). According to

590 the National Institutes of Health, handling of the fracturing compounds and contaminated

591 wastewater increases the health risks (NIH, 2014).

592

The FracFocus database (www.FracFocus.org) provides pertinent information on

594 chemical additives and the freshwater volumes used in fracturing. However, the FracFocus

595 database users can request information only for one well at a time. New organizations such as

596 SkyTruth (skytruth.org) and PackWest (pacwestcop.com) have compiled comprehensive

597 databases for all wells. For example, the SkyTruth database contains records for over 27,000

598 fracking operations across 24 different states in the U.S. and includes details for the following

599 two major categories: i) fracking operation (location, date, well depth, and volume of water) and

600 the ii) fracturing chemicals (name, quantity, and Chemical Abstract Service (CAS) number)

601 (Skytruth, 2016). Similarly, the Information Handling Services (IHS) database (www.ihs.com) is

602 comprehensive in nature and includes information related to well characteristics (depth and

603 length of the lateral) and production data (crude oil, associated gas, condensate liquid, and water)

604 (Scanlon et al., 2014). The IHS well database has been reported to account for every well in the

605 U.S., retrieving information from wells dating back to nearly 1859. In November 2014, IHS

606 acquired PacWest Consulting Partners, and the company is currently known as IHS PacWest

607 (IHS, 2016).

608

609 These databases have been widely used in several studies to assess the water resource

610 impacts due to UOP. For example, Scanlon et al. (2014) used the information from the 
611 FracFocus and IHS websites to determine the water use for HF for unconventional oil

612 development. In another study, Kondash and Vengosh (2015) used the data from the FracFocus

613 website, along with that from the U.S. EPA, state databases and the literature (e.g., a report from

614 Chesapeake Energy) to develop an integrated and comprehensive evaluation of flowback and

615 produced water generated due to unconventional oil and gas production throughout the United

616 States (Kondash and Vengosh, 2015). Based on their study, the annual freshwater consumptions

617 for unconventional oil and gas production were 17,000 Mgal and 31,000 Mgal, respectively. A

618 recent study by Horner et al. (2016) used information from the FracFocus database and the

619 NDDMR and confirmed that the freshwater consumption for UOP from the Bakken shale in ND

620 grew from $770 \mathrm{Mgal}$ in 2008 to 4,300 Mgal in 2012. Based on their analysis, they concluded that

621 the first-year wastewater volumes from UOP in ND grew in parallel, from an annual average of

622 1.135 Mgal per well in 2008 to 2.905 Mgal in 2012, surpassing the typical 4-year wastewater

623 totals for the Barnett, Denver, and Marcellus shales.

625 Because each phase of the HF process (e.g., drilling, fracturing, and wastewater 626 transportation) used to recover oil from the Bakken shale poses human health risks, it is 627 important to inform the public about the risks associated with use, transport and storage of the 628 fracturing chemicals (McFeeley, 2012). ND discloses the following information about fracturing 629 chemicals to the public: i) base fluid type and volume; ii) additive trade name, vendor, 630 concentration and function; and iii) chemical name, concentration, chemical abstract number 631 (CAS) and chemical family CAS (Table 5). However, the HF disclosure rule exempts the 632 reporting requirements when companies claim confidentiality and trade secrets about the 633 chemicals used for HF (Table 5). Generally, comprehensive knowledge about HF chemicals 
634 becomes beneficial in events during which human beings and other living organisms are exposed

635 to fracturing chemicals, resulting in medical treatment. For example, it is important for medical

636 professionals to obtain information about the type and concentration of the HF chemicals that

637 affected a patient's health (McFeeley, 2012). In an event where agricultural lands are

638 contaminated with HF chemicals (e.g., toxic metals and radioactive substances), prior knowledge

639 of the physiochemical characteristics of HF chemicals facilitates an impact assessment of the

640 affected crops and affiliated food chains (McLaughlin et al., 2016; Ridlington and Rumpler,

641 2013; Shaffer, 2001). A study by McLaughlin et al. 2016 has established that, after a spill event,

642 the interaction between fracturing fluids and produced water constituents alters the fate, transport

643 and toxicity of fracturing compounds in the affected soil. For example, the glutaraldehyde (a

644 biocide used in fracturing fluids) was found to hinder the transformation of the poly(ethylene

645 glycol) (PEG) (a surfactant) which would normally be degraded in agricultural topsoil within 71

646 days. The high salinity in the produced water was also found to inhibit the biodegradation of the

647 PEG (McLaughlin et al., 2016).

\section{$649 \quad 3.4 .2 \quad$ Brine Spills}

650 Table 6 provides the list of relevant brine spills during 2015-2016 in ND. Table 6a includes 651 information on contained brine spills (contained within the production site) and Table 6b 652 provides information on uncontained brine spills (occurred outside the production site), which 653 are all based on the reported data available in the NDDH database. However, as evident from the 654 literature, many of the reported spills lack retrospective studies that investigate the specific cause 655 for the spill and subsequent risk to the land and water resource contamination, both on the spatial 656 and temporal scales. For example, during 2001-2014, 1892 brine spills were related to pipeline 
657 leaks, and to date, only 48 of them have been further investigated to discern the specific root

658 causes and the subsequent recommendations related to the operational protocols and regulations

659 (Energy \& Environmental Research Center, 2015b).

\section{3.4.2.1 Potential groundwater contamination}

662 The contamination of aquifers due to HF chemicals can occur during their exposure to leaking of

663 oil wells and unprocessed fracturing fluids (Vengosh et al., 2014). Groundwater contamination is

664 often attributed to inadequate well structural design, well casing failure, and drilling site spills

665 (Rozell and Reaven, 2012) (Figure 7). According to a U.S. EPA survey for the period of 2000 to

666 2013, approximately 9.4 million people lived within a mile of a hydraulically fractured well, and

667 approximately 6,800 public drinking water sources were located within a mile of at least one

668 hydraulically fractured well (Kaden and Rose, 2015). A recent USGS study has indicated the

669 absence of HF impacts on shallow groundwater quality in the vicinity of the Bakken Shale

670 Formation (McMahon et al., 2015). However, the potential land resource contamination from

671 spills related to UOP can pose long-term risks to the groundwater. In this study, this potential

672 will be exemplified in case studies related to the spills in the Williston and Powder River Basin.

673 For instance, due to pipe leakage, 865,200 gallons of oil spilled over 7.3 acres of land in

674 Williams County on September 29, 2013 (Horn, 2013). Williams County is located in

675 northwestern ND and lies at the center of the Bakken oil field. On January 6, 2015, an accidental

676 pipeline leak discharged $3 \mathrm{Mgal}$ of HF fluids onto the land surface, the largest spill of its kind in

677 ND during the last decade (Jacobson, 2015). In an incident in McKenzie County, 1,260 gallons

678 of oil spilled, resulting in the contamination of an oxbow of Charbonneau Creek, which is a

679 tributary of the Yellowstone River (North Dakota Department of Health, 2015a). The 
680 groundwater impacts due to these spills are yet to be corroborated with groundwater sampling 681 and scientific experiments. Media and newspaper articles suggest an increasing number of minor 682 and major oil and brine spills in ND that have never been reported (Earthjustice, 2015; The 683 Guardian, 2015). contamination of a huge groundwater aquifer $(\sim 15,000-37,000 \mathrm{Mgal})$ in East Poplar on the Fort

687 Peck Indian Reservation in MT (Thamke and Smith, 2014). Consequently, this forced the tribal 688 government to construct a new drinking water pipeline to draw water from the Missouri River 689 (Mordick, 2014). The Bakken crude oil characteristics are similar to those of the East Poplar 690 field (Griswold, 2014). Due to similarities in crude oil handling and disposal practices, water 691 resource impacts from UOP in the Williston Basin may be anticipated as similar to those of the 692 recent East Poplar oil field incident (Griswold, 2014). These studies suggest that it is important 693 to incorporate long-term groundwater monitoring strategies and track the potential movement of 694 the HF chemicals from unconventional oil fields. A modeling study by Michie and Koch 695 suggested that it is important to extend the surface casing of Class II injection wells below the 696 bottom of drinking water aquifers to minimize contamination risks in the Williston Basin 697 (Frohlich et al., 2014; Michie and Koch, 1991). This simple and yet effective recommendation is 698 expected to minimize the aquifer contamination risks due to leaking wells by a thousand-fold 699 (Michie and Koch, 1991).

701 Table 7 provides a list of ongoing studies that investigate landscape effects and 702 environmental impacts due to oil production in the Williston Basin (USGS, 2013). For example, 
703 a USGS study is investigating the effects of brine contamination near the East Poplar oil field on 704 the Fort Peck Indian Reservation (Table 7) (Thamke and Smith, 2014). Another ongoing study is 705 investigating whether brine water originating from storage tank facilities, oil wells, brine 706 injection wells, pipelines, and impoundment pits in the oil fields contributes to groundwater 707 contamination (USGS, 2014a). As shown in Figure 7, brine spills in ND are typically attributed

708 to the infrastructure failures (e.g., vessel leak, blowout, pump leak, equipment failures) and 709 accidents (e.g., pipeline leaks, fire, tank overflow, truck overflow). The USGS aims to establish a 710 water-energy nexus, especially in the context of regional groundwater availability, and assess the 711 long-term water needs and groundwater availability for the widespread crude oil production in 712 the Bakken region. The USGS water-quality characterization studies will provide a detailed 713 understanding of current groundwater and surface quality conditions due to oil and gas 714 production from tight shales. The USGS intends to carry out diverse studies to address explicit 715 ecological effects of oil field operations on the prairie pothole region that serves as habitat for 716 native and migratory wildlife (Table 7). The USGS study "A GIS-Based Vulnerability 717 Assessment of Brine Contamination to Aquatic Resources from Oil and Gas Development in 718 Eastern Sheridan County" is designed to analyze whether the regional aquatic resources are 719 vulnerable to oil exploration and production, based on oil field parameters (age and density of oil 720 wells) and hydrogeological characteristics (surficial geology, wetland area, and length of 721 streams) (Preston et al., 2014) (Table 7). The following sections provides a summary of results 722 from the case studies related to potential ground water contamination due to brine spills in 723 Killdeer region, and near Williston and Powder River Basin in ND. 
726 for a retrospective case study in Dunn County, North Dakota, conducted near Killdeer, North

727 Dakota. This is one of the five retrospective case studies conducted by the U.S. EPA to assess the 728 potential impacts of a blowout incident, related to UOP from the Bakken shale, on drinking 729 water resources. The blowout occurred at the Franchuk 44-20 SHW well site (Franchuk well) 730 during the fifth stage of the 23-stage HF and released fracturing fluids, oil, and flowback water

731 onto the land surface and possibly into the Killdeer aquifer in September 2010. Sixteen

732 representative water quality samples were collected from 2 supply wells, 3 domestic wells, a 733 municipal well, 9 monitoring wells and a state well, during a total span of three years.

734 Specifically, the samples were collected in July 2011, October 2011, and October 2012 (U.S. 735 EPA, 2015b). The study concluded that the water samples were free of detectable methane, 736 organic compounds (except tertiary-butyl alcohol), and sulfates. Table S3a shows the 737 concentration and major chemistry of groundwater sources impacted by the Franchuk well 738 blowout in Killdeer. Location details for the samples collected near the well blowout are shown 739 in Table S3b. The authors further concluded that the measured data for the specific HF 740 contaminants were comparable to the historical data from the Killdeer aquifer and all wells 741 (except for two wells), implying that the Franchuk incident did not influence the groundwater 742 resources. Based on this study, the Franchuk 44-20 SWH well blowout was the potential source 743 for contamination in only two of sixteen wells considered. However, long-term studies may be 744 required to monitor the true impact of such incidents.

746 3.4.2.1.2 Quality of shallow groundwater near the Bakken Formation Production Area: As a part

747 of the USGS investigation of ground water availability in the Williston and Powder River 
748 Basins, a study was designed by McMahon et al. (2015) to study the effects of the UOP,

749 especially from surface spills and subsurface leaks (imperfectly cemented wells) on the regional

750 ground water quality. While the study did not include any specific details about sources of

751 surface spills and subsurface leaks, they have collected the water samples from 30 randomly

752 distributed domestic ground wells in the upper Fort Union formation at the median distance of

$7534.6 \mathrm{~km}$ from the nearby oil and gas wells. The study area included the wells in the Williston

754 Basin in western North Dakota including the southeastern extent of the Bakken Formation and

755 northeastern Montana (McMahon et al., 2015). The 100,600 $\mathrm{km}^{2}$ study area in the Upper Fort

756 Union Formation was divided into 30 equal-area and a domestic well from each area was

757 sampled from August through September, 2013. Unlike the case Study in Killdeer, ND,

758 inorganic and organic chemical concentrations of the samples analyzed in this study indicated no

759 potential effect of oil and gas HF activities on the groundwater. However, it was cautioned that

760 their results be considered in the context of ground water age. For example, the majority of

761 groundwater used for domestic supply in the upper Fort Union Formation is based on pre-1950s

762 in age, and the domestic wells used in their study are not well suited for detecting contamination

763 due to recent spills related to the UOP in ND (McMahon et al., 2015). Based on the slow

764 groundwater velocities in the Upper Fort Union Formation, contaminants from the wells will be

765 less than $0.5 \mathrm{~km}$ from their source, while the median distance between the oil and gas wells and

766 water sampled in their study is more than $4.6 \mathrm{~km}$ (McMahon et al., 2015). Their study suggests

767 that further ground water monitoring should be done closer to the UOP activities. Table 4 shows

768 the concentration and major chemistry, and traces metals in the ground near oil and gas well in

769 the upper Fort Union Formation of the Bakken (McMahon et al., 2015). 


\subsubsection{Surface Water Contamination due to Brine Spills}

772 The potential pathways for surface water contamination due to crude oil production from the

773 Bakken shale can be attributed to accidental spills or leakages during crude oil storage, mixing

774 and pumping of fracturing fluids, chemicals and wastewater, transportation of crude oil and

775 produced water, and injection of produced water into Class II injection wells (Figure 7). The

776 magnitude and the impact of spills on the water resources depend upon the nature of the spills

777 (quantity and chemical composition of spilled liquid) and the transport and toxicity

778 characteristics of the chemicals. Further, discharge of unprocessed produced and flowback water

779 can contaminate the receiving surface water bodies. For instance, the effluent from the brine

780 treatment facility for Marcellus shale produced water in western Pennsylvania contained higher

781 concentrations of chloride, bromide, strontium, and radium than the threshold regulations

782 (Warner et al., 2013). Another study investigating the contribution of HF wastewater from the

783 Marcellus Shale and the Fayetteville Shale to river waters found that HF wastewater as low as

$7840.01 \%$ resulted in significant alterations to disinfection byproducts formation upon chlorination,

785 chloramination, or ozonation (Parker et al., 2014).

787 It is clear that a potential brine spill in the Bakken region could contaminate the soil in 788 affected agricultural fields with salts, heavy metals, and hydrocarbons (Rebhun, 2004), hindering 789 the growth of the affected crops by limiting their ability to consume water (McLaughlin et al., 790 2016; USDA, 1998). In the study by Lauer et al. (2016), it was concluded that brine spills can 791 contaminate the surface water (or soil) with elevated levels of inorganic contamination that can 792 last as long as 4 years following the spill events (Lauer et al., 2016). The subsequent sections 793 provide the details of three retrospective case studies involving recent brine spills in ND. All 
794 three of the brine spill events were investigated by Lauer et al. (2016) to study their impacts on

795 the receiving surface water sources. Relevant samples were collected to analyze the following:

796 (1) major anions, (2) major cations, (3) trace metals, (4) strontium isotopes, (5) oxygen and

797 hydrogen isotopes, (6) alkalinity, (7) dissolved organic carbon, and (8) dissolved radium (Lauer 798 et al., 2016).

799

800 3.4.2.2.1 Bear Den Bay Spill and Blacktail Creek Spill: The Bear Den Bay spill and the Blacktail

801 Creek spills represent the two largest brine spill events in the history of ND. In July 2014, an 802 underground pipeline leaked and discharged nearly 24000 barrels (1 Mgal) of brine into a ravine 803 and into Bear Den Bay (approximately $0.4 \mathrm{~km}$ upstream of the drinking water intake in Lake 804 Sakakawea) (Lauer et al., 2016). Another spill occurred in Blacktail Creek in January 2015, 805 which was also attributed to a pipeline leak that released 70000 barrels (3 Mgal) of brine into 806 Blacktail Creek that flows into Little Muddy River, which is a tributary of the Missouri River. 807 The GPS coordinates for the spill sites are shown in Figure S2. In both spill events, the chemical 808 composition of the spill water samples showed that the impacted sites were potentially mixed 809 with the brine that originated from the Bakken shale, as evident from the values for $\mathrm{Br} / \mathrm{Cl}, \mathrm{B} / \mathrm{Cl}$, $810 \mathrm{Sr} / \mathrm{Cl}$, and $\mathrm{Li} / \mathrm{Cl}$ (Figure S3) ratios that exceeded the values for the background water. The 811 sample analysis further indicated that the values for the $\mathrm{Li} / \mathrm{Cl}, \mathrm{B} / \mathrm{Cl}$, and $\mathrm{Sr} / \mathrm{Cl}$ in the spill waters 812 were comparable to those brines, indicating the potential of impact due to the spills. As shown in

813 Table $8 \mathrm{a}$ and $8 \mathrm{~b}$, the defined background waters in the study were relatively saline, which is 814 consistent with the findings from other literature sources (Lauer et al., 2016). It was concluded 815 that the high salinity in the spill waters could not confirm that contamination was due to the brine 816 spills. The study therefore recommended using strontium ( $\mathrm{Sr}$ ) isotopes as an independent tracer 817 for the origin of the spills. They reasoned that, unlike the ionic ratios $(\mathrm{Br} / \mathrm{Cl})$ that are affected by 
818 salt dissolution and differ from the expected Bakken brine composition, the $\mathrm{Sr}$ isotope ratios

819 remain unaffected by the precipitation and the dissolution of secondary minerals (Table 8a and $8208 b)$.

Based on the analysis by Lauer et al. (2016), the magnitude of the contamination for the 823 two sites depends upon the relative mixing proportions of the brine and the impacted surface 824 waters. To study the effect of evaporation on the spill site, specifically the precipitation of 825 relevant contaminants, they simulated the evaporation of the spill water and the saturation index 826 (SI = $\log$ [Ionic-activity-product/Apparent-equilibrium-solubility-product]) of relevant minerals 827 using the Program for Speciation, Batch-Reaction, One-Dimensional Transport, and Inverse 828 Geochemical Calculations (PHREEQC) software and showed that calcite and barite minerals can 829 be expected to be supersaturated in the two spill sites. They concluded that the spill sites 830 subjected to extensive evaporation would result in supersaturation and secondary mineral 831 precipitation and subsequent soil salinization. There were 1.8- to 3.6-fold increments in Ra 832 activities and 1 -fold lower ${ }^{228} \mathrm{Ra} /{ }^{226} \mathrm{Ra}$ activity ratios in soil samples collected at the Bear Den 833 Bay spill site (Table 8a). In the Blacktail Creek spill, Ra activities were 190-fold lower in the 834 spill water compared to the brines (Table 8a). Such variation in radioactivity and isotopic ratios 835 can provide useful information in the study of the potential impacts of the spills. These 836 retrospective case studies suggest that brine spills with sizes equivalent to those of the Bear Den 837 Bay spill and the Blacktail Creek spill can likely result in surface water contamination in ND. 
840 300-barrel (12,680 gallons) brine spills occurred in February 2011 and in July 2011. These spills

841 were comparatively smaller than the spills discussed in section 3.5.2.2.1. These spills occurred at

842 a distance from water sources, and it is likely that these spills would undergo evaporation and

843 result in the precipitation of minerals. In the study by Lauer et al. (2016), they found that the

844 chemical composition of the spill water was different from that of Bakken brines mixed with

845 background saline water. However, they attributed the distinctively low $\mathrm{Br} / \mathrm{Cl}$ of the Bottineau

846 County spill to the evaporation losses that resulted in secondary mineral precipitation and 847 redissolution.

Based on the above retrospective case studies investigated by Lauer et al. (2016), surface

850 waters impacted by brine spills can result in surface water contamination with trace metals. Their

851 results suggest that the metal concentrations in the impacted spill site can reach 1 to 2 orders of

852 magnitude higher than the average concentrations reported in the background surface water.

853 Their results indicate that brine spills can result in raised levels of salts and trace elements at the

854 spill sites and that elevated contaminant levels, especially for the inorganic contaminants, can

855 persist for as long as 4 years. Lauer et al. (2016) recommended future research to evaluate

856 additional spill sites, analyze organic and inorganic contaminants, assess the downstream areas

857 of spill sites for possible risk, and perform a comprehensive assessment of long-term ecological 858 and possible human health impacts (Lauer et al., 2016).

8603.5 ND Water Regulations - hydraulic fracturing impacts on regional water resources The 861 North Dakota Industrial Commission (NDIC) oil and gas division is primarily responsible for 
862 minimizing environmental impacts due to oil and gas drilling and production in ND. As 863 described in the NDIC website, the NDIC strives to minimize waste during drilling and 864 production, enhance economic recovery, and protect the rights of the landowner, producer, 865 royalty owner and the public. The NDDH environmental health section (EHS) is responsible for 866 monitoring the quality of air, land and water resources. The NDDH water quality division 867 monitors water resource impacts due to the oil industry. It ensures water quality protection 868 through the processes of permitting, inspection, sampling, and analytical and monitoring 869 services, enabling the oil industry to adhere to the regulations prescribed under the U.S. EPA's 870 Clean Water Act and the Safe Drinking Water Act (SDWA). The NDDH water quality division 871 monitors the effects of oil drilling and pollution on water resources under four different 872 categories including surface water quality and management, water quality special projects, 873 groundwater protection, and wastewater facilities and permits. The specific ND water quality 874 standards are described in ND administrative code (NDAC) Article 33-16. For example, 875 according to NDAC 33-16-02.1-11, the unprocessed wastewater from oil exploration cannot be 876 directly discharged into ND state water. According to Water Code Section 13050-13051, the 877 state water includes surface, ground and saline water within the ND boundaries. NDAC 43-02878 03-19.3 mentions that HF wastewaters should be processed, stored and disposed of without 879 affecting ND water bodies. ND uses the U.S. code 33 USC 1342 and 40 Code of Federal 880 Regulations (CFR) 122 to establish a wastewater facility/permits program under the NPDES to 881 regulate the discharge of oil waste into ND waters. However, a permit is not required to 882 discharge the storm water runoff from oil and gas exploration activities, if the runoff is 883 composed of water flows that are not exposed to oil waste. If the runoff is likely to pick up 
884 undesirable oil pollutants and transport them to ND water, then an NPDES permit is required to 885 meet 40 CFR 122.26(b)(14)(i)-(xi) Code of Federal Regulations.

The 40 CFR PART 435 subpart $C$ and subpart E regulations of the U.S. EPA oil and gas extraction wastewater effluent limitation guidelines and standards are applicable to waste

889 discharges from the exploration, drilling, treatment and completion activities for UOP. There are

890 specific pretreatment requirements described by the U.S. EPA for indirect dischargers that treat

891 wastewater before discharging into Publicly Owned Treatment Works (POTWs) (Natural gas

892 extraction portal, 2015). However, discharges from POTWs are subject to 40 CFR PART 437

893 Code of Federal Regulations.

A state-approved permit (NDAC 43-02-05) and U.S. EPA federal regulations (SDWA 896 guidelines for underground injection control (UIC)) are required for the injection of brine, 897 produced and flowback water discharge from the Bakken oil fields into Class II injection wells. 898 ND works closely with the U.S. EPA to implement SDWA, depending upon geological 899 conditions, and facilitates the protection of drinking water aquifers.

\section{$901 \quad 4.0 \quad$ Transportation Hazards and Corrosion Problems}

902 The Bakken oil produced in ND is transported to refineries by railcar, truck and barge (New 903 York State Department of Health, 2014). The high volatility of the Bakken oil poses unique fire 904 hazards during its transportation. In 2013-2014, three major Bakken oil spills were reported to 905 have caused fire accidents; two of these three incidents were related to rail cars, and the third 906 incident was due to barge transport. The Lac-Mégantic Quebec railway fire incident resulted in 
907 soil and river water contamination and caused forty-seven human deaths. The Louisiana barge 908 incident in 2014 resulted in accidental discharge of 30,000 gallons of crude oil into the 909 Mississippi River, resulting in an abrupt cessation of drinking water supply (New York State 910 Department of Health, 2014). The NDDH website provides a list of the major truck incidents 911 related to crude oil spills in ND (North Dakota Department of Health, 2015c).

913 The shipping of Bakken oil by rail has increased from $30 \%$ in 2011 to $55 \%$ in 2014. The

914 increasing use of railways for oil transport in ND has been attributed to the lack of adequate 915 pipeline infrastructure for crude oil (Frittelli et al., 2014). Compared to gasoline, the Bakken 916 crude oil is highly volatile due to its low flash point $\left(32{ }^{\mathrm{O}} \mathrm{F}\right)$ and high vapor pressure $(7-15 \mathrm{psi})$.

917 The high levels of dissolved methane $\left(\mathrm{CH}_{4}\right)$ in the Bakken oil tend to bubble out of the liquid and 918 exist in the vapor phase above the liquid surface. The United States Department of 919 Transportation (USDOT) classifies the Bakken crude oil as a Class 3 flammable liquid with 920 Packing Group 1 (PG 1), categorizing the Bakken crude oil as the most dangerous fluid in the PG 9211 category. The increasing rates of ND railcar incidents have been attributed to increased crude 922 oil volume being transported in DOT-111 rail cars (New York State Department of Health, 923 2014). The natural gas liquid (NGL) in the Bakken crude oil has also been reported to increase 924 the risks to the carrying pipelines. The NGL in the crude oil results in the emission of flammable 925 gases in the case of a leaking crude oil pipeline. Ruptured oil pipelines represent $16 \%$ of pipeline 926 failures but account for $80 \%$ of fatality incidents (Hill et al., 1993).

927

928 The steel pipelines carrying crude oil or produced water are vulnerable to corrosion. The 929 high total dissolved solids (notably, chloride and sulfate) in the produced water have often been 
930 reported to result in the failure of the corrosion inhibitors (Roscoe Moss Company, 1990). The

931 high salinity in the produced water can also result in the pitting corrosion of the exposed

932 pipelines, increasing the risks for groundwater contamination. Higher levels of hydrogen sulfide

$933\left(\mathrm{H}_{2} \mathrm{~S}\right)(\sim 1,200 \mathrm{ppm})$ in the Bakken oil (Andrews, 2014) imply that the corresponding oil

934 pipelines are prone to sulfide stress corrosion (Kemp, 2013). Media reports have highlighted a

935 series of pipeline accidents in the Bakken region during the past five years. For example, a recent

936 pipeline accident introduced nearly $3 \mathrm{Mgal}$ of produced water from the Bakken shale into the

937 Missouri River (Dawson, 2015). The corrosion deposits (e.g., goethite ( $\alpha$-FeOOH) (Gerke et al.,

938 2010) typically found on interior surfaces of pipes can adsorb and accumulate heavy metals and

939 radioactive constituents present in produced water. A pipeline accident can therefore release

940 significant amounts of fracturing contaminants into regional land and surface waters (Gerke et

941 al., 2013). The oxidizing biocides such as N-bromosuccinimide (NBS) used to arrest biological

942 growth can promote corrosion of pipelines carrying produced water (Kahrilas et al., 2014). A

943 detailed set of R\&D studies may be required to quantify corrosion and material degradation

944 aspects of pipelines exposed to the oil or produced water from the Bakken shale.

945

$946 \quad 5.0 \quad$ Conclusion

947 This study reviews the major risks to water resources (WR) due to UOP from the ND

948 Bakken shale. The UOP from the ND Bakken shale results in following unique WR impacts

949 compared to other plays in North America: (i) water demand due to large volumes of

950 maintenance water to avoid salinity buildup; (ii) excessive domestic water consumption due to

951 temporary oilfield workers; (iii) unusual levels of salinity in produced water that minimize its

952 recycling options; (iv) intense pressure of the existing infrastructure (trucking and piping) to 
953 transport produced water from oil wells to deep injection wells; (v) large brine spills due to truck

954 accidents and pipeline breaks during transport of produced water; (vi) high flammability of

955 Bakken oil that poses explosion risks. Other potential WR risks in ND and the recommended

956 solutions are outlined in Table 9. The first WR risk is the water stress that can be developed due

957 to excessive withdrawals of freshwater from arid regions, especially during drought periods.

958 Potential limitation of freshwater resources for UOP can be minimized by developing alternative

959 WR such as brackish ground water or produced water, marginal waters (e.g., acid mine drainage

960 from abandoned coalmines that is unfit for domestic and agricultural use), or alternate liquids

961 (e.g., gel) for fracturing. The second risk is related to WR contamination due to the migration of

962 fracturing fluids or saline water due to well casing failure or inadequate well structural design,

963 which can be mitigated with well-integrity tests and engineering controls. The brine spills due to

964 the infrastructure failure (e.g., pipeline leaks) can be minimized by recycling produced water for

965 UOP and reducing the need to transport water to injection wells (Table 8).A third risk is related

966 to the spills sites in ND that accumulated a range of toxic and radioactive elements, implying that

967 the spill events affect the WR impacts for several years after they occur. A series of retrospective

968 studies are required to evaluate WR impacts in the spill sites, especially near the oil wells, rather

969 than the aquifers and surface water away from the contamination. A detailed investigation of

970 hydrology and hydrogeology and water chemistry using the recently developed geochemical and

971 isotopic tracers (e.g., ${ }^{87} \mathrm{Sr} /{ }^{86} \mathrm{Sr}$ ) are required at multiple spill sites to confirm or refute the

972 evidence for WR contamination due to UOP in ND.

973

974 Acknowledgements 
975 This study was in part supported by the CBET division, NSF (Award\#1454102). The funding

976 sources had no involvement in design of this study; in the collection, analysis and interpretation

977 of data; in the writing of the report; and in the decision to submit the paper for publication. We

978 thank anonymous reviewers for their insightful comments and suggestions. We are thankful to

979 Scott Besmer (KLJ) for providing a detailed insight on the produced water management practices

980 in ND.

981

982 List of Figures

983 Figure 1. Potential water resource impacts due to the consumptive and non-consumptive water 984 use for crude oil production from the Bakken shale (Hydraulic fracturing water lifecycle 985 information adapted from U.S. EPA (2015), Chemical mixing and well injection sequence 986 adapted from (Jiang et al., 2014).

987 Figure 2. Topographical map showing Williston basin boundary (highlighted in blue), prairie 988 pothole regions (highlighted in yellow), Bakken formation boundary (highlighted in red), and oil 989 and gas wells (highlighted in black) (With permission from (U.S. Geological Survey, 2015)).

990 Figure 3. Comparison of drilling productivity for Bakken shale with Permian, Marcellus, and 991 Niobrara shales: a) Total crude oil production (bbl/d), b) Total natural gas production (bbl/d), c) 992 Rig count, and d) oil production per rig (bbl/d/rig) (Adapted from (U.S. EIA, 2015))

993 Figure 4. Conventional Vs unconventional oil extraction process a) Schematic of Convention oil 994 extraction b) Schematic of Unconventional oil extraction

995 Figure 5. Comparison of water injection and consumption for three different oil recovery stages 996 throughout the lifecycle of petroleum reservoirs. a) Water consumption for COP b) Water 997 consumption for UOP (Adapted from Lampert (2015), Wu and Chiu (2011)

998 Figure 6. Parallel rise of annual Bakken oil production and number of spills in North Dakota 999 from 2007 to 2014. Data compiled from North Dakota Department of Health and Lauer et al., $1000 \quad$ (2016)

1001 Figure 7. The distribution of brine spills sources in North Dakota based on (a) the number of 1002 spills and, (b) the volume of spilled brine. Data were compiled from North Dakota Department 1003 of Health: Environmental Releases \& Investigations c) Brine spills volumes in North Dakota 1004 since 2007. Data were compiled from North Dakota Department of Health: Environmental 1005 Releases \& Investigations. (https://www.ndhealth.gov/WQ/GW/spills.htm) and Lauer et al., 1006 (2016) 
1007 Figure 8. Average Flowback and Produced Water per Well in the First 1 and 3 Years of 1008 Production. Adapted from Horner et al., (2016)

1009 Figure S1. Locations of Bakken oil wells where frac flowback data and information were used in 1010 the assessment. (Adapted from Stepan et al., (2010))

1011 Figure S2. A) Specific locations of collected spillwater and spill sediments in the Bear Den Bay

1012 Spill site. Soil/sediment samples were collected at ND102A, ND102B, ND102C, ND102D,

1013 ND102E, and ND103Water samples were collected at ND102 and ND103.Lake Sakakawea is

1014 located downstream of the spill B) Specific locations of collected spill water and spill sediments

1015 in the Blacktail Creek Spill site. Soil/sediment samples were collected at ND125, ND124,

1016 ND123, ND123A, ND123B, and ND122Water samples were collected at ND125, ND124,

1017 ND123, ND126, and ND122 (Lauer et al., (2016))

1018 Figure S3. Bromide, lithium, strontium, and boron vs. chloride in water samples, sorted by water versus chloride concentrations (log scale) in Bakken produced waters, spill waters, and

1020 background waters. Spill waters were defined on the basis of their chemical composition and resemblance to the Bakken brines (type A spills refers to Bear Den Bay Spill and Blacktail Creek

1022

1023 Spill ) relative to chemical fractionation induced from recycling of the Bakken brines (type B spills refers to Bottineau County Spill) (Adapted from Lauer et al., (2016))

1024

\section{List of Tables}

Table 1. Annual Total Water Consumption for Hydraulic Fracturing in the North Dakota Bakken Play (Adapted from Horner et. al., (2016))

1028 Table 2a. Comparison of COP and UOP oil production and water used

1029 Table 2b. Ranking of COP and UOP based on oil produced and water used in different stages

1030 Table 3. Major Chemistry, Isotopic Ratios and Trace Metals of Produced water (Adapted from 1031 Lauer et al., (2016)) and Flowback water in Bakken (Adapted from Stepan et al., (2010))

1032 Table 4. Major Chemistry, and Trace Metals in the ground water at the median distance of 4.6 $1033 \mathrm{~km}$ from the nearest oil and gas well in the upper Fort Union Formation of the Bakken (Adapted

1034 from McMahon et al., (2015), Tchobanoglous and Burton, (1991))

1035 Table 5: Comparison of State Hydraulic Fracturing Chemical Disclosure Regulations in 1036 Arkansas, Colorado, Louisiana, Montana, Wyoming, North Dakota and Pennsylvania (Adapted 1037 from (Department of Natural Resources: State of Louisiana, 2011))

1038 Table 6a. Representative, reported brine spills that occurred between 2015-2016 in North Dakota 1039 (Contained spills)

1040 Table 6b. Representative, reported brine spills that occurred between 2015-2016 in North Dakota 1041 (Uncontained spills) 
1042 Table 7: U.S. Geological Survey, recent and ongoing studies in the Williston Basin. November

10432013 (Adapted from (USGS, 2013))

1044 Table 8a. Major Chemistry, Isotopic Ratios and Trace Metals of the impacted surface water due 1045 to the Bear Den Bay Spill and Blacktail Creek Spills related to the unconventional oil production 1046 from the Bakken shale (Adapted from Lauer et al., (2016))

1047 Table 8b. Major Chemistry, Isotopic Ratios and Trace Metals of the impacted surface water due 1048 to the Bottineau County Spill related to the unconventional oil production from the Bakken shale 1049 (Adapted from Lauer et al., (2016))

1050 Table 9. Recommendations for possible water resource challenges in ND Bakken shale

1051 Table S1. Comparison of COP and UOP oil production and water used

1052 Table S2. Major Chemistry and Trace Metals of produced water in Marcellus and Niobrara 1053 (Adapted from (Abualfaraj et al., (2014), Lester et al., (2015), Hayes (2009), Haluszczak et al., 1054 (2013), Lenntech, 2015))

1055 Table S3a. Major Chemistry of ground water sources impacted by Franchuk well blowout in 1056 Killdeer, ND.(Adapted from U.S. EPA (2015))

1057 Table S3b. Locations details for the samples collected near the Franchuk 44-20 SWH well 1058 blowout (Adapted from U.S. EPA (2015))

1059

1060

1061

1062

1063

1064

1065

1066

1067

1068

1069

1070

1071

1072

1073

1074

1075

1076

1077

1078

1079

1080

\section{References}

Abualfaraj, N., Gurian, P.L.,Olson, M.S., 2014. Characterization of Marcellus shale flowback water. Environmental Engineering Science 31(9), 514-524.

Andrews, A. 2014. Crude Oil Properties Relevant to Rail Transport Safety: In Brief https://www.google.com/url?sa=t\&rct=j\&q=\&esrc=s\&source=web\&cd=1\&ved=0ahUKE wizhP6t3rjJAhXErB4KHTFWCzIQFggdMAA\&url=https\%3A\%2F\%2Fwww.hsdl.org\% 2F\%3Fview\%26did\%3D751042\&usg=AFQjCNGXPbr4eCVUgzA91W49V0s5TnsI2g\&c $\mathrm{ad}=\mathrm{rja}$. (accessed November, 2015).

Arthur, J.D., Langhus, B.G.,Patel, C., 2005. Technical summary of oil \& gas produced water treatment technologies. All Consulting, LLC, Tulsa, OK.

ATSDR. 2007. Public Health Statement Xylene. http://www.atsdr.cdc.gov/ToxProfiles/tp71-c1b.pdf. (accessed August, 2016).

Auers, J.R., Couture, R.M.,Sutton, D.L. 2014. The North Dakota Petroleum Council Study on Bakken Crude Properties. https://www.ndoil.org/image/cache/Bakken_Quality_Report.pdf. (accessed July, 2016).

Bakken-Lodgepole, T., 2008. Assessment of Undiscovered Oil Resources in the DevonianMississippian Bakken Formation, Williston Basin Province, Montana and North Dakota, 2008.

Banerjee, N. 2015. Fracking Companies Keep 10\% of Chemicals Secret, EPA Says. http://insideclimatenews.org/news/31032015/fracking-companies-keep-10-chemicalssecret-epa-says. (accessed December, 2015). 
1081

1082

1083

1084

1085

1086

1087

1088

1089

1090

1091

1092

1093

1094

1095

1096

1097

1098

1099

1100

1101

1102

1103

1104

1105

1106

1107

1108

1109

1110

1111

1112

1113

1114

1115

1116

1117

1118

1119

1120

1121

1122

1123

1124

1125

Barati, R.,Liang, J.T., 2014. A review of fracturing fluid systems used for hydraulic fracturing of oil and gas wells. Journal of Applied Polymer Science 131(16).

Berlin, A., Dean, J., Draper, M., Smith, E.,Spreafico, F.,2012. Immunotoxicology: Proceedings of the International Seminar on the Immunological System as a Target for Toxic Damage_-Present Status, Open Problems and Future Perspectives, Springer Science \& Business Media.

Boschee, P., 2014. Produced and Flowback Water Recycling and Reuse: Economics, Limitations, and Technology. Oil and Gas Facilities 3(01), 16-21.

Bradley, R.L., Jr. 2014. Rail Transport: 99.9\% Safe. http://www.wilsoncountynews.com/article.php?id=58421\&n=commentaries-railtransport-safe. (accessed December, 2015).

Clark, C.E., Horner, R.M.,Harto, C.B., 2013. Life cycle water consumption for shale gas and conventional natural gas. Environmental science \& technology 47(20), 11829-11836.

Colborn, T., Kwiatkowski, C., Schultz, K.,Bachran, M., 2011. Natural gas operations from a public health perspective. Human and ecological risk assessment: An International Journal 17(5), 1039-1056.

ConcocoPhillips. 2014. Safety Data Sheet http://www.conocophillips.com/sustainabledevelopment/Documents/2014.05.30\%20825378\%20Bakken\%20Crude\%20Oil,\%20Swe et.pdf. (accessed August, 2016).

Cypress Energy Partners. 2015. Water and Environmental Services. http://cypressenergy.com/our-industries/water-and-environmental-services/. (accessed November, 2015).

Dawson, C. 2015. Leak of Oil-Well Wastewater Taints River in North Dakota. http://www.wsj.com/articles/bakken-shale-oil-well-wastewater-leak-taints-river-in-northdakota-1421977006. (accessed November, 2015).

de Santiago-Martín, A., Guesdon, G., Díaz-Sanz, J.,Galvez-Cloutier, R., 2015. Oil Spill in LacMégantic, Canada: Environmental Monitoring and Remediation. Int J Water Wastewater Treat 2(1).

De Vries, J.,1996. Food safety and toxicity, CRC press.

Department of Natural Resources: State of Louisiana. 2011. Comparison of State Hydraulic Fracturing Chemical Disclosure Regulations. http://dnr.louisiana.gov/assets/docs/conservation/12.StateHFRuleComparison.pdf. (accessed December, 2015).

Earthjustice. 2015. North Dakota And Fracking. Earthjustice. http://earthjustice.org/features/north-dakota-and-fracking. (accessed July, 2015).

EERC. 2010. Subtask 1.2 - Evaluation of key factors affecting successful oil production in the Bakken formation, North Dakota. https://www.undeerc.org/bakken/pdfs/JAS_Bakken_May10.pdf. (accessed August, 2016).

Elsner, M.,Hoelzer, K., 2016. Quantitative Survey and Structural Classification of Hydraulic Fracturing Chemicals Reported in Unconventional Gas Production. Environmental science \& technology 50(7), 3290-3314.

Energy \& Environmental Research Center. 2015a. Spils-Clean-up-Primer-2015. http://www.northdakotaoilcan.com/wp-content/uploads/2015/10/BPOP-Spils-Clean-upPrimer-2015-1.pdf. (accessed October, 2016). 
1126

1127

1128

1129

1130

1131

1132

1133

1134

1135

1136

1137

1138

1139

1140

1141

1142

1143

1144

1145

1146

1147

1148

1149

1150

1151

1152

1153

1154

1155

1156

1157

1158

1159

1160

1161

1162

1163

1164

1165

1166

1167

1168

1169

1170

Energy \& Environmental Research Center. 2015b. Liquids Gathering Pipelines: A Comprehensive Analysis. https://www.undeerc.org/bakken/pdfs/EERC\%20Gathering\%20Pipeline\%20Study\%20Fi nal\%20Dec15.pdf. (accessed June, 2016).

Entrekin, S., Evans-White, M., Johnson, B.,Hagenbuch, E., 2011. Rapid expansion of natural gas development poses a threat to surface waters. Frontiers in Ecology and the Environment 9(9), 503-511.

Federman, A. 2014. Hazardous Cargo: Shipping Highly Flammable Bakken Crude Oil by Rail. http://www.earthisland.org/journal/index.php/eij/article/warning_highly_flammable/. (accessed November, 2015).

Finkel, M.L.,Law, A., 2011. The rush to drill for natural gas: a public health cautionary tale. American Journal of Public Health 101(5), 784-785.

Fracfocus. 2015. Chemicals \& Public Disclosure. https://fracfocus.org/chemical-use/chemicalspublic-disclosure.

Fracfocus. 2016. Frac Focus Chemical Disclosure Registry. https://fracfocusdata.org/DisclosureSearch/Search.aspx. (accessed August, 2016).

Frittelli, J., Parfomak, P.W., Ramseur, J.L., Andrews, A., Pirog, R.,Ratner, M., 2014. US rail transportation of crude oil: Background and issues for congress. CRS report, Washington: Congressional Research Service.

Frohlich, C., Walter, J.,Gale, J., 2014. Induced Seismicity in the Bakken: Much Ado about Almost Nothing. AGU Fall Meeting Abstracts 1, 4436.

Gadhamshetty, V., Shrestha, N., Chilkoor, G.,Reddy, B.J., 2015. Hydraulic Fracturing: Environmental Issues. Drogos, D.L. (ed), American Chemical Society, Washington, DC.

Gaswirth, S.B., Marra, K.R., Cook, T.A., Charpentier, R.R., Gautier, D.L., Higley, D.K., Klett, T.R., Lewan, M.D., Lillis, P.G.,Schenk, C.J., 2013. Assessment of undiscovered oil resources in the bakken and three forks formations, Williston Basin Province, Montana, North Dakota, and South Dakota, 2013. US Geological Survey Fact Sheet 3013(4).

Geiver, L. 2014. The Slickwater Story. http://thebakken.com/articles/711/the-slickwater-story. (accessed August, 2016).

Gerke, T.L., Little, B.J., Luxton, T.P., Scheckel, K.G.,Maynard, J.B., 2013. Strontium concentrations in corrosion products from residential drinking water distribution systems. Environmental science \& technology 47(10), 5171-5177.

Gerke, T.L., Scheckel, K.G.,Maynard, J.B., 2010. Speciation and distribution of vanadium in drinking water iron pipe corrosion by-products. Science of the Total Environment 408(23), 5845-5853.

Getzinger, G.J., O’Connor, M.P., Hoelzer, K., Drollette, B.D., Karatum, O., Deshusses, M.A., Ferguson, P.L., Elsner, M.,Plata, D.L., 2015. Natural Gas Residual Fluids: Sources, Endpoints, and Organic Chemical Composition after Centralized Waste Treatment in Pennsylvania. Environmental science \& technology 49(14), 8347-8355.

Golub, M.S.,2005. Metals, fertility, and reproductive toxicity, CRC Press.

Gordalla, B.C., Ewers, U.,Frimmel, F.H., 2013. Hydraulic fracturing: a toxicological threat for groundwater and drinking-water? Environmental earth sciences 70(8), 3875-3893.

Gordon, D.,Garner, K. 2014. Underestimating Oil and Water Challenges in the Northern Great Plains. http://carnegieendowment.org/2014/08/12/underestimating-oil-and-waterchallenges-in-northern-great-plains. (accessed December, 2015). 
1171

1172

1173

1174

1175

1176

1177

1178

1179

1180

1181

1182

1183

1184

1185

1186

1187

1188

1189

1190

1191

1192

1193

1194

1195

1196

1197

1198

1199

1200

1201

1202

1203

1204

1205

1206

1207

1208

1209

1210

1211

1212

1213

1214

1215

1216

Griswold, M. 2014. Fracking in the Bakken threatens Missouri River watershed health. http://switchboard.nrdc.org/blogs/mgriswold/fracking_in_the_bakken_continu.html. (accessed November, 2015).

Guerra, K., Dahm, K.,Dundorf, S.,2011. Oil and gas produced water management and beneficial use in the Western United States, US Department of the Interior, Bureau of Reclamation.

Haluszczak, L.O., Rose, A.W.,Kump, L.R., 2013. Geochemical evaluation of flowback brine from Marcellus gas wells in Pennsylvania, USA. Applied Geochemistry 28, 55-61.

Hamilton, J.D., 2008. Understanding crude oil prices. National Bureau of Economic Research (No. w14492).

Harkness, J.S., Dwyer, G.S., Warner, N.R., Parker, K.M., Mitch, W.A.,Vengosh, A., 2015. Iodide, bromide, and ammonium in hydraulic fracturing and oil and gas wastewaters: environmental implications. Environmental science \& technology 49(3), 1955-1963.

Hayes, T. 2009. Sampling and analysis of water streams associated with the development of Marcellus shale gas. Report by Gas Technology Institute, Des Plaines, IL, for the Marcellus Shale Coalition.

Higley, D.K.,Cox, D.O., 2007. Petroleum Systems and Assessment of Undiscovered Oil and Gas in the Denver Basin Province, Colorado, Kansas, Nebraska, South Dakota, and Wyoming-USGS Province.

Hill, R.T., FIMechE, B.C.,Director, A.D. 1993. Pipeline risk analysis, pp. 657-657, Hemsphere Publishing Corporation.

Hoelzer, K., Sumner, A.J., Karatum, O., Nelson, R.K., Drollette, B.D., O’Connor, M.P., D’Ambro, E.L., Getzinger, G.J., Ferguson, P.L.,Reddy, C.M., 2016. Indications of Transformation Products from Hydraulic Fracturing Additives in Shale-Gas Wastewater. Environmental science \& technology 50(15), 8036-8048.

Holloway, M.D.,Rudd, O.,2013. Fracking: The Operations and Environmental Consequences of Hydraulic Fracturing, John Wiley \& Sons.

Horn, S. 2013. Over 865,200 Gallons of Fracked Oil Spill in ND, Public In Dark For Days Due to Government Shutdown. http://www.desmogblog.com/2013/10/10/20600-barrelsfracked-oil-spill-north-dakota-publicity-halted-due-government-shutdown. (accessed July, 2015).

Horner, R., Harto, C.B., Jackson, R.B., Lowry, E.R., Brandt, A.R., Yeskoo, T., Murphy, D.J.,Clark, C.E., 2016. Water Use and Management in the Bakken Shale Oil Play in North Dakota. Environmental science \& technology 50(6), 3275-3282.

Igunnu, E.T.,Chen, G.Z., 2012. Produced water treatment technologies. International Journal of Low-Carbon Technologies, cts049.

IHS. 2016. US Well Data. https://www.ihs.com/products/us-well-data.html. (accessed August, 2016).

Jacobson, R. 2015. Fracking brine leak in North Dakota reaches Missouri River, prompts state Democrats to call for more regulation. http://www.pbs.org/newshour/rundown/frackingbrine-leak-north-dakota-reaches-missouri-river-prompts-state-democrats-call-regulation/. (accessed November, 2015).

Jiang, M., Hendrickson, C.T.,VanBriesen, J.M., 2014. Life cycle water consumption and wastewater generation impacts of a Marcellus shale gas well. Environmental science \& technology 48(3), 1911-1920.

Kaden, D.A.,Rose, T.L.,2015. Environmental and Health Issues in Unconventional Oil and Gas Development, Elsevier. 
Kahrilas, G.A., Blotevogel, J., Stewart, P.S.,Borch, T., 2014. Biocides in hydraulic fracturing fluids: A critical review of their usage, mobility, degradation, and toxicity. Environmental science \& technology 49(1), 16-32.

Kassotis, C.D., Tillitt, D.E., Lin, C.-H., McElroy, J.A.,Nagel, S.C., 2015. Endocrine-Disrupting Chemicals and Oil and Natural Gas Operations: Potential Environmental Contamination and Recommendations to Assess Complex Environmental Mixtures. Environ Health Perspect 124(3), 256-264.

Kemp, J. 2013. COLUMN-Toxic gas in Bakken pipeline points to sour well problem: Kemp. http://www.reuters.com/article/2013/05/29/column-kemp-bakken-pipelinesidUSL5N0EA3SU20130529\#id1OoUYCSjeuPkfC.97. (accessed December).

Kingston, P.F., 2002. Long-term environmental impact of oil spills. Spill Science \& Technology Bulletin 7(1), 53-61.

Kondash, A.,Vengosh, A., 2015. Water footprint of hydraulic fracturing. Environmental Science \& Technology Letters 2(10), 276-280.

Kurz, B.A., Stepan, D.J., Harju, J.A., Stevens, B.G.,Cowan, R.M., 2011. Bakken Water Opportunities Assessment - Phase 2 Evaluation Of Brackish Groundwater Treatment For Use In Hydraulic Fracturing Of The Bakken Play, North Dakota. Energy \& Environment Research Center, University of North Dakota.

Lampert, D.J., 2015. Comment on "Comparison of Water Use for Hydraulic Fracturing for Unconventional Oil and Gas versus Conventional Oil”. Environmental science \& technology 49(10), 6358-6359.

Lauer, N.E., Harkness, J.S.,Vengosh, A., 2016. Brine Spills Associated with Unconventional Oil Development in North Dakota. Environmental science \& technology 50(10), 5389-5397.

Lenntech. 2015. Elements. http://www.lenntech.com/periodic/elements/. (accessed November, 2015).

Lester, Y., Ferrer, I., Thurman, E.M., Sitterley, K.A., Korak, J.A., Aiken, G.,Linden, K.G., 2015. Characterization of hydraulic fracturing flowback water in Colorado: Implications for water treatment. Science of the Total Environment 512, 637-644.

Lord, D., Luketa, A., Wocken, C., Schlasner, S., Aulich, T., Allen, R.,Rudeen, D.K. 2015. Literature Survey of Crude Oil Properties Relevant to Handling and Fire Safety in Transport, Sandia National Laboratories (SNL-NM), Albuquerque, NM (United States).

Lyons, B. 2014. Produced Water: Asset or Waste? http://www.atlanticcouncil.org/images/publications/Produced_Water_Asset_or_Waste.pd f. (accessed December, 2015).

Maguire-Boyle, S.J.,Barron, A.R., 2014. Organic compounds in produced waters from shale gas wells. Environmental Science: Processes \& Impacts 16(10), 2237-2248.

McFeeley, M., 2012. State hydraulic fracturing disclosure rules and enforcement: a comparison. NRDC Issue brief ib:12-06-A.

McKenzie, L.M., Witter, R.Z., Newman, L.S.,Adgate, J.L., 2012. Human health risk assessment of air emissions from development of unconventional natural gas resources. Science of the Total Environment 424, 79-87.

McLaughlin, M.C., Borch, T.,Blotevogel, J., 2016. Spills of Hydraulic Fracturing Chemicals on Agricultural Topsoil: Biodegradation, Sorption, and Co-Contaminant Interactions. Environmental science \& technology 50(11), 6071-6078. 
1261

1262

1263

1264

1265

1266

1267

1268

1269

1270

1271

1272

1273

1274

1275

1276

1277

1278

1279

1280

1281

1282

1283

1284

1285

1286

1287

1288

1289

1290

1291

1292

1293

1294

1295

1296

1297

1298

1299

1300

1301

1302

1303

1304

1305

McMahon, P.B., Caldwell, R.R., Galloway, J.M., Valder, J.F.,Hunt, A.G., 2015. Quality and age of shallow groundwater in the Bakken Formation production area, Williston Basin, Montana and North Dakota. Groundwater 53(S1), 81-94.

Michie, T.W.,Koch, C.A., 1991. Evaluation of injection-well risk management in the Williston Basin. Journal of Petroleum Technology 43(06), 737-741.

Mitchell, J.H.,Child, N.J. 2015. Bakken Crude Oil Spills - Response Options And Environmental Impacts. http://www.mass.gov/eea/docs/dep/cleanup/laws/bakken-crudeoil-spills-response-options-and-environmental-impacts.pdf. (accessed December, 2015).

Moran, M.D., Cox, A.B., Wells, R.L., Benichou, C.C.,McClung, M.R., 2015. Habitat Loss and Modification Due to Gas Development in the Fayetteville Shale. Environmental management 55(6), 1276-1284.

Mordick, B. 2014. Widespread Contamination of Drinking Water from the East Poplar Oil Field in Montana. http://switchboard.nrdc.org/blogs/bmordick/widespread_contamination_of_dr.html. (accessed November, 2015).

Murex Petroleum Corporation. 2014. Hydraulic fracturing in the Bakken Petroleum System. https://mtech.edu/academics/mines/petroleum/spe/symposium/archives/2014/evolutionhydraulic-fracturing-bakken.pdf. (accessed August, 2016).

Natural gas extraction portal. 2015. Wastewater Discharges. http://www.envcap.org/energy/wastewater_discharges.cfm\#potw. (accessed December, 2015).

Nelson, A.W., Eitrheim, E.S., Knight, A.W., May, D., Mehrhoff, M.A., Shannon, R., Litman, R., Burnett, W.C., Forbes, T.Z.,Schultz, M.K., 2015. Understanding the Radioactive Ingrowth and Decay of Naturally Occurring Radioactive Materials in the Environment: An Analysis of Produced Fluids from the Marcellus Shale. Environ Health Perspect 123(7), 689.

New York State Department of Health. 2014. Transporting Crude Oil in New York State: A Review of Incident Prevention and Response Capacity. https://www.eli.org/sites/default/files/docs/nyscrudeoilreport.pdf. (accessed November, 2015).

NIH. 2014. Hydraulic Fracturing and Health. https://www.niehs.nih.gov/health/materials/hydraulic_fracturing and_health_508.pdf. (accessed August, 2016).

North Dakota Department of Health. 2014a. General Environmental Incident Summary. http://www.ndhealth.gov/EHS/FOIA/Spills/Summary_Reports/EIR3228_Summary_Repo rt.pdf. (accessed December, 2015).

North Dakota Department of Health. 2015a. Diesel Fuel Spill Reported in McKenzie County. http://www.ndhan.gov/data/mrNews/2015-0218\%20Diesel\%20Spill\%20in\%20McKenzie\%20FINAL.pdf. (accessed December, 2015).

North Dakota Department of Health. 2015b. Underground Injection Control Program. https://www.ndhealth.gov/WQ/GW/uic.htm. (accessed November, 2015).

North Dakota Department of Health. 2015c. Environmental Incident Reports. http://www.ndhealth.gov/EHS/Spills/. (accessed December, 2015).

North Dakota Department of Health. 2014b. General Environmental Incidents - Newer The New York Times http://www.ndhealth.gov/ehs/foia/spills/. (accessed December). 
1306

1307

1308

1309

1310

1311

1312

1313

1314

1315

1316

1317

1318

1319

1320

1321

1322

1323

1324

1325

1326

1327

1328

1329

1330

1331

1332

1333

1334

1335

1336

1337

1338

1339

1340

1341

1342

1343

1344

1345

1346

1347

1348

1349

1350

1351

North Dakota Department of Mineral Resources. 2014. Basic Services: Retrieve Well Scout Ticket Data Tool. https://www.dmr.nd.gov/oilgas/basicservice.asp. (accessed June, 2016).

North Dakota Department of Mineral Resources. 2015. ND Monthly Bakken Oil Production Statistics. https://www.dmr.nd.gov/oilgas/stats/historicalbakkenoilstats.pdf. (accessed November, 2015).

North Dakota Industrial Commission. 2014. NDIC adopts an additional flaring reduction policy. http://www.nd.gov/ndic/ic-press/DMR-Flaring140701.pdf. (accessed November, 2014).

North Dakota Industrial Commission Oil and Gas Division. 2015. North Dakota Century Code. https://www.dmr.nd.gov/oilgas/rules/rulebook.pdf. (accessed December, 2015).

North Dakota State Water Commission. 2014. Facts about North Dakota fracking and water use. http://www.swc.nd.gov/pdfs/fracking_water_use.pdf. (accessed July, 2015).

North Dakota State Water Commission. 2015a. 2015 North Dakota State Water Management Plan. http://www.swc.nd.gov/pdfs/water_plan.pdf. (accessed November, 2015).

North Dakota State Water Commission. 2015b. Today's Missouri River A North Dakota Perspective. http://www.swc.nd.gov/pdfs/missouri_river_today.pdf. (accessed November, 2015).

Orem, W., Tatu, C., Varonka, M., Lerch, H., Bates, A., Engle, M., Crosby, L.,McIntosh, J., 2014. Organic substances in produced and formation water from unconventional natural gas extraction in coal and shale. International Journal of Coal Geology 126, 20-31.

Parker, K.M., Zeng, T., Harkness, J., Vengosh, A.,Mitch, W.A., 2014. Enhanced formation of disinfection byproducts in shale gas wastewater-impacted drinking water supplies. Environmental science \& technology 48(19), 11161-11169.

Pearson, C.M., Griffin, L., Wright, C.A.,Weijers, L. 2013. Breaking up is hard to do: Creating hydraulic fracture complexity in the Bakken central basin, Society of Petroleum Engineers.

Pichtel, J., 2016. Oil and Gas Production Wastewater: Soil Contamination and Pollution Prevention. Applied and Environmental Soil Science 2016.

Plummer, M., Wood, T., Huang, H., Guo, L., Reiten, J., Chandler, K.,Metesh, J. 2015. Water Needs and Availability for Hydraulic Fracturing in the Bakken Formation, Eastern Montana. http://www2.epa.gov/sites/production/files/documents/plummer.pdf. (accessed November, 2015).

Preston, T.M., Chesley-Preston, T.L.,Thamke, J.N., 2014. A GIS-based vulnerability assessment of brine contamination to aquatic resources from oil and gas development in eastern Sheridan County, Montana. Science of the Total Environment 472, 1152-1162.

Propublica. 2012. North Dakota's Oil Boom Brings Damage Along With Prosperity. https://www.propublica.org/article/the-other-fracking-north-dakotas-oil-boom-bringsdamage-along-with-prosperi. (accessed July, 2016).

Purvis D. 2015. How Current Completion and Stimulation Practices Have Energized the Williston Basin. http://images.sdsmt.edu/learn/presentations/Purvis.pdf. (accessed August, 2016).

Rahm, D., Fields, B.,Farmer, J.L., 2015. Transportation Impacts of Fracking in the Eagle Ford Shale Development in Rural South Texas: Perceptions of Local Government Officials. Journal of Rural \& Community Development 10(2).

Rebhun, M., 2004. Desalination of reclaimed wastewater to prevent salinization of soils and groundwater. Desalination 160(2), 143-149. 
1352

1353

1354

1355

1356

1357

1358

1359

1360

1361

1362

1363

1364

1365

1366

1367

1368

1369

1370

1371

1372

1373

1374

1375

1376

1377

1378

1379

1380

1381

1382

1383

1384

1385

1386

1387

1388

1389

1390

1391

1392

1393

1394

1395

1396

Ridlington, E.,Rumpler, J., 2013. Fracking by the Numbers: Key Impacts of Dirty Drilling at the State and National Level. Environment America Research \& Policy Center, 46.

Rogers, J.D., Burke, T.L., Osborn, S.G.,Ryan, J.N., 2015. A framework for identifying organic compounds of concern in hydraulic fracturing fluids based on their mobility and persistence in groundwater. Environmental Science \& Technology Letters 2(6), 158-164. Roscoe Moss Company, 1990. Handbook of ground water development, John Wiley \& Sons.

Rozell, D.J.,Reaven, S.J., 2012. Water pollution risk associated with natural gas extraction from the Marcellus Shale. Risk Analysis 32(8), 1382-1393.

Scanlon, B.R., Reedy, R.C.,Nicot, J.-P., 2014. Comparison of water use for hydraulic fracturing for unconventional oil and gas versus conventional oil. Environmental science \& technology 48(20), 12386-12393.

Scanlon, B.R., Reedy, R.C.,Nicot, J.-P., 2015. Response to Comment on "Comparison of Water Use for Hydraulic Fracturing for Unconventional Oil and Gas versus Conventional Oil”. Environmental science \& technology 49(10), 6360-6361.

Shaffer, M. 2001. Waste lands: the threat of toxic fertilizer. California Public Interest Research Group Charitable Trust http://www.pirg.org/toxics/reports/wastelands/. (accessed December, 2015).

Shea, D., Hartman, K.,Qiu, S. 2015. Transporting crude oil by rail: State and federal action. http://www.ncsl.org/research/energy/transporting-crude-oil-by-rail-state-and-federalaction.aspx. (accessed November).

Skytruth. 2016. Fracking Chemical Database. http://frack.skytruth.org/fracking-chemicaldatabase. (accessed July, 2016).

Smith, B., 2009. Brine Contamination To Prairie Potholes From Energy Development In The Williston Basin: A Developing Integrated Science Project. 2009 Portland GSA Annual Meeting.

Stamford, L.,Azapagic, A., 2014. Life cycle environmental impacts of UK shale gas. Applied Energy 134, 506-518.

Stepan, D., Shockey, R., Kurz, B., Kalenze, N., Cowan, R., Ziman, J.,Harju, J. 2010. Bakken Water Opportunities Assessment: Phase 1. http://www.undeerc.org/Water/pdf/FracWaterPhaseIreport.pdf. (accessed December).

Stringfellow, W.T., Domen, J.K., Camarillo, M.K., Sandelin, W.L.,Borglin, S., 2014. Physical, chemical, and biological characteristics of compounds used in hydraulic fracturing. Journal of hazardous materials 275, 37-54.

Tchobanoglous, G.,Burton, F.L., 1991. Wastewater engineering. Management 7, 1-4.

Thamke, J.N.,Smith, B.D., 2014. Delineation of brine contamination in and near the East Poplar oil field, Fort Peck Indian Reservation, northeastern Montana, 2004-09. US Geological Survey Scientific Investigations Report 5024(40), 21.

The Guardian. 2015. North Dakota recorded 300 oil spills in two years without notifying the public. http://www.theguardian.com/environment/2013/oct/25/north-dakota-oil-pipelinespills-secrecy. (accessed July, 2015).

Torres, L., Yadav, O.P.,Khan, E., 2016. A review on risk assessment techniques for hydraulic fracturing water and produced water management implemented in onshore unconventional oil and gas production. Science of the Total Environment 539, 478-493.

U.S. Department of the Interior, U.S.G.S. 2015. Water Used for Hydraulic Fracturing Varies Widely Across United States. 

http://www.usgs.gov/newsroom/article.asp?ID=4262\#.VlSia3arRdg. (accessed November, 2015).

U.S. EIA. 2016. North Dakota Profile State Profile and Energy Estimates. http://www.eia.gov/state/?sid=ND. (accessed June, 2016).

U.S. EIA. 2015a. Natural Gas Gross Withdrawals and Production. http://www.eia.gov/dnav/ng/ng_prod_sum_dcu_spa_a.htm. (accessed December, 2015).

U.S. EIA. 2014 Texas State Profile and Energy Estimates. http://www.eia.gov/state/analysis.cfm?sid=TX. (accessed December, 2015).

U.S. EIA. 2014a. Bakken fuels North Dakota's oil production growth. http://www.eia.gov/todayinenergy/detail.cfm?id=17391. (accessed December, 2015).

U.S. EIA. 2013a. North Dakota oil production reaches new high in 2012, transported by trucks and railroads. http://www.eia.gov/todayinenergy/detail.cfm?id=10411. (accessed November, 2015).

U.S. EIA. 2013b. North Dakota sees increases in real GDP per capita following Bakken production. http://www.eia.gov/todayinenergy/detail.cfm?id=12071. . accessed December, 2015).

U.S. EIA. 2015b. Falling rig counts drive projected near-term oil production decline in 3 key U.S. regions. http://www.eia.gov/todayinenergy/detail.cfm?id=20392. (accessed December, 2015).

U.S. EIA. 2014b. North Dakota and Texas now provide nearly half of U.S. crude oil production. http://www.eia.gov/todayinenergy/detail.cfm?id=16931. (accessed December, 2015).

U.S. EIA. 2015c. Drilling Productivity Report. https://www.eia.gov/petroleum/drilling/pdf/dprfull.pdf. (accessed December, 2015).

U.S. EIA. 2014c. Crude-by-rail transportation provides Bakken Shale production access to major markets. http://www.eia.gov/todayinenergy/detail.cfm?id=16631. (accessed December, 2015).

U.S. EPA. 2015a. Analysis of Hydraulic Fracturing Fluid Data from the FracFocus Chemical Disclosure Registry 1.0. http://www.epa.gov/sites/production/files/201503/documents/fact_sheet analysis_of hydraulic_fracturing_fluid_data_from the_fracfoc u.pdf. (accessed December, 2015).

U.S. EPA. 2015b. Retrospective Case Study In Killdeer, North Dakota, Study Of The Potential Impacts Of Hydraulic Fracturing On Drinking Water Resources. https://www.epa.gov/hfstudy/retrospective-case-study-killdeer-north-dakota. (accessed June, 2016).

U.S. EPA. 2015c. Xylenes. http://www3.epa.gov/airtoxics/hlthef/xylenes.html. (accessed December, 2015).

U.S. EPA. 2016 Table of Regulated Drinking Water Contaminants. https://www.epa.gov/yourdrinking-water/table-regulated-drinking-water-contaminants. (accessed 2016).

U.S.Geological Survey. 2015. Williston and Powder River Basins Groundwater Availability Study. http://wy-mt.water.usgs.gov/projects/WaPR/index.html. (accessed December, 2015).

Uddameri, V., Morse, A.,Reible, D., 2014. Unconventional oil and natural gas resources development and their potential environmental impacts. Air and Waste Management Association, Pittsburgh, PA, 18-25. 
1441

1442

1443

1444

1445

1446

1447

1448

1449

1450

1451

1452

1453

1454

1455

1456

1457

1458

1459

1460

1461

1462

1463

1464

1465

1466

1467

1468

1469

1470

1471

1472

1473

1474

1475

1476
Upper Great Plains Transportation Institute. 2015. Nd Traffic Safety: Oil Counties Issue Brief:

Fall 2015. http://www.ugpti.org/rtssc/briefs/downloads/2015_TrafficSafety.pdf. (accessed June, 2016).

US EIA. 2014. North Dakota State Energy Profile. http://www.eia.gov/state/print.cfm?sid=ND. (accessed November, 2015).

USDA. 1998. Salinization. http://www.nrcs.usda.gov/Internet/FSE_DOCUMENTS/nrcs142p2_053151.pdf. (accessed December, 2015).

USGS. 2013. U.S. Geological Survey, recent and ongoing studies in the Williston Basin. November 2013. http://steppe.cr.usgs.gov/pdf/USGS_Multidisciplinary_Williston_Basin_Studies.pdf. (accessed December, 2015).

USGS. 2014a. STEPPE Overview:. http://steppe.cr.usgs.gov/overview.htm. (accessed December, 2015).

USGS. 2014b. Brine Contamination to Plains and Potholes Environments from Energy Development in the Williston Basin. http://steppe.cr.usgs.gov/overview.htm. (accessed December, 2015).

Vengosh, A., Jackson, R.B., Warner, N., Darrah, T.H.,Kondash, A., 2014. A critical review of the risks to water resources from unconventional shale gas development and hydraulic fracturing in the United States. Environmental science \& technology 48(15), 8334-8348.

Vidic, R.D., Brantley, S.L., Vandenbossche, J.M., Yoxtheimer, D.,Abad, J.D., 2013. Impact of shale gas development on regional water quality. Science 340(6134), 1235009.

Warner, N.R., Christie, C.A., Jackson, R.B.,Vengosh, A., 2013. Impacts of shale gas wastewater disposal on water quality in western Pennsylvania. Environmental science \& technology 47(20), 11849-11857.

WAWSA. 2016. Overview About WAWSA. http://wawsp.com/overview/. (accessed June, 2016).

WAWSA. 2015. THE buzz Your source for the latest information on the Western Area Water Supply Project, 4th Quarter 2015. http://wawsp.com/files/6714/4918/7504/TheBuzz4qtr2015.pdf. (accessed June, 2016).

Webb, E., Bushkin-Bedient, S., Cheng, A., Kassotis, C.D., Balise, V.,Nagel, S.C., 2014. Developmental and reproductive effects of chemicals associated with unconventional oil and natural gas operations. Reviews on environmental health 29(4), 307-318.

Wu, M.,Chiu, Y. 2011. Consumptive water use in the production of ethanonl and petroleum gasoline-2011 update, Argonne National Laboratory (ANL).

Zatta, P.,2003. Metal ions and neurodegenerative disorders, World Scientific. 
Table 1. Annual Total Water Consumption for Hydraulic Fracturing in the North Dakota Bakken Play (Adapted from Horner et. al., (2016))

\begin{tabular}{cccccc}
\hline & $\begin{array}{c}\text { Total water } \\
\text { consumed } \\
\text { (millions of } \\
\text { gallons) }\end{array}$ & $\begin{array}{c}\text { Total water } \\
\text { consumed } \\
\text { (millions of } \\
\text { litres) }\end{array}$ & $\begin{array}{c}\text { number of } \\
\text { wells }\end{array}$ & $\begin{array}{c}\text { average volume } \\
\text { per well } \\
\text { (millions of } \\
\text { gallons) }\end{array}$ & $\begin{array}{c}\text { volume } \\
\text { per well } \\
\text { (millions } \\
\text { of litres) }\end{array}$ \\
\hline 2008 & 770 & 2914.45 & 401 & NA & NA \\
2009 & 894 & 3383.79 & 465 & NA & NA \\
2010 & 1457 & 5514.745 & 758 & NA & NA \\
2011 & 2304 & 8720.64 & 1199 & 1.92 & 7.27 \\
2012 & 4274 & 16177.09 & 1801 & 2.37 & 8.97 \\
\hline
\end{tabular}


Table 2a. Comparison of the oil produced and water used in the individual stages of the COP and UOP

\begin{tabular}{|c|c|c|c|c|c|c|}
\hline \multicolumn{4}{|c|}{$\mathrm{COP}$} & \multicolumn{3}{|c|}{ UOP } \\
\hline & $\begin{array}{c}\text { Oil } \\
\text { production } \\
\text { (Million } \\
\text { litres/d) }\end{array}$ & $\begin{array}{l}\text { Water } \\
\text { used } \\
\text { (Million } \\
\text { litres/d) }\end{array}$ & $\begin{array}{l}\text { Litres of } \\
\text { water used } \\
\text { per litre of } \\
\text { oil produced }\end{array}$ & $\begin{array}{c}\text { Oil } \\
\text { production } \\
\text { (Million } \\
\text { litres/d) }\end{array}$ & $\begin{array}{l}\text { Water } \\
\text { used } \\
\text { (Million } \\
\text { litres/d) }\end{array}$ & $\begin{array}{c}\text { Litres of } \\
\text { water used } \\
\text { per litre of } \\
\text { oil produced }\end{array}$ \\
\hline Primary & 308.4 & 7.6 & 0.02 & 789.4 & 181.7 & 0.23 \\
\hline Secondary & 411.6 & 3531.4 & 8.6 & NA & NA & NA \\
\hline Tertiary & 103.2 & 893.3 & 8.7 & $\mathrm{U}$ & $\mathrm{U}$ & U \\
\hline
\end{tabular}

Table $2 \mathrm{~b}$. Ranking of COP and UOP based on oil produced and water used in different stages

\begin{tabular}{cccc}
\hline & \multicolumn{2}{c}{ Ranking } & \\
\hline & $\begin{array}{c}\text { On basis of Oil } \\
\text { produced }\end{array}$ & $\begin{array}{c}\text { On basis of } \\
\text { water used }\end{array}$ & $\begin{array}{c}\text { On basis of litres of } \\
\text { water used per litre } \\
\text { of oil produced }\end{array}$ \\
\hline Primary COP & 3 & 4 & 4 \\
Secondary COP & 2 & 1 & 2 \\
Tertiary COP & 4 & 2 & 1 \\
Primary UOP & 1 & 3 & 3 \\
EOR UOP & $\mathrm{U}$ & $\mathrm{U}$ & $\mathrm{U}$ \\
\hline
\end{tabular}

Note1: Table 5a is based on data from Wu and Chiu (2011), Kondash and Vengosh (2015).

Note2: Table 5b: Ranking 1-highest contribution; Ranking 4-least contribution

Note3: NA: Not applicable; U: Data is unavailable; COP-Conventional oil production; UOP- Unconventional oil production; EOR-Enhanced oil recovery

Note4: COP involves primary, secondary and tertiary stages (See Fig. 4)

Note5: UOP involves primary and enhanced recovery stages only (See Fig. 4) 
Table 3. Major Chemistry, Isotopic Ratios and Trace Metals of Produced water (Adapted from Lauer et al., (2016)) and Flowback water in Bakken (Adapted from Stepan et al., (2010) and Strong et al. (2013))

Note: PWn refers to produced water sample collected at site n (e.g., PW1 refers to the first sample), Specific locations for $\mathrm{PW}_{1}-\mathrm{PW}_{4}$ were not provided in the original source; FWn refers to Flowback water samples collected from the location n, Specific location detail for FW1 sample is shown is Figure S1; FW2 and FW3 samples were obtained in July 2012 from wells producing oil, Specific location details was not provided in original source

\begin{tabular}{|c|c|c|c|c|c|c|c|}
\hline \multirow{3}{*}{$\begin{array}{c}\text { Constitu } \\
\text { ent }\end{array}$} & \multicolumn{7}{|c|}{ Concentration $(\mathrm{mg} / \mathrm{L})$ found in Bakken produced water at different location } \\
\hline & \multicolumn{4}{|c|}{ Produced water } & \multicolumn{3}{|c|}{ Flowback water } \\
\hline & PW1 & PW2 & PW3 & PW4 & FW1 & FW2 & FW3 \\
\hline $\mathrm{Cl}$ & 119,989 & 75,892 & $21,728.0$ & 136,220 & $118,666.7$ & 125,818 & 903 \\
\hline $\mathrm{Br}$ & 558 & 384 & 91.6 & 601 & - & 576.8 & 37.5 \\
\hline $\mathrm{SO} 4$ & 128 & 102 & - & 293 & 650 & 532.9 & 360.4 \\
\hline $\mathrm{HCO} 3$ & 35 & 169 & 856 & - & 290.7 & - & - \\
\hline $\mathrm{Ca}$ & 12,033 & 8,573 & 372 & 15,346 & $9,683.3$ & 15,543 & 9,208 \\
\hline $\mathrm{Mg}$ & 1,001 & 741 & 118 & 1,299 & $1,273.3$ & - & - \\
\hline $\mathrm{Sr}$ & 774 & 551 & 33.1 & 970 & 764 & 915.8 & 57.2 \\
\hline $\mathrm{Na}$ & 47,217 & 34,745 & 12,271 & 60,571 & $61,466.7$ & - & - \\
\hline NH4 & 2,110 & 1,200 & 44.8 & 2,520 & - & - & - \\
\hline${ }^{87} \mathrm{Sr} /{ }^{86} \mathrm{Sr}$ & 0.7 & 0.7 & 0.7 & 0.7 & - & - & - \\
\hline $\mathrm{Li}$ & 31.5 & 19.7 & 2.9 & 37 & - & 34.7 & 0.7 \\
\hline B & 225.3 & 142.8 & 25.0 & 260.1 & - & - & - \\
\hline $\mathrm{Al}$ & 0.2 & 0.9 & 0.3 & 1.1 & $<1$ & - & - \\
\hline V & 1.0 & 0.6 & 0.1 & 1.0 & - & - & - \\
\hline $\mathrm{Mn}$ & 16.7 & 13.1 & 0.2 & 15.8 & 7.1 & - & - \\
\hline Co & 0.1 & 0.2 & 0.003 & 0.2 & - & - & - \\
\hline $\mathrm{Ni}$ & 0.5 & 0.6 & 0.009 & 0.8 & - & - & - \\
\hline $\mathrm{Cu}$ & 0.1 & 0.015 & 0.013 & 0.4 & 0.2 & - & - \\
\hline $\mathrm{Zn}$ & 12.5 & 3.8 & 0.0 & 17.1 & 6.7 & - & - \\
\hline $\mathrm{Se}$ & 0.9 & 0.6 & 0.1 & 1.0 & - & - & - \\
\hline
\end{tabular}




\begin{tabular}{ccccc|ccc}
$\mathrm{Rb}$ & 11.7 & 7.4 & 0.3 & 12.9 & - & - & - \\
$\mathrm{Tl}$ & 0.2 & 0.1 & 0.0 & 0.2 & & - & \\
$\mathrm{Fe}$ & 19.2 & 30.2 & 0.7 & 22.3 & 96 & - & - \\
$\mathrm{Ba}$ & 9.2 & 12.4 & 26.3 & 6.4 & 10.5 & 9.6 & 1.3 \\
$\mathrm{~Pb}$ & 0.6 & 0.1 & 0.0 & 3.5 & - & - & - \\
$\mathrm{Cd}$ & 0.021 & 0.022 & 0.001 & 0.031 & - & - & - \\
\hline
\end{tabular}


Table 4. Major Chemistry, and Trace Metals in the ground water at the median distance of 4.6 $\mathrm{km}$ from the nearest oil and gas well in the upper Fort Union Formation of the Bakken (Adapted from McMahon et al., (2015), Tchobanoglous and Burton, (1991))

\begin{tabular}{|c|c|c|}
\hline $\begin{array}{c}\text { Potential } \\
\text { Contaminant }\end{array}$ & $\begin{array}{c}\text { Concentration } \\
\text { in nearby } \\
\text { ground water } \\
\text { sources (Upper } \\
\text { Fort Union } \\
\text { Formation) } \\
(\mu \mathrm{g} / \mathrm{l})\end{array}$ & Potential Health hazard \\
\hline TDS & $3,590 * 10^{3}$ & Hardness, Deposits, Colored water, Staining ,Salty taste but no health hazard \\
\hline $\begin{array}{l}\text { Conductivity } \\
(\mathrm{mS} / \mathrm{cm})\end{array}$ & & Especially for fish and other aquatic species \\
\hline COD & & Especially for fish and other aquatic species \\
\hline $\mathrm{pH}$ & & Especially for fish and other aquatic species \\
\hline $\mathrm{Na}$ & & Kidney damage, Increases in blood pressure, Skin, Eyes, Nose and Throat irritation \\
\hline $\mathrm{Ca}$ & & Kidney stones, Reproductive toxicity \\
\hline K & & Fluid in the lungs, Eyes irritation, Nose and Throat Irritation \\
\hline $\mathrm{Mg}$ & & $\begin{array}{l}\text { Fever, Chills, Nausea, Vomiting \& muscle pain, Irritation of upper respiratory tract } \\
\text { irritation upon inhalation }\end{array}$ \\
\hline $\mathrm{Fe}$ & 4,460 & Conjunctivitis, Choroiditis, and Retinitis, Neurological disorder \\
\hline $\mathrm{P}$ & & Kidney damage, Osteoporosis ,Nausea, Stomach cramps and Drowsiness \\
\hline $\mathrm{NO}_{3}^{-}-\mathrm{N}$ & 6.47 & Harmful to infants, Shortness of breath and blue-baby syndrome \\
\hline $\mathrm{NO}_{2}^{-}-\mathrm{N}$ & & Harmful to infants, Shortness of breath and blue-baby syndrome \\
\hline $\mathrm{Si}$ & & Fibrosis in lung tissue, Skin and eyes irritation, Renal system diseases \\
\hline $\mathrm{Mn}$ & 1090 & $\begin{array}{l}\text { Hallucinations, Forgetfulness, Parkinson, Lung embolism, Bronchitis, Nerve damage, } \\
\text { Endocrine disruptor. }\end{array}$ \\
\hline $\mathrm{Al}$ & & $\begin{array}{l}\text { Severe trembling, Listlessness, Loss of memory, Damage to the central nervous system, } \\
\text { Dementia }\end{array}$ \\
\hline B & & Infection in stomach, liver, kidneys and brain \\
\hline $\mathrm{Ba}$ & 223 & $\begin{array}{l}\text { Flammable at room temperature in powder form, Long term- Increased blood pressure and } \\
\text { nerve block }\end{array}$ \\
\hline $\mathrm{Cd}$ & & $\begin{array}{l}\text { Flammable in powder form, Toxic by inhalation of dust or fume, A carcinogen. Soluble } \\
\text { compounds of Cd are highly toxic. Long term- concentrates in the liver, kidney, pancreas, } \\
\text { and thyroid, Hypertension suspected effect }\end{array}$ \\
\hline $\mathrm{Cu}$ & & Gastrointestinal distress, Liver or kidney damage, Neurological disorder \\
\hline $\mathrm{Cr}$ & & $\begin{array}{l}\text { Hexavalent } \mathrm{Cr} \text { compounds are carcinogens and corrosive on tissue. Long term- skin } \\
\text { sensitization and kidney damage, Reproductive toxicity }\end{array}$ \\
\hline $\mathrm{Li}$ & & Corrosive to the eyes, skin and respiratory tract \\
\hline
\end{tabular}


Ethylbenzene

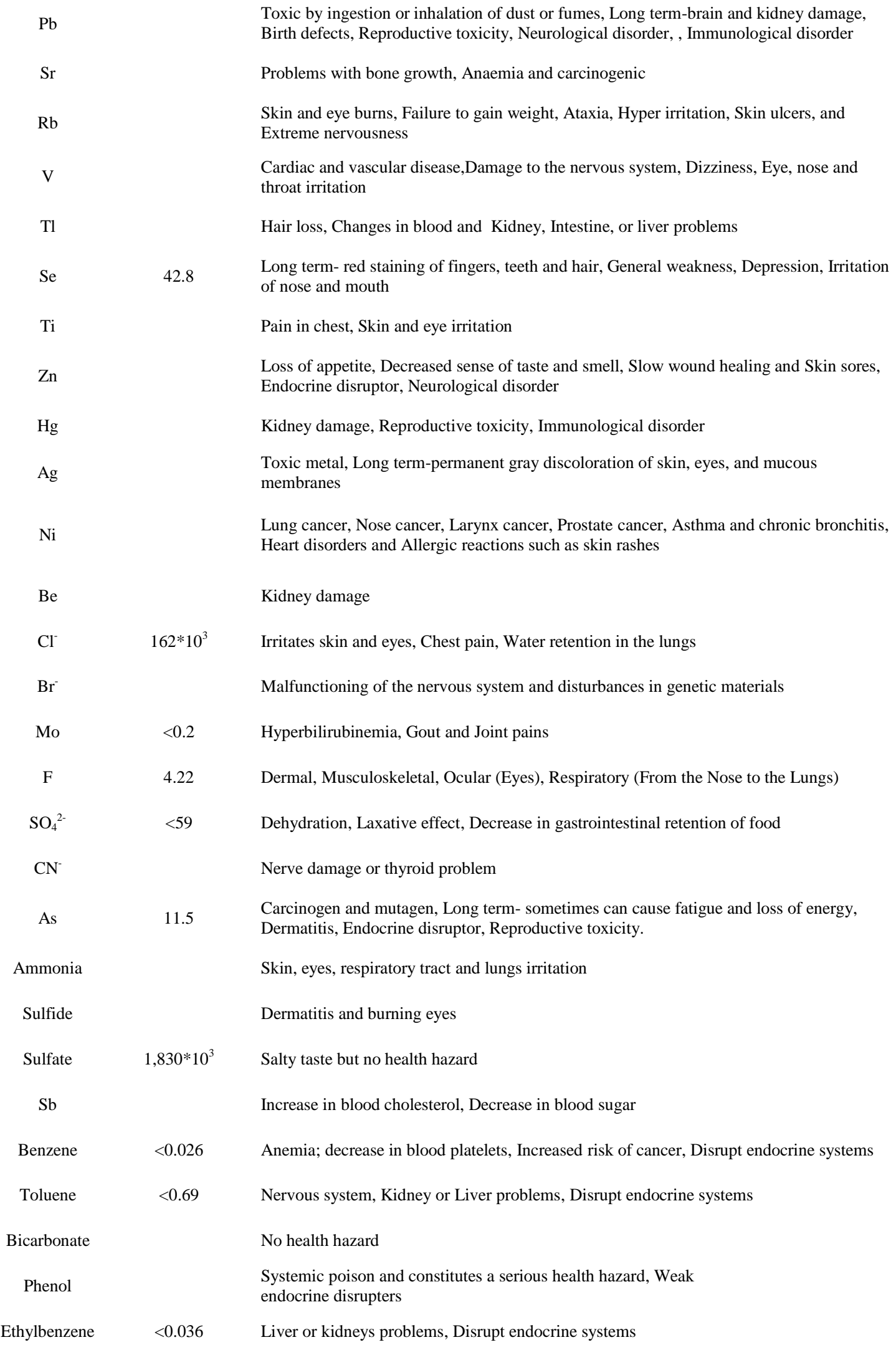

$\mathrm{Pb}$

$\mathrm{Sr}$

$\mathrm{Rb}$

V

Tl

Se

Ti

$\mathrm{Zn}$

$\mathrm{Hg}$

Ag

$\mathrm{Ni}$

Be

$\mathrm{Cl}^{-}$

$\mathrm{Br}^{-}$

Mo

F

$\mathrm{SO}_{4}{ }^{2-}$

$\mathrm{CN}^{-}$

As

Ammonia

Sulfide

Sulfate

$\mathrm{Sb}$

Benzene

Toluene

Bicarbonate

Phenol

Toxic by ingestion or inhalation of dust or fumes, Long term-brain and kidney damage, Birth defects, Reproductive toxicity, Neurological disorder, , Immunological disorder

Problems with bone growth, Anaemia and carcinogenic

Skin and eye burns, Failure to gain weight, Ataxia, Hyper irritation, Skin ulcers, and Extreme nervousness

Cardiac and vascular disease,Damage to the nervous system, Dizziness, Eye, nose and throat irritation

Hair loss, Changes in blood and Kidney, Intestine, or liver problems

Long term- red staining of fingers, teeth and hair, General weakness, Depression, Irritation of nose and mouth

Pain in chest, Skin and eye irritation

Loss of appetite, Decreased sense of taste and smell, Slow wound healing and Skin sores, Endocrine disruptor, Neurological disorder

Kidney damage, Reproductive toxicity, Immunological disorder

Toxic metal, Long term-permanent gray discoloration of skin, eyes, and mucous membranes

Lung cancer, Nose cancer, Larynx cancer, Prostate cancer, Asthma and chronic bronchitis, Heart disorders and Allergic reactions such as skin rashes

Kidney damage

$162 * 10^{3}$

Irritates skin and eyes, Chest pain, Water retention in the lungs

Malfunctioning of the nervous system and disturbances in genetic materials

Nerve damage or thyroid problem

Carcinogen and mutagen, Long term- sometimes can cause fatigue and loss of energy, Dermatitis, Endocrine disruptor, Reproductive toxicity.

Skin, eyes, respiratory tract and lungs irritation

Dermatitis and burning eyes

$1,830^{*} 10^{3}$

Salty taste but no health hazard

Increase in blood cholesterol, Decrease in blood sugar

$<0.026$

Anemia; decrease in blood platelets, Increased risk of cancer, Disrupt endocrine systems

Nervous system, Kidney or Liver problems, Disrupt endocrine systems

No health hazard

Systemic poison and constitutes a serious health hazard, Weak endocrine disrupters

$<0.036$

Liver or kidneys problems, Disrupt endocrine systems 
Xylenes

Cs

U

$\mathrm{Ra}$

Methane

Toxic on inhalation, Disrupt endocrine systems

Nausea, Vomiting, Diarrhea and Bleeding

23.2

Increased risk of cancer, Kidney toxicity

Increased risk of cancer 
Table 5. Comparison of State Hydraulic Fracturing Chemical Disclosure Regulations in Arkansas, Colorado, Louisiana, Montana, Wyoming, North Dakota and Pennsylvania (Adapted from Department of Natural Resources: State of Louisiana (2011))

\begin{tabular}{|c|c|c|c|c|c|c|c|}
\hline & Arkansas & Colorado & Louisiana & Montana & Wyoming & $\begin{array}{l}\text { North } \\
\text { Dakota }\end{array}$ & Pennsylvania \\
\hline Base Fluid Type & Yes & Yes & Yes & Yes & Yes & Yes & No \\
\hline $\begin{array}{l}\text { Base Fluid } \\
\text { Volume }\end{array}$ & Yes & Yes & Yes & Yes & Yes & Yes & Yes \\
\hline $\begin{array}{l}\text { Additive Trade } \\
\text { Name }\end{array}$ & Yes & Yes & Yes & $\begin{array}{l}\text { Yes (trade } \\
\text { secret only) }\end{array}$ & Yes & Yes & No \\
\hline Additive Vendor & Yes & Yes & Yes & Yes & No & Yes & No \\
\hline $\begin{array}{l}\text { Additive } \\
\text { Function }\end{array}$ & Yes & Yes & Yes & Yes & No & Yes & Yes \\
\hline $\begin{array}{l}\text { Additive } \\
\text { Concentration }\end{array}$ & Yes & Yes & Yes & Yes & Yes & Yes & Yes \\
\hline Chemical Names & $\begin{array}{l}\text { Yes } \\
\text { (Unless } \\
\text { trade } \\
\text { secret) }\end{array}$ & $\begin{array}{l}\text { Yes } \\
\text { (Unless } \\
\text { trade } \\
\text { secret) }\end{array}$ & $\begin{array}{l}\text { Yes (if subject } \\
\text { to } 29 \text { CFR } \\
1910.1200 \text { and } \\
\text { unless trade } \\
\text { secret) }\end{array}$ & $\begin{array}{l}\text { Yes (unless } \\
\text { trade secret) }\end{array}$ & Yes & Yes & $\begin{array}{l}\text { Yes (if subject } \\
\text { to } 29 \text { CFR } \\
1910.1200 \text { and } \\
\text { unless trade } \\
\text { secret) }\end{array}$ \\
\hline $\begin{array}{l}\text { Chemical } \\
\text { Concentration }\end{array}$ & No & $\begin{array}{l}\text { Yes } \\
\text { (Unless } \\
\text { trade } \\
\text { secret) }\end{array}$ & $\begin{array}{l}\text { Yes (if subject } \\
\text { to } 29 \text { CFR } \\
1910.1200 \text { and } \\
\text { unless trade } \\
\text { secret) }\end{array}$ & $\begin{array}{l}\text { Yes (unless } \\
\text { trade secret) }\end{array}$ & Yes & Yes & $\begin{array}{l}\text { Yes (if subject } \\
\text { to } 29 \text { CFR } \\
1910.1200 \text { and } \\
\text { unless trade } \\
\text { secret) }\end{array}$ \\
\hline $\begin{array}{l}\text { Chemical } \\
\text { Abstract Service } \\
\text { (CAS) Number }\end{array}$ & $\begin{array}{l}\text { Yes } \\
\text { (Unless } \\
\text { trade } \\
\text { secret) }\end{array}$ & $\begin{array}{l}\text { Yes } \\
\text { (Unless } \\
\text { trade } \\
\text { secret) }\end{array}$ & $\begin{array}{l}\text { Yes (if subject } \\
\text { to } 29 \text { CFR } \\
1910.1200 \text { and } \\
\text { unless trade } \\
\text { secret) }\end{array}$ & $\begin{array}{l}\text { Yes (trade } \\
\text { secret only) }\end{array}$ & No & Yes & $\begin{array}{l}\text { Yes (if subject } \\
\text { to } 29 \text { CFR } \\
1910.1200 \text { and } \\
\text { unless trade } \\
\text { secret) }\end{array}$ \\
\hline $\begin{array}{l}\text { Chemical Family } \\
\text { CAS Number }\end{array}$ & $\begin{array}{l}\text { Yes } \\
\text { (trade } \\
\text { secret } \\
\text { only) }\end{array}$ & $\begin{array}{l}\text { Yes } \\
\text { (Unless } \\
\text { trade } \\
\text { secret) }\end{array}$ & $\begin{array}{l}\text { Yes (trade } \\
\text { secret only) }\end{array}$ & $\begin{array}{l}\text { Yes (unless } \\
\text { trade secret) }\end{array}$ & No & No & No \\
\hline Effective Date & $\begin{array}{l}\text { January } \\
15,2011\end{array}$ & $\begin{array}{l}\text { April } \\
1,2012\end{array}$ & $\begin{array}{l}\text { October } \\
20,2011\end{array}$ & $\begin{array}{l}\text { August } \\
27,2011\end{array}$ & $\begin{array}{l}\text { October } \\
17,2010\end{array}$ & $\begin{array}{l}\text { September } \\
11,2011\end{array}$ & $\begin{array}{l}\text { February } \\
5,2011\end{array}$ \\
\hline
\end{tabular}


Table 6a. Representative, reported brine spills that occurred between 2015-2016 in North Dakota (Contained spills)

(Adapted from North Dakota Department of Health (2016))

\begin{tabular}{|c|c|c|c|c|c|c|}
\hline $\begin{array}{c}\text { Date } \\
\text { Incident }\end{array}$ & County & Well Name & $\begin{array}{c}\text { Spill } \\
\text { water } \\
\text { volume } \\
\text { (Barrels) }\end{array}$ & $\begin{array}{l}\text { Spill water } \\
\text { volume } \\
\text { (Litres) }\end{array}$ & $\begin{array}{c}\text { Other } \\
\text { Contaminant }\end{array}$ & Contained \\
\hline $6 / 19 / 2016$ & Burke & $\begin{array}{l}\text { CATHY EDWARDS } \\
\text { FEDERAL } 5992 \text { 31-2H }\end{array}$ & 150 & 23845.50 & $\begin{array}{l}\text { Produced } \\
\text { water }\end{array}$ & Yes \\
\hline $6 / 13 / 2016$ & Mountrail & $\begin{array}{l}\text { TIOGA-MADISON UNIT } \\
\text { N-140D }\end{array}$ & 770 & 122406.90 & & Yes \\
\hline $6 / 12 / 2016$ & Billings & BSMU 1701 CTB & 180 & 28614.60 & & Yes \\
\hline 6/9/2016 & Bottineau & ALICE-JEAN 33-30 & 190 & 30204.30 & & Yes \\
\hline $5 / 26 / 2016$ & Billings & $\begin{array}{l}\text { TR MADISON UNIT 21- } \\
14 \mathrm{H}\end{array}$ & 210 & 33383.70 & & Yes \\
\hline $5 / 24 / 2016$ & Mckenzie & $\begin{array}{l}\text { WEST CLARK SECTION } \\
1 \text { CENTRAL FACILITY }\end{array}$ & 150 & 23845.50 & & Yes \\
\hline $5 / 19 / 2016$ & Mckenzie & PM SWD 5198 13-18 & 115 & 18281.55 & & Yes \\
\hline $5 / 7 / 2016$ & Mountrail & $\begin{array}{l}\text { AUSTIN SECTION } 26 \\
\text { CENTRAL FACILITY }\end{array}$ & 259 & 41173.23 & & Yes \\
\hline $5 / 4 / 2016$ & Mckenzie & $\begin{array}{l}\text { GUNDER T. 151-101-30A- } \\
31-1 \mathrm{H}\end{array}$ & 80 & 12717.60 & & Yes \\
\hline $5 / 1 / 2016$ & Mckenzie & $\begin{array}{l}\text { GRIZZLY 146-99-3-3-10- } \\
14 \mathrm{H}\end{array}$ & 73 & 11604.81 & & Yes \\
\hline $4 / 29 / 2016$ & Mckenzie & Leiseth SWD \#1 & 240 & 38152.80 & & Yes \\
\hline $4 / 24 / 2016$ & Dunn & $\begin{array}{l}\text { MASTERS ENTERPRISES } \\
1\end{array}$ & 640 & 101740.80 & & Yes \\
\hline $4 / 21 / 2016$ & Billings & UVI FEDERAL 1-33 & 80 & 12717.60 & & Yes \\
\hline $3 / 29 / 2016$ & Billings & NERU 29-01 CTB & 320 & 50870.40 & $\begin{array}{l}\text { No other } \\
\text { substances } \\
\text { were } \\
\text { released. }\end{array}$ & Yes \\
\hline $3 / 13 / 2016$ & Bowman & ABRAHAMSON D-8 & 75 & 11922.75 & NA & Yes \\
\hline $3 / 11 / 2016$ & Mckenzie & MOEN 1-35 SWD & 190 & 30204.30 & & Yes \\
\hline $3 / 7 / 2016$ & Mckenzie & HYSTED 5200 11-30 CTB & 80 & 12717.60 & & Yes \\
\hline $3 / 1 / 2016$ & Mckenzie & GRIZZLY 1-25 SWD & 160 & 25435.20 & & Yes \\
\hline $2 / 25 / 2016$ & Mckenzie & $\begin{array}{l}\text { FORT BERTHOLD 152- } \\
\text { 93-19D-18-4H }\end{array}$ & 77 & 12240.69 & & Yes \\
\hline 2/3/2016 & Billings & $\begin{array}{l}\text { NORTH ELKHORN } \\
\text { RANCH UNIT } 2105\end{array}$ & 136 & 21619.92 & N/A & Yes \\
\hline 1/17/2016 & Mountrail & SAUBER $1-17 \mathrm{H}$ & 170 & 27024.90 & & Yes \\
\hline
\end{tabular}




\begin{tabular}{rrrrrlr} 
1/15/2016 & Williams & P HOVDE 8-20 SWD & 745 & 118432.65 & $\begin{array}{l}\text { Melted } \\
\text { snow } \\
\text { (freshwater) }\end{array}$ & Yes \\
12/28/2015 & Billings & BSMU 1701 CTB & 150 & 23845.50 & Yes \\
\hline
\end{tabular}

Table 6b. Representative, reported brine spills that occurred between 2015-2016 in North Dakota (Uncontained spills)

(Adapted from North Dakota Department of Health (2016))

\begin{tabular}{|c|c|c|c|c|c|c|}
\hline $\begin{array}{l}\text { Date } \\
\text { Incident }\end{array}$ & County & Well Name & $\begin{array}{c}\text { Spill } \\
\text { water } \\
\text { volume } \\
\text { (Barrels) }\end{array}$ & $\begin{array}{l}\text { Spill water } \\
\text { volume } \\
\text { (Litres) }\end{array}$ & $\begin{array}{c}\text { Other } \\
\text { Contaminant }\end{array}$ & Contained \\
\hline $6 / 14 / 2016$ & Renville & TRURO MADISON UNIT & 210 & 33383.70 & & No \\
\hline $6 / 8 / 2016$ & Dunn & $\begin{array}{l}\text { FORT BERTHOLD 148-94- } \\
\text { 33D-28-6H }\end{array}$ & 5 & 794.85 & $\begin{array}{l}\text { Brine due to } \\
\text { vandalism. }\end{array}$ & No \\
\hline $6 / 5 / 2016$ & Burke & SCHULTZ 1 SWDW & 5 & 794.85 & & No \\
\hline $5 / 9 / 2016$ & Bottineau & JOHNSON 24-19 & 5 & 794.85 & & No \\
\hline $5 / 1 / 2016$ & Dunn & LIKES EAGLE \#2-31H & 50 & 7948.50 & $\begin{array}{l}\text { An } \\
\text { estimated } 50 \\
\text { bbls of } \\
\text { produced } \\
\text { water was } \\
\text { illegally } \\
\text { dumped by } \\
\text { an unknown } \\
\text { party on } \\
\text { property } \\
\text { adjacent to } \\
\text { our well } \\
\text { pad. }\end{array}$ & No \\
\hline $4 / 28 / 2016$ & Burke & RMU BATTERY 4 & 40 & 6358.80 & & No \\
\hline $3 / 27 / 2016$ & Williams & P EVITT 12-12 SWD & 2 & 317.94 & & No \\
\hline $3 / 6 / 2016$ & Williams & $\begin{array}{l}\text { CHEETAH 10-10H \& LION 1- } \\
14 \mathrm{H}\end{array}$ & 2733 & 434465.01 & & No \\
\hline $2 / 22 / 2016$ & Dunn & RECKARD SWD \#1 & 149 & 23686.53 & & No \\
\hline $2 / 18 / 2016$ & $\begin{array}{l}\text { Golden } \\
\text { valley }\end{array}$ & & 20 & 3179.40 & & No \\
\hline $2 / 12 / 2016$ & Dunn & BOREJAKS SWD 2 & 78 & 12399.66 & NA & No \\
\hline $2 / 6 / 2016$ & Williams & Stokke SWD & 10 & 1589.70 & & No \\
\hline $1 / 23 / 2016$ & Bowman & BRADAC CTB & 4 & 635.88 & & No \\
\hline $1 / 11 / 2016$ & Renville & V. HARRIS-MONTANA 1 & 50 & 7948.50 & & No \\
\hline
\end{tabular}




\begin{tabular}{|c|c|c|c|c|c|c|}
\hline $1 / 7 / 2016$ & Williams & & 187 & 29727.39 & N/A & No \\
\hline $12 / 11 / 2015$ & Divide & & 0.24 & 37.85 & Salt Water & No \\
\hline $12 / 7 / 2015$ & Mckenzie & JONES USA CTB & 90 & 14307.30 & & No \\
\hline $12 / 6 / 2015$ & Divide & & 5 & 794.85 & & No \\
\hline $12 / 5 / 2015$ & Burke & CHREST 22-26 & 6 & 953.82 & & No \\
\hline $12 / 5 / 2015$ & Mountrail & BURKE 100-20H & 10 & 1589.70 & & No \\
\hline $11 / 23 / 2015$ & Mountrail & Evans SWD \#1 & 15 & 2384.55 & & No \\
\hline 10/10/2015 & Dunn & & 0.48 & 75.70 & Brine Water & No \\
\hline $10 / 3 / 2015$ & Dunn & ECKELBERG 14-23TFH & 60 & 9538.20 & & No \\
\hline $9 / 30 / 2015$ & Billings & $\begin{array}{l}\text { FRYBURG HEATH- } \\
\text { MADISON UNIT F-812 }\end{array}$ & 70 & 11127.90 & & No \\
\hline $8 / 5 / 2015$ & Divide & NOVA 4-9-163-98H & 4260 & 677212.20 & & No \\
\hline $7 / 24 / 2015$ & Bottineau & KING SWD SYSTEM D01 & 50 & 7948.50 & $\begin{array}{l}\text { Also } \\
\text { recovered } \\
100 \text { bbls of } \\
\text { standing } \\
\text { water from } \\
\text { ditch area. }\end{array}$ & No \\
\hline $7 / 20 / 2015$ & Williams & CHARLESTON 4-22H1 & 3 & 476.91 & & No \\
\hline
\end{tabular}


Table 7. U.S. Geological Survey, recent and ongoing studies in the Williston Basin. November 2013 (Adapted from USGS (2013))

\begin{tabular}{|c|c|c|}
\hline Year & Project Title & Relevant Publication/Reports \\
\hline 2003-present & $\begin{array}{l}\text { Delineation of brine contamination in and near the East } \\
\text { Poplar oil field, Fort Peck Indian Reservation, northeastern } \\
\text { Montana }\end{array}$ & $\begin{array}{l}\text { (Thamke and Smith, 2014) } \\
\text { http://pubs.usgs.gov/sir/2014/50 } \\
\text { 24/ }\end{array}$ \\
\hline 2008-present & $\begin{array}{l}\text { Brine Contamination to Prairie Potholes from Energy } \\
\text { Development in the Williston Basin }\end{array}$ & $\begin{array}{l}\text { (Smith, 2009) } \\
\text { https://gsa.confex.com/gsa/2009 } \\
\text { AM/finalprogram/abstract_1633 } \\
\text { 10.htm }\end{array}$ \\
\hline 2010-present & Water Balances for Energy Resource Production & $\begin{array}{l}\text { On-going study, publication in } \\
\text { preparation } \\
\text { http://energy.usgs.gov/HealthEn } \\
\text { vironment/EnergyProductionUs } \\
\text { e/ProducedWaters.aspx } \\
\text { (Prestonet al }\end{array}$ \\
\hline 2011-2012 & $\begin{array}{l}\text { A GIS-Based Vulnerability Assessment of Brine } \\
\text { Contamination to Aquatic Resources from Oil and Gas } \\
\text { Development in Eastern Sheridan County, MT }\end{array}$ & $\begin{array}{l}\text { (Preston et al., 2014) } \\
\text { http://www.sciencedirect.com/sc } \\
\text { ience/article/pii/S004896971301 } \\
0656\end{array}$ \\
\hline $2012-2015$ & Williston and Powder River basins groundwater availability & $\begin{array}{l}\text { South Dakota School of Mines } \\
\text { Theses 2013, USGS } \\
\text { publications in preparation } \\
\text { http://mt.water.usgs.gov/project } \\
\text { s/WaPR/ }\end{array}$ \\
\hline 2012-present & $\begin{array}{l}\text { Investigating the biological impacts of brine contamination } \\
\text { on wetlands of the Prairie Pothole Region: Developing maps } \\
\text { depicting conditions in the ecosystems }\end{array}$ & On-going study \\
\hline 2012-present & $\begin{array}{l}\text { Spatial characterization of wetland surface water } \\
\text { contamination risk from oil development in the Prairie } \\
\text { Pothole Region of North Dakota }\end{array}$ & $\begin{array}{l}\text { On-going study, publication in } \\
\text { preparation }\end{array}$ \\
\hline 2012-present & $\begin{array}{l}\text { Baseline Chemical and Isotopic Data for Produced Water } \\
\text { from the Bakken Formation, Williston Basin }\end{array}$ & $\begin{array}{l}\text { Data available in USGS } \\
\text { National Water Information } \\
\text { System at } \\
\text { http://mt.water.usgs.gov/ }\end{array}$ \\
\hline $2012-2015$ & Effects of oil and gas development on grassland birds & On-going study \\
\hline $2013-2014$ & $\begin{array}{l}\text { Presence and Abundance of Invasive Species and Non- } \\
\text { Native Perennial Grasses Related to Energy Development in } \\
\text { Montana and North Dakota }\end{array}$ & On-going study \\
\hline $2013-2014$ & $\begin{array}{l}\text { Comprehensive Wetland Assessment and Monitoring } \\
\text { Program within the Lost wood Complex of Northeast } \\
\text { Montana and Northwest North Dakota }\end{array}$ & $\begin{array}{l}\text { Final report to U.S. Fish \& } \\
\text { Wildlife Service in preparation }\end{array}$ \\
\hline 2013 & Williston Basin Baseline Water-Quality Assessment & On-going study \\
\hline $2013-2014$ & $\begin{array}{l}\text { Quantifying water-use requirements for the variable } \\
\text { conditions and processes associated with hydraulic fracturing } \\
\text { within North Dakota, South Dakota, and Montana }\end{array}$ & On-going study \\
\hline
\end{tabular}


Updating, gathering and serving datasets relevant to oil and

2014 gas development and fish and wildlife management within the Williston Basin and Bakken Formation

On-going study

Evaluating recent and future land-use changes related to

2014 energy development in the Williston Basin and Bakken

Formation

On-going study

A Web-Based Tool to Evaluate Potential Saline 
Table 8a. Major Chemistry, Isotopic Ratios and Trace Metals of the impacted surface water due to the Bear Den Bay Spill and Blacktail Creek Spills related to the unconventional oil production from the Bakken shale (Adapted from Lauer et al., (2016))

Note: Details on the geographical location of the spill site is provided in Figure S3.

\begin{tabular}{|c|c|c|c|c|c|c|}
\hline \multirow[b]{2}{*}{ Constituent } & \multicolumn{6}{|c|}{ Concentration $(\mathrm{mg} / \mathrm{L})$ found in different locations of Bear Den Bay Spill and Blacktail Creek Spill } \\
\hline & $\begin{array}{l}\text { Background } \\
\text { water }\end{array}$ & $\begin{array}{l}\text { Bear Den Bay Spill } \\
\text { site (ND102*) }\end{array}$ & $\begin{array}{l}\text { Bear Den Brine } \\
\text { Spill, (ND103*) } \\
\text { uphill of ND102 }\end{array}$ & $\begin{array}{c}\text { Brine Spill adjacent } \\
\text { to plant (ND113*) }\end{array}$ & $\begin{array}{l}\text { Blacktail Creek } \\
\text { (ND123*,10 m } \\
\text { downstream of } \\
\text { spill) }\end{array}$ & $\begin{array}{l}\text { Blacktail Creek } \\
\text { spill site (ND126*) }\end{array}$ \\
\hline $\mathrm{Cl}$ & 21 & $14,795.000$ & $16,032.000$ & 996.000 & $1,487.000$ & $1,900.000$ \\
\hline $\mathrm{Br}$ & 0.73 & 72.500 & 74.000 & 5.500 & 5.200 & 5.900 \\
\hline $\mathrm{SO} 4$ & 1658 & $1,713.000$ & $3,210.000$ & $4,090.000$ & $3,025.000$ & $3,117.000$ \\
\hline $\mathrm{HCO} 3$ & 687 & 279.000 & 247.000 & 668.000 & 880.000 & 941.000 \\
\hline $\mathrm{Ca}$ & 121 & $1,953.000$ & $1,773.000$ & 576.000 & 156.000 & 212.000 \\
\hline $\mathrm{Mg}$ & 104 & 684.000 & 902.000 & 376.000 & 235.000 & 258.000 \\
\hline $\mathrm{Sr}$ & 1.41 & 52.600 & 51.100 & 5.670 & 3.480 & 4.700 \\
\hline $\mathrm{Na}$ & 733 & $6,003.000$ & $6,754.000$ & $1,513.000$ & $2,029.000$ & $2,282.000$ \\
\hline NH4 & 0.93 & 9.140 & 42.400 & 0.620 & 21.000 & 17.000 \\
\hline${ }^{87} \mathrm{Sr} /{ }^{86} \mathrm{Sr}$ & 0.7082 & 0.710 & 0.710 & 0.708 & 0.710 & 0.710 \\
\hline $\mathrm{Li}$ & 0.103 & 3.244 & 3.490 & 0.478 & 0.476 & 0.542 \\
\hline B & 0.502 & 13.140 & 15.501 & 0.511 & 3.217 & 3.995 \\
\hline $\mathrm{Al}$ & 0.087 & 0.202 & 0.137 & 0.028 & 0.026 & 0.041 \\
\hline $\mathrm{V}$ & 0.0036 & 0.148 & 0.171 & 0.012 & 0.022 & 0.025 \\
\hline $\mathrm{Mn}$ & 0.304 & 3.418 & 0.839 & 1.924 & 0.598 & 0.811 \\
\hline Co & 0.0009 & 0.009 & 0.005 & 0.001 & 0.001 & 0.001 \\
\hline $\mathrm{Ni}$ & 0.0043 & 0.044 & 0.025 & 0.004 & 0.001 & - \\
\hline $\mathrm{Cu}$ & 0.0036 & 0.021 & 0.025 & 0.004 & 0.003 & 0.003 \\
\hline $\mathrm{Zn}$ & 0.0068 & 0.088 & 0.052 & 0.010 & 0.012 & 0.025 \\
\hline $\mathrm{Se}$ & 0.0011 & 0.095 & 0.132 & 0.008 & 0.007 & 0.007 \\
\hline
\end{tabular}




\begin{tabular}{cccccccc}
$\mathrm{Rb}$ & 0.0035 & 0.211 & 0.236 & 0.022 & 0.056 & 0.071 \\
$\mathrm{Tl}$ & 0 & 0.006 & 0.005 & - & 0.000 & 0.211 & 0.079 \\
$\mathrm{Fe}$ & 0.335 & 2.673 & 2.468 & 0.771 & 0.062 & 0.070 \\
$\mathrm{Ba}$ & 0.052 & 0.392 & 0.274 & 0.054 & 0.001 & 0.001 \\
$\mathrm{~Pb}$ & 0.0002 & 0.008 & 0.008 & 0.001 & - & 0.001 \\
$\mathrm{Cd}$ & 0.0001 & 0.003 & 0.003 & - & & \\
\hline
\end{tabular}

Note: Background water is the surface water

*Sample (Latitude, Longitude): ND102 (47.78302, -102.65152), ND103 (47.7827, -102.651147.7827), ND113 (47.86885, -102.95044), ND123 (48.39835, -103.62457), ND126 (48.39835, -103.62457),

Table 8b. Major Chemistry, Isotopic Ratios and Trace Metals of the impacted surface water due to the Bottineau County Spill related to the unconventional oil production from the Bakken shale (Adapted from Lauer et al., (2016))

\begin{tabular}{|c|c|c|c|c|c|c|}
\hline \multirow[b]{2}{*}{ Constituent } & \multicolumn{6}{|c|}{ Concentration $(\mathrm{mg} / \mathrm{L})$ found in different locations of Bottineau County Spill } \\
\hline & $\begin{array}{l}\text { Background } \\
\text { water }\end{array}$ & $\begin{array}{l}\text { Bottineau County } \\
\text { Spill (ND120*, } \\
\text { Located adjacent to } \\
\text { well pad ) }\end{array}$ & $\begin{array}{l}\text { Bottineau County } \\
\text { Spill site } \\
\text { (ND128*,0.1 mile } \\
\text { away from storage } \\
\text { tanks) }\end{array}$ & $\begin{array}{l}\text { Bottineau County } \\
\text { Spill site (ND129*, } 0.25 \\
\text { mile away from spill) }\end{array}$ & $\begin{array}{l}\text { Bottineau County } \\
\text { spill (ND130*, } \\
0.25 \text { mile away } \\
\text { from spill site) }\end{array}$ & $\begin{array}{c}\text { Bottineau } \\
\text { County spill site } \\
\text { (ND131*, } \\
\text { Located in ditch } \\
\text { on side of road } \\
\text { next to rig) }\end{array}$ \\
\hline $\mathrm{Cl}$ & 21 & 207.000 & 269.000 & $5,833.000$ & 189.000 & $18,703.000$ \\
\hline $\mathrm{Br}$ & 0.73 & 0.220 & 0.560 & 5.800 & 0.170 & 20.500 \\
\hline $\mathrm{SO} 4$ & 1658 & 464.000 & 946.000 & 856.000 & 387.000 & $2,739.000$ \\
\hline $\mathrm{HCO} 3$ & 687 & 306.000 & 466.000 & 116.000 & 345.000 & 110.000 \\
\hline $\mathrm{Ca}$ & 121 & 111.000 & 187.000 & $1,225.000$ & 109.000 & $1,381.000$ \\
\hline $\mathrm{Mg}$ & 104 & 101.000 & 148.000 & 475.000 & 91.000 & $2,220.000$ \\
\hline $\mathrm{Sr}$ & 1.41 & 0.460 & 0.890 & 5.940 & 0.490 & 8.530 \\
\hline $\mathrm{Na}$ & 733 & 102.000 & 298.000 & $1,876.000$ & 99.300 & $6,829.000$ \\
\hline NH4 & 0.93 & 0.760 & 0.400 & $<0.01$ & 0.190 & 0.320 \\
\hline${ }^{87} \mathrm{Sr} /{ }^{86} \mathrm{Sr}$ & 0.7082 & 0.710 & 0.710 & 0.709 & 0.710 & 0.710 \\
\hline
\end{tabular}




\begin{tabular}{|c|c|c|c|c|c|c|}
\hline $\mathrm{Li}$ & 0.103 & 0.067 & 0.213 & 0.804 & 0.079 & 1.196 \\
\hline B & 0.502 & 0.224 & 0.193 & 5.358 & 0.039 & 1.155 \\
\hline $\mathrm{Al}$ & 0.087 & 0.012 & 0.009 & 0.017 & 0.009 & 0.086 \\
\hline $\mathrm{V}$ & 0.0036 & 0.005 & 0.010 & 0.073 & 0.005 & 0.218 \\
\hline $\mathrm{Mn}$ & 0.304 & 0.107 & 1.555 & 1.984 & 0.306 & 0.725 \\
\hline Co & 0.0009 & 0.001 & 0.002 & 0.002 & 0.000 & 0.003 \\
\hline $\mathrm{Ni}$ & 0.0043 & 0.003 & 0.005 & 0.014 & 0.001 & 0.028 \\
\hline $\mathrm{Cu}$ & 0.0036 & 0.002 & 0.002 & 0.005 & 0.001 & 0.028 \\
\hline $\mathrm{Zn}$ & 0.0068 & 0.015 & 0.004 & 0.012 & 0.003 & 0.024 \\
\hline $\mathrm{Se}$ & 0.0011 & 0.001 & 0.001 & 0.049 & 0.001 & 0.172 \\
\hline $\mathrm{Rb}$ & 0.0035 & 0.004 & 0.008 & 0.044 & 0.003 & 0.005 \\
\hline $\mathrm{Tl}$ & 0 & - & - & 0.000 & - & 0.000 \\
\hline $\mathrm{Fe}$ & 0.335 & 0.161 & 0.271 & 1.517 & 0.148 & 1.901 \\
\hline $\mathrm{Ba}$ & 0.052 & 0.110 & 0.078 & 0.512 & 0.117 & 0.194 \\
\hline $\mathrm{Pb}$ & 0.0002 & 0.000 & 0.000 & 0.003 & - & 0.006 \\
\hline $\mathrm{Cd}$ & 0.0001 & - & 0.000 & - & - & 0.001 \\
\hline
\end{tabular}

Note: Background water is the surface water

*Sample (Latitude, Longitude): ND120 (48.47578, -102.8269), ND128 (48.77762, -101.31268), ND129 (48.79811, -101.34384), ND130 (48.80805, -101.19978), ND131 (48.73949, -101.23452) 
Table 9.Recommendation on Bakken crude oil production

\begin{tabular}{|c|c|c|c|c|c|}
\hline$\#$ & $\begin{array}{l}\text { Water cycle } \\
\text { stage }\end{array}$ & Problem statement & Environmental Concern & Possible solution & Reference \\
\hline \multirow[t]{5}{*}{1} & \multirow[t]{5}{*}{$\begin{array}{l}\text { Water } \\
\text { acquisition } \\
\text { (Stage I) }\end{array}$} & \multirow[t]{2}{*}{$\begin{array}{l}\text { Increasing freshwater water } \\
\text { demand and water stress }\end{array}$} & \multirow[t]{2}{*}{$\begin{array}{l}\text { Excessive withdrawals of } \\
\text { freshwater from arid regions } \\
\text { can stress the regional water } \\
\text { resources and affect existing } \\
\text { sectors including } \\
\text { agriculture, hydropower, } \\
\text { recreation }\end{array}$} & $\begin{array}{l}\text { Develop novel technologies for recycling and } \\
\text { reusing produced water. Such technologies } \\
\text { should be capable of separating high dissolved } \\
\text { solids from produced water typical to Bakken } \\
\text { Shale. Such innovative technologies include: } \\
\text { i) Microbial capacitive deionization (Forrestal } \\
\text { et al., 2016), ii) Microbial mats (Akyon et al., } \\
\text { 2015), and iii) Marginal waster (e.g., Acid- } \\
\text { mine drainage) for produced water treatment } \\
\text { (Vengosh et al., 2015). }\end{array}$ & $\begin{array}{l}\text { (Igunnu } \\
\text { and Chen, } \\
\text { 2012) }\end{array}$ \\
\hline & & & & Develop alternate water sources for fracturing & $\begin{array}{l}\text { (Vengosh } \\
\text { et al., } \\
2014 \text { ) }\end{array}$ \\
\hline & & $\begin{array}{l}\text { Large volumes of maintenance } \\
\text { water to avoid salinity buildup } \\
\text { in Bakken shale }\end{array}$ & $\begin{array}{l}\text { Excessive withdrawals of } \\
\text { freshwater }\end{array}$ & $\begin{array}{l}\text { Develop alternate water sources (brackish to } \\
\text { saline groundwater, treated } \\
\text { domestic wastewater) for fracturing }\end{array}$ & $\begin{array}{l}\text { (Vengosh } \\
\text { et al., } \\
2014)\end{array}$ \\
\hline & & $\begin{array}{l}\text { Existing groundwater } \\
\text { resources are inadequate to } \\
\text { meet the increasing freshwater } \\
\text { demand }\end{array}$ & $\begin{array}{l}\text { Inability to meet increased } \\
\text { water demands in Bakken } \\
\text { for direct (fracturing and } \\
\text { brine dilution) and indirect } \\
\text { uses (domestic water use by } \\
\text { the temporary oilfield } \\
\text { services population) }\end{array}$ & $\begin{array}{l}\text { Surface water resources (e.g., Missouri river) } \\
\text { may be used provided that access is available }\end{array}$ & $\begin{array}{l}\text { (Horner et } \\
\text { al. 2016) }\end{array}$ \\
\hline & & $\begin{array}{l}\text { Limited information on water } \\
\text { utilization data for hydraulic } \\
\text { fracturing (HF) in ND }\end{array}$ & $\begin{array}{l}\text { Extrapolated or conservative } \\
\text { conclusions related to water } \\
\text { stress issues }\end{array}$ & $\begin{array}{l}\text { More case studies are required to investigate } \\
\text { water usage on the spatial and temporal scale }\end{array}$ & $\begin{array}{l}\text { (Gordon } \\
\text { and } \\
\text { Garner, } \\
\text { 2014) }\end{array}$ \\
\hline
\end{tabular}




\begin{tabular}{|c|c|c|c|c|c|}
\hline & \multirow[t]{3}{*}{$\begin{array}{l}\text { Produced } \\
\text { and } \\
\text { Flowback } \\
\text { water } \\
\text { Production } \\
\text { (Stage IV) }\end{array}$} & $\begin{array}{l}\text { Limited data on } \\
\text { physiochemical properties, } \\
\text { toxicity of the chemicals used } \\
\text { in fracturing }\end{array}$ & $\begin{array}{l}\text { Inadequate data to carryout } \\
\text { health and environmental } \\
\text { impacts risk assessment due } \\
\text { to brine spills and } \\
\text { wastewater leaks into } \\
\text { drinking water resources }\end{array}$ & $\begin{array}{l}\text { Develop analytical methods to determine a } \\
\text { suite of organic, inorganic and other } \\
\text { chemicals. } \\
\text { More peer-reviewed studies to investigate } \\
\text { chemicals in produced and flowback water } \\
\text { from Bakken shale } \\
\text { Learn from the existing studies available from } \\
\text { contemporary shales }\end{array}$ & $\begin{array}{l}\text { (Stringfell } \\
\text { ow et al., } \\
2014)\end{array}$ \\
\hline & & $\begin{array}{l}\text { Energy-development activities } \\
\text { in Bakken can potentially } \\
\text { affect groundwater resources }\end{array}$ & $\begin{array}{l}\text { Inorganic chemical, organic } \\
\text { chemical, noble-gas and } \\
\text { brine can accumulate in the } \\
\text { groundwater and can remain } \\
\text { undetected for several years }\end{array}$ & $\begin{array}{l}\text { Long-term monitoring of groundwater using a } \\
\text { new geochemical and isotopic tracers that are } \\
\text { suitable for proving or refuting the evidence } \\
\text { for water contamination due to ND Bakken } \\
\text { shale development } \\
\text { Studies near the oil wells, rather than further } \\
\text { away from contaminated sites }\end{array}$ & $\begin{array}{l}\text { (McMaho } \\
\text { n et al., } \\
\text { 2015) }\end{array}$ \\
\hline & & $\begin{array}{l}\text { Contamination of agricultural } \\
\text { soil due to the migration and } \\
\text { spills related to flowback and } \\
\text { produced water (e.g. Brine } \\
\text { spill) }\end{array}$ & $\begin{array}{l}\text { Fracturing fluid and } \\
\text { wastewater from the Bakken } \\
\text { shale can reach and } \\
\text { accumulate in the soil and } \\
\text { remain unnoticed } \\
\text { Fracturing contaminants can } \\
\text { accumulate in food chain }\end{array}$ & $\begin{array}{l}\text { Soil characterization on Bakken's agricultural } \\
\text { yields needs detailed study }\end{array}$ & $\begin{array}{l}\text { (Ridlingto } \\
\text { n and } \\
\text { Rumpler, } \\
\text { 2013), } \\
\text { McLaughl } \\
\text { in et al., } \\
2016\end{array}$ \\
\hline 3 & $\begin{array}{l}\text { Wastewater } \\
\text { (Flowback } \\
\text { and } \\
\text { Produced } \\
\text { water) } \\
\text { management }\end{array}$ & $\begin{array}{l}\text { Wastewater handling, storage } \\
\text { and transportation }\end{array}$ & $\begin{array}{l}\text { HF wastewater spills can } \\
\text { contaminate water and soil. } \\
\text { No containment } \\
\text { management protocols in } \\
\text { place. } \\
\text { HF wastewater underground } \\
\text { pipeline database is not } \\
\text { comprehensive and } \\
\text { monitoring of underground } \\
\text { pipeline is challenging. } \\
\text { Unnoticed pipeline leaks } \\
\text { can gradually contaminate } \\
\text { ground water sources }\end{array}$ & $\begin{array}{l}\text { Prompt reporting of spills to the statutory } \\
\text { agency } \\
\text { HF water tankers going to class II injection } \\
\text { well should be required to carry certificate of } \\
\text { analysis with details of all constituent } \\
\text { chemicals to help predict. This will aid in } \\
\text { containing the potential spills. } \\
\text { Pipeline monitoring should be in place to } \\
\text { detect leaks }\end{array}$ & $\begin{array}{l}\text { (Gordon } \\
\text { and } \\
\text { Garner, } \\
\text { 2014) }\end{array}$ \\
\hline
\end{tabular}




\begin{tabular}{|c|c|c|c|}
\hline $\begin{array}{l}\text { Discharge of untreated } \\
\text { wastewater can contaminate } \\
\text { water resources }\end{array}$ & $\begin{array}{l}\text { Accumulation of metals and } \\
\text { radioactive elements in } \\
\text { water resources }\end{array}$ & $\begin{array}{l}\text { Treat the wastewater to meet the discharge } \\
\text { regulations }\end{array}$ & $\begin{array}{l}\text { (Igunnu } \\
\text { and Chen, } \\
\text { 2012) }\end{array}$ \\
\hline $\begin{array}{l}\text { Lack of continuous } \\
\text { monitoring and database }\end{array}$ & $\begin{array}{l}\text { Injection of brine water into } \\
\text { class II wells can alter the } \\
\text { geological formation and } \\
\text { lead to ground water } \\
\text { contamination }\end{array}$ & $\begin{array}{l}\text { Spatial and temporal distribution of seismic } \\
\text { measurements can be early indicators for } \\
\text { major catastrophic failure of class II wells }\end{array}$ & $\begin{array}{l}\text { (Frohlich } \\
\text { et al., } \\
\text { 2014) }\end{array}$ \\
\hline $\begin{array}{l}\text { Inorganic contamination } \\
\text { associated with brine spills in } \\
\text { ND is remarkably persistent, } \\
\text { up to } 4 \text { years following the } \\
\text { spill events }\end{array}$ & $\begin{array}{l}\text { The spill sites can threaten } \\
\text { surface and ground water } \\
\text { resources for several years } \\
\text { after the spill }\end{array}$ & $\begin{array}{l}\text { Future research should evaluate additional } \\
\text { spill sites, analyze organic contamination in } \\
\text { addition to inorganic elements, assess the } \\
\text { impacts downstream of spill sites, including } \\
\text { risks to drinking water sources, and conduct } \\
\text { acomprehensive assessment of long-term } \\
\text { ecological and possible human health impacts. }\end{array}$ & $\begin{array}{l}\text { (Lauer et } \\
\text { al.,2016) }\end{array}$ \\
\hline $\begin{array}{l}\text { Pipeline breaks and brine } \\
\text { spills }\end{array}$ & $\begin{array}{l}\text { Contamination of the } \\
\text { groundwater and surface } \\
\text { water resources }\end{array}$ & $\begin{array}{l}\text { More data on the fate and transport of } \\
\text { fracturing fluid organic constituents and their } \\
\text { transformation products are needed }\end{array}$ & $\begin{array}{l}\text { Rogers et } \\
\text { al.,2015), } \\
\text { (Parker et } \\
\text { al.,2014) }\end{array}$ \\
\hline $\begin{array}{l}\text { Lack of follow-up studies on } \\
\text { brine spills site in the Bakken }\end{array}$ & $\begin{array}{l}\text { Transport of contaminants } \\
\text { can continue to impact the } \\
\text { land and groundwater } \\
\text { longer than expected }\end{array}$ & $\begin{array}{l}\text { More retrospective studies should be done to } \\
\text { collect data on transport of fracturing fluid } \\
\text { constituents for longer monitoring duration }\end{array}$ & $\begin{array}{l}\text { (Rogers et } \\
\text { al.,2015) }\end{array}$ \\
\hline
\end{tabular}




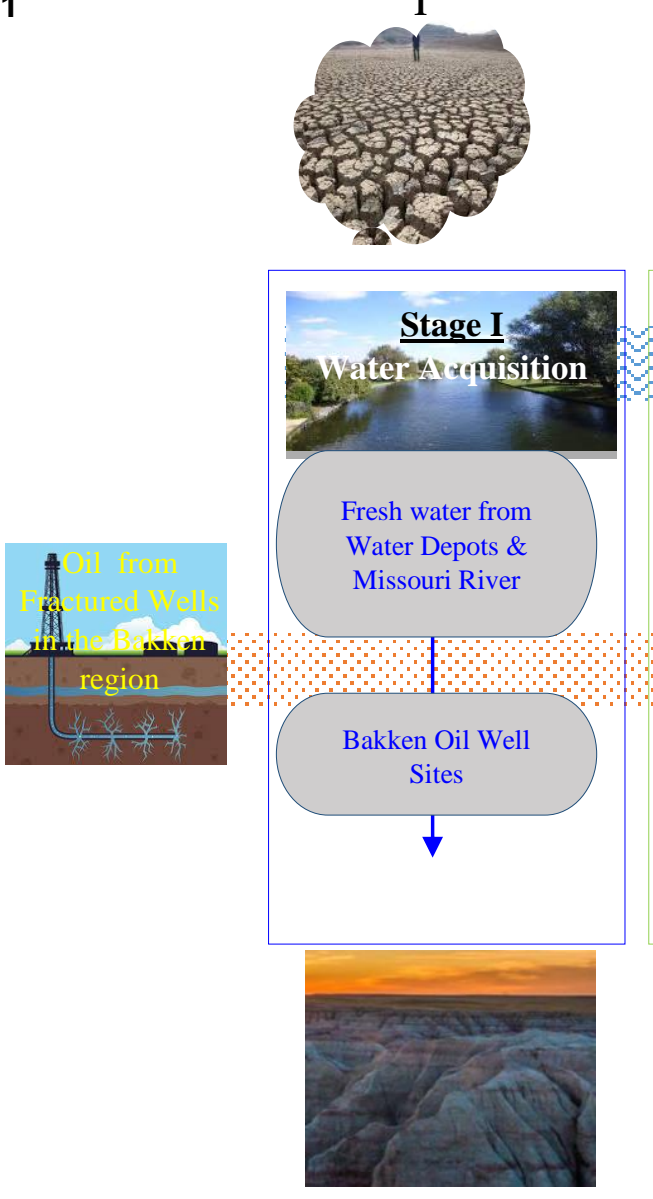

2
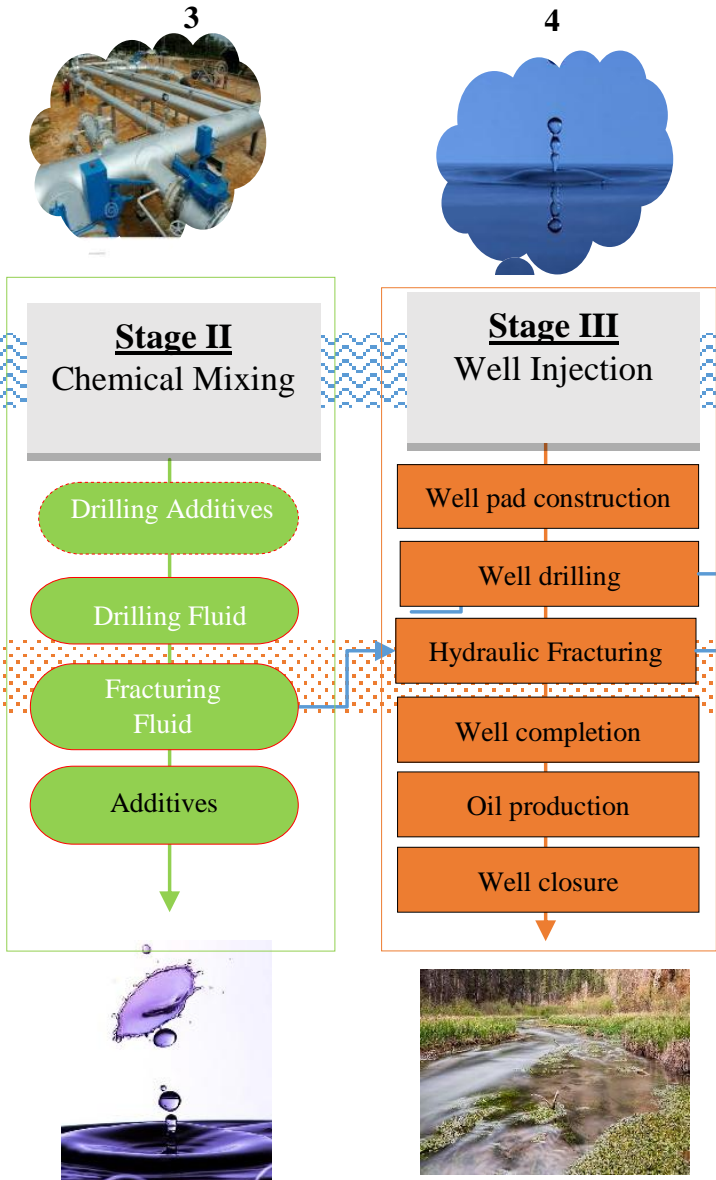

4
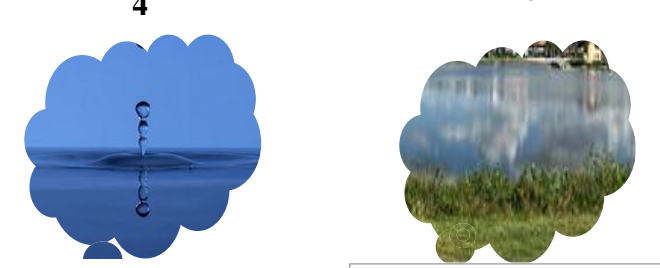

Stage IV

Flowback \&

Produced Water

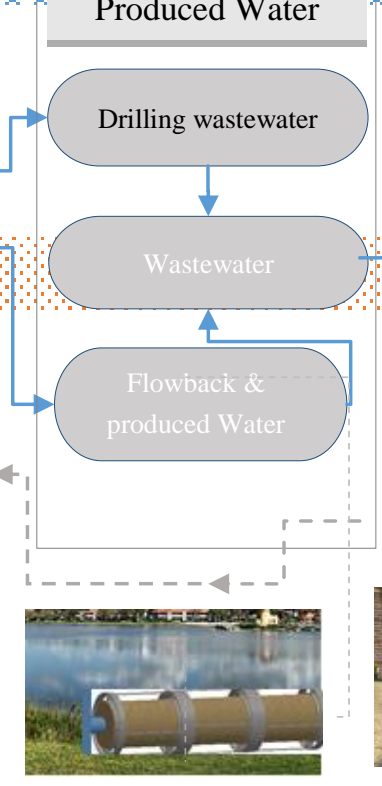

6

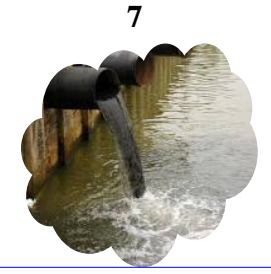

Stage V

Wastewater

Management
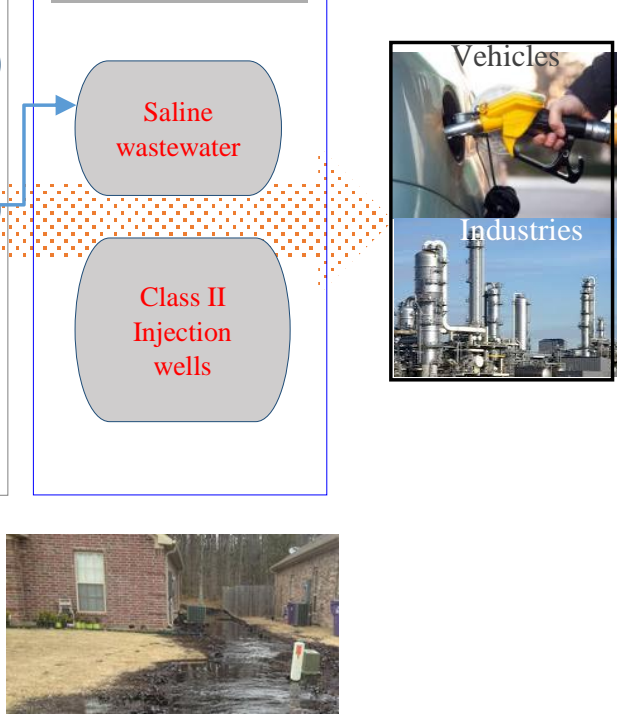

8

Figure 1. Potential water resource impacts due to the consumptive and non-consumptive water use for crude oil production from the Bakken shale (Hydraulic fracturing water lifecycle information adapted from U.S. EPA (2015), Chemical mixing and well injection sequence adapted from (Jiang et al., 2014)).

Note: Schematic illustration of possible modes of water resource impacts due to the ND Bakke shale oil development reviewed in this paper include: (1) Water stress due to excessive use of freshwater that can decrease the freshwater availability for agriculture, hydropower, drinking water and recreation; (2) Droughts due to overuse of freshwater in water-scarce areas; (3) Chemical leaks during mixing can water resources; (4) Chemical spills during mixing can contaminate water resources; (5) Infiltration of chemicals and wastewater into ground from stored pits due to poor well casing/ storage design; (6) Pipeline breaks during wastewater transporting can contaminate water and land resources; (7) Discharge of untreated wastewater can contaminate receiving water bodies; and (8) surface spills and leakage during treatment, storage and treatment can result in surface water and shallow groundwater contamination 


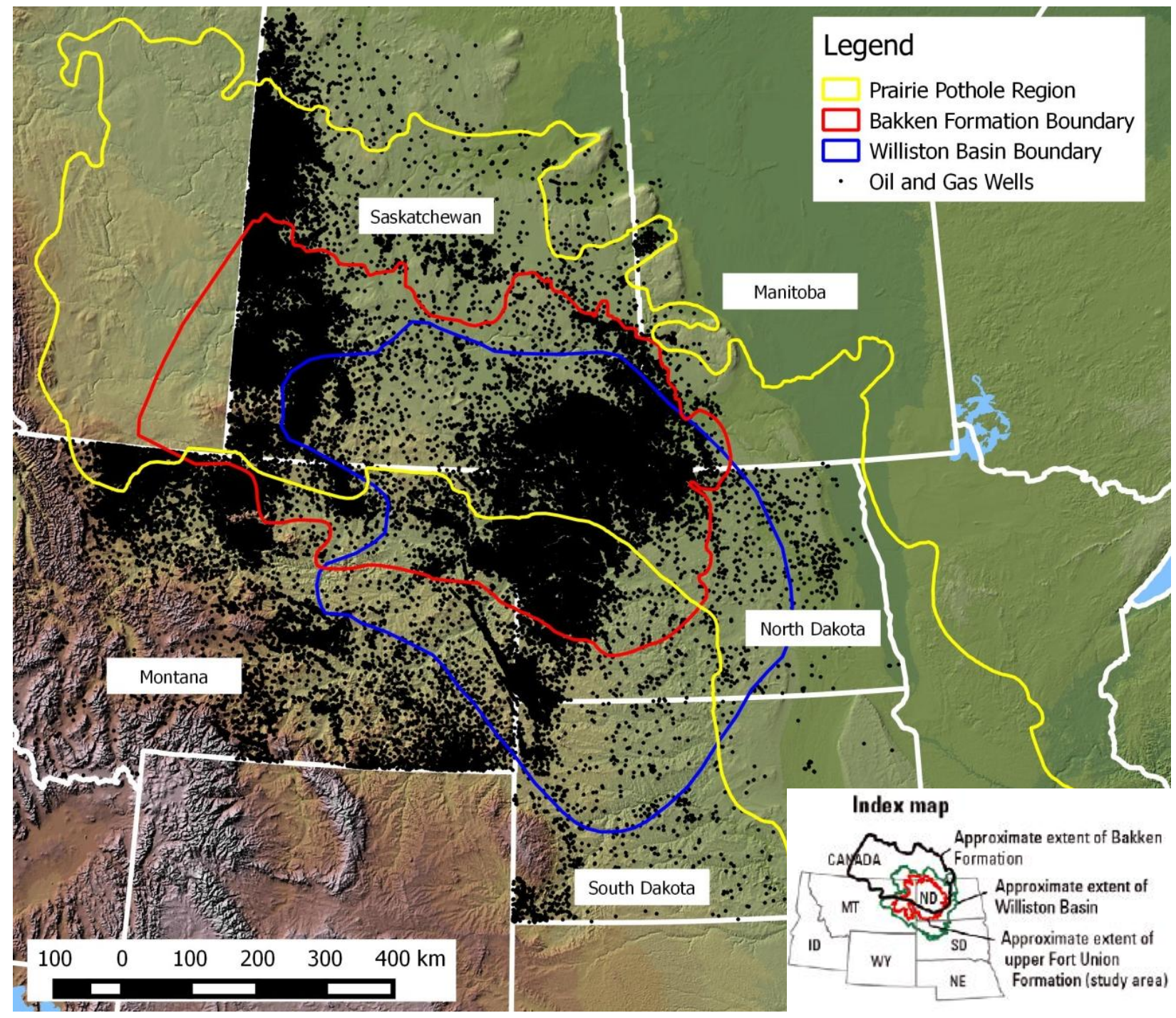

Figure 2. Topographical map showing the Williston basin boundary (highlighted in blue), the prairie pothole regions (highlighted in yellow), the Bakken formation boundary (highlighted in red), and the oil and gas wells (highlighted in black) (With permission from (U.S.Geological Survey, 2015) ).

Note: Inset shows the extent of Williston basin, and Bakken and upper Fort union formation in the Upper Great Plain (UGP) regions including SD, ND, MT, WY, and NE. 

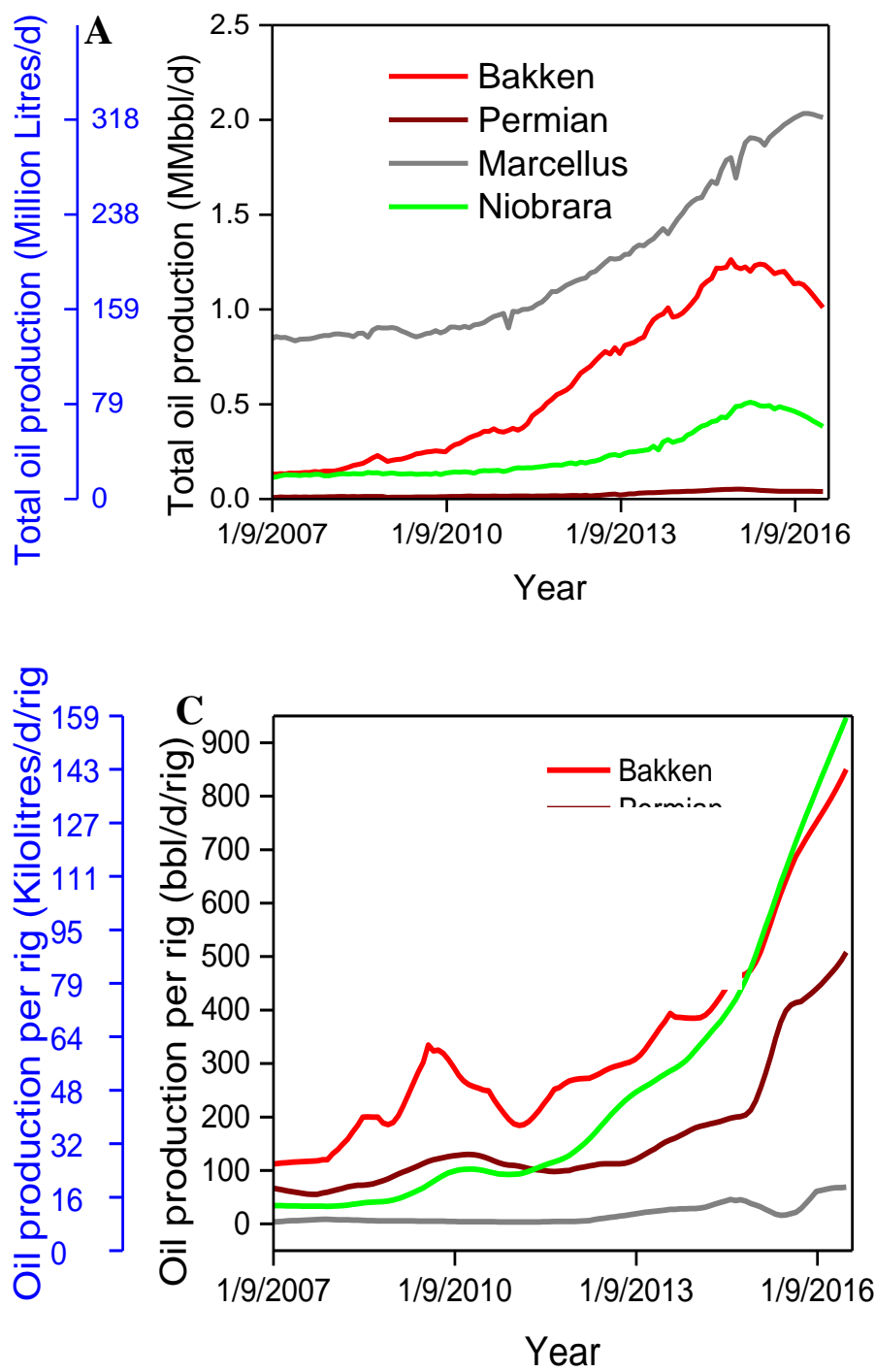
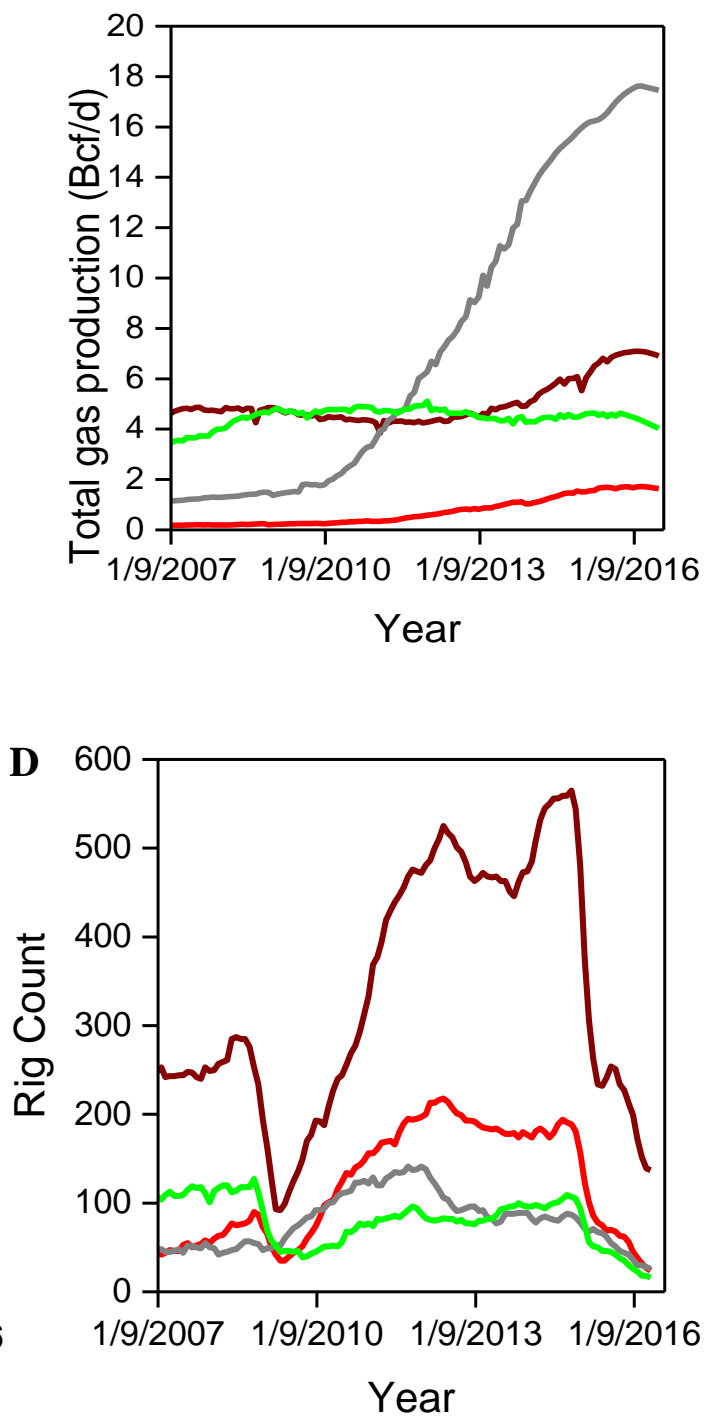

Figure 3. Comparison of drilling productivity for the Bakken shale with the Permian, Marcellus, and Niobrara shales from 2007 to 2016: a) Total crude oil production (MMbbl/d) or (Million Litres/d), b) Total natural gas production (Bcf/d), c) oil production per rig (bbl/d/rig) or (Kilolitres/d/rig), and d) Rig count (Adapted from (U.S. EIA, 2015)) 
a)

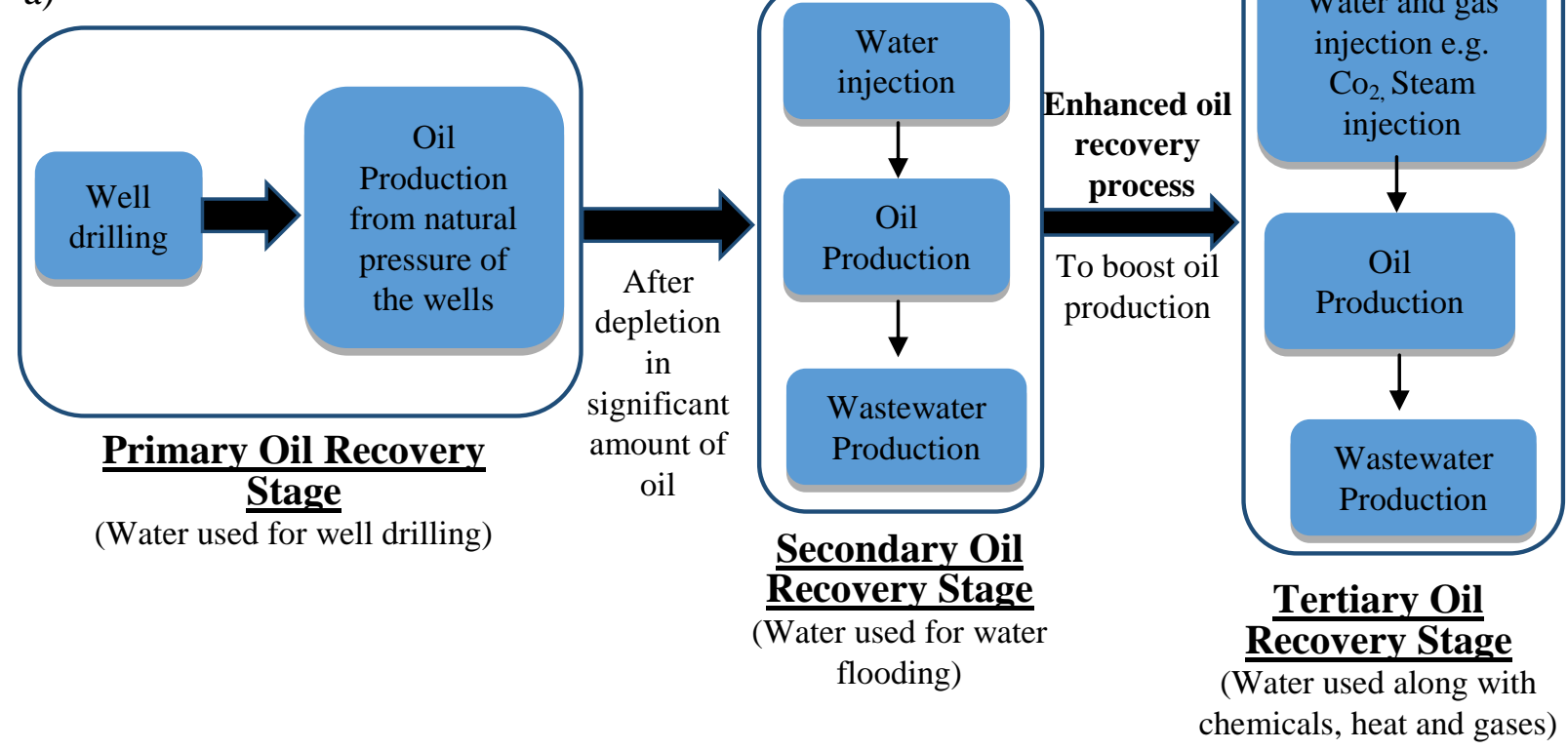

b)
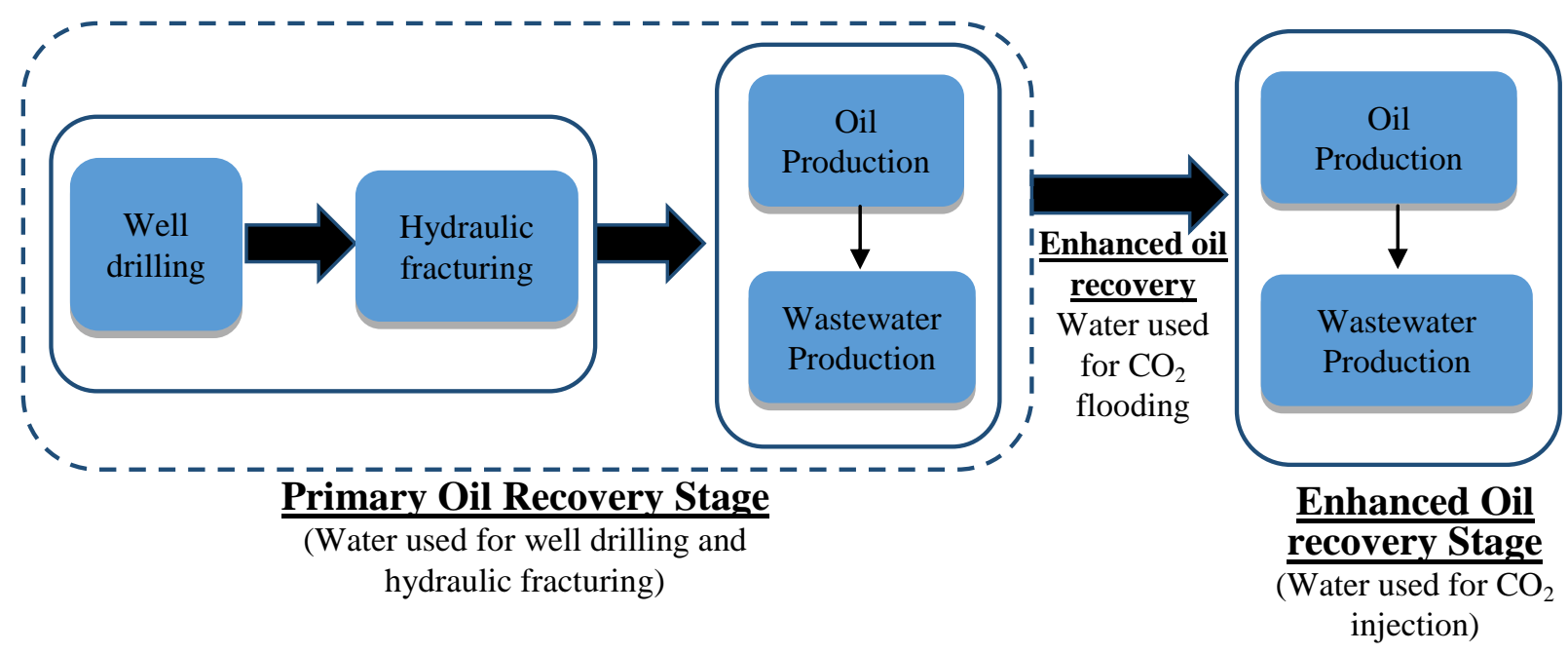

Figure 4. Water consumption during the three different stages of the crude oil recovery: a) Conventional Oil Production b) Unconventional Oil Production (Adapted Wu and Chiu (2011)) 
a)

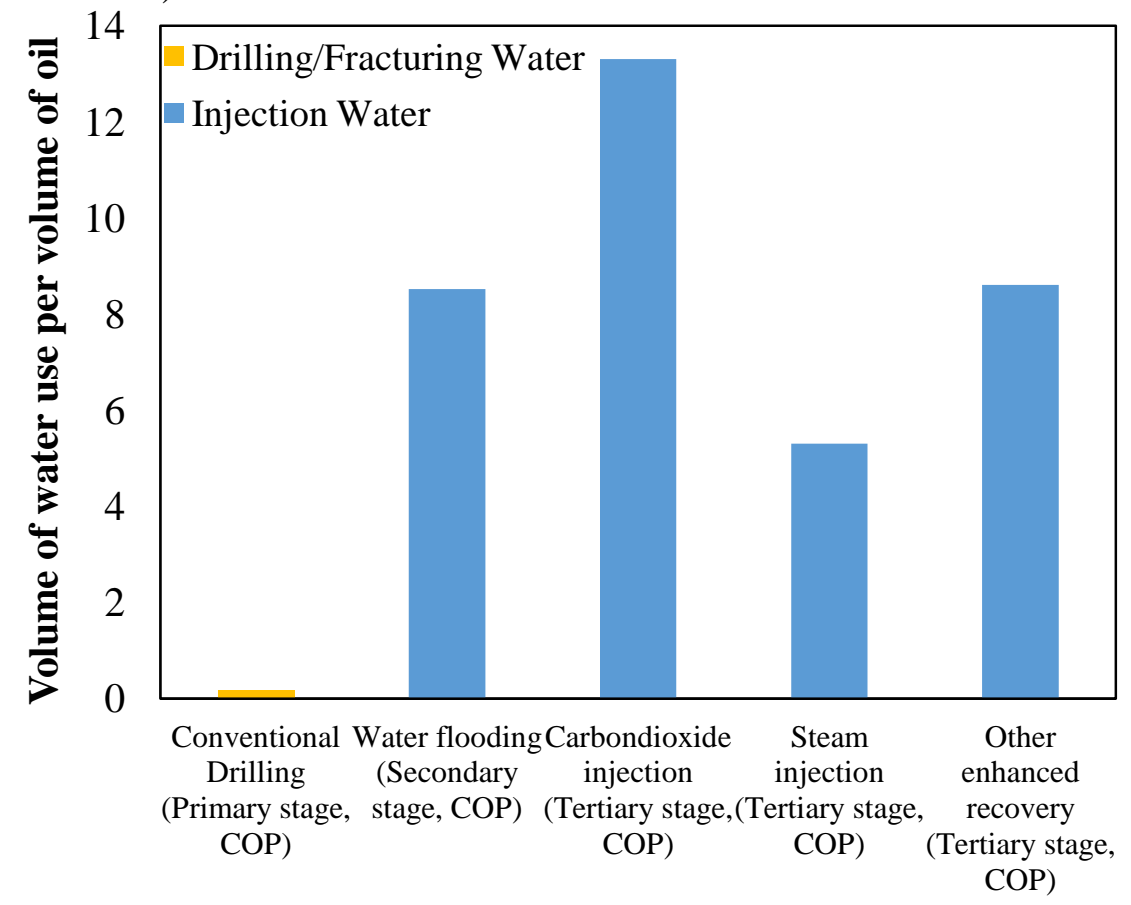

b)

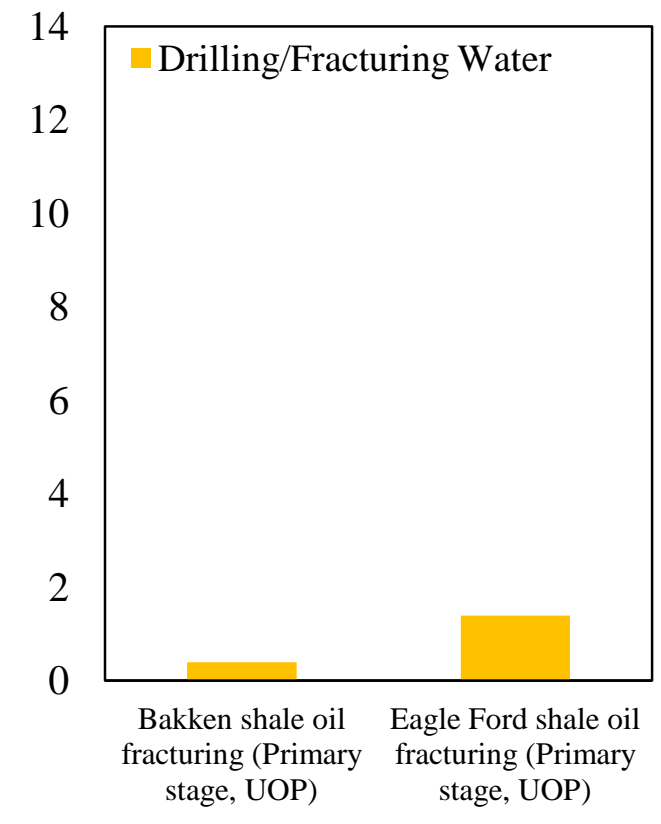

Figure 5. Comparison of water injection for three different oil recovery stages throughout the lifecycle of petroleum reservoirs. a) Water consumption for COP b) Water consumption for UOP (Adapted from Lampert (2015), Wu and Chiu (2011)

Note: COP refers to conventional oil production, UOP refers to unconventional oil production 


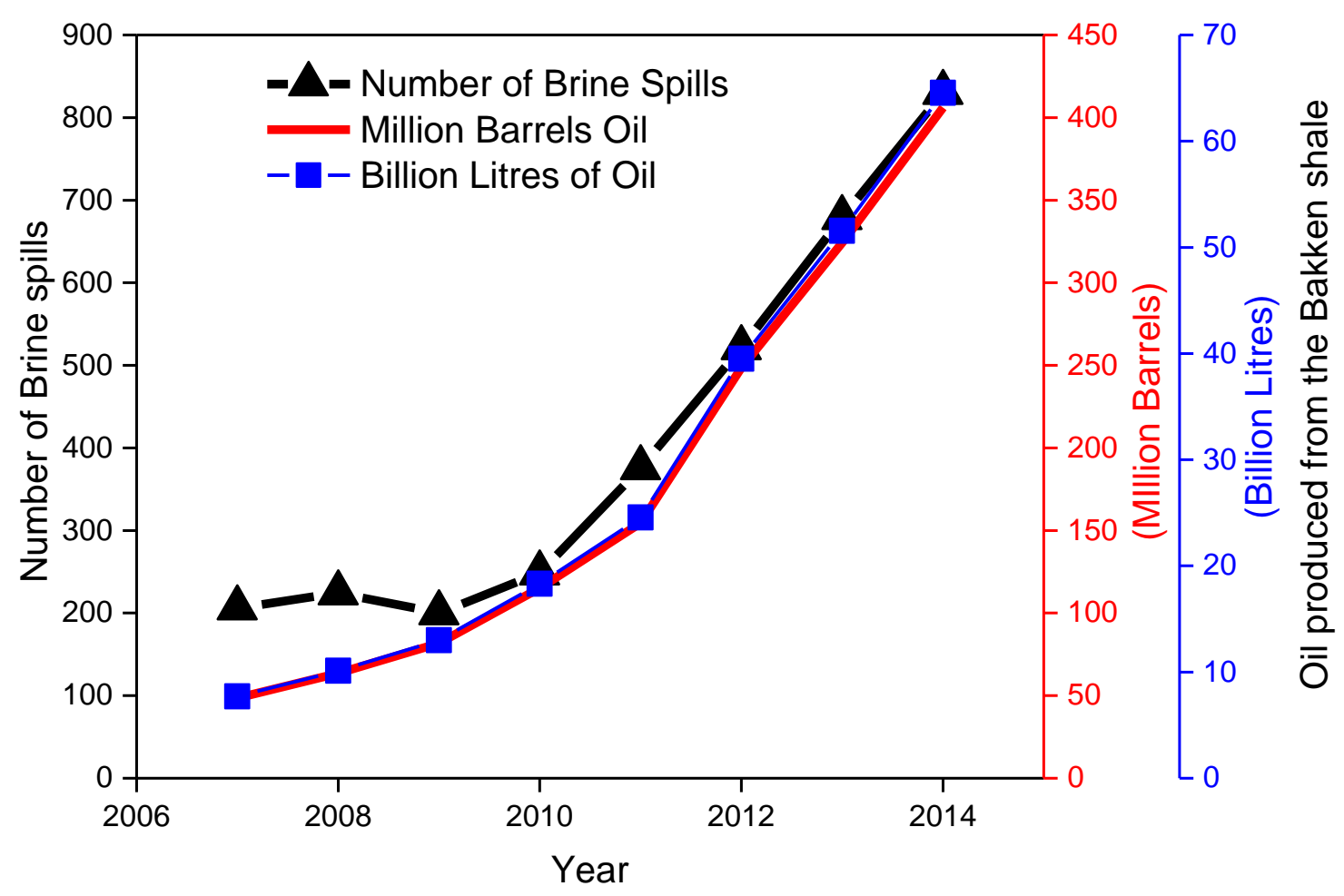

Figure 6. Parallel rise of annual Bakken oil production and number of spills in North Dakota from 2007 to 2014. Data compiled from North Dakota Department of Health and Lauer et al., (2016) 
a)

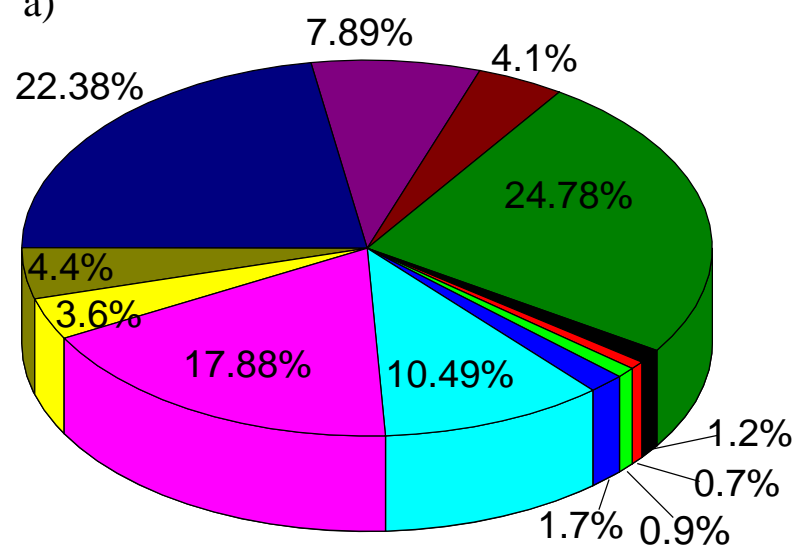

Vessel leak

Blowout

Equipment failure

Fire

Other

Pipeline leak

Pump Leak

Stuffing Box Leak

Tank leak or Overflow

Treater Leak or Popoff

Truck Overflow

Valve/Piping Connection Leak
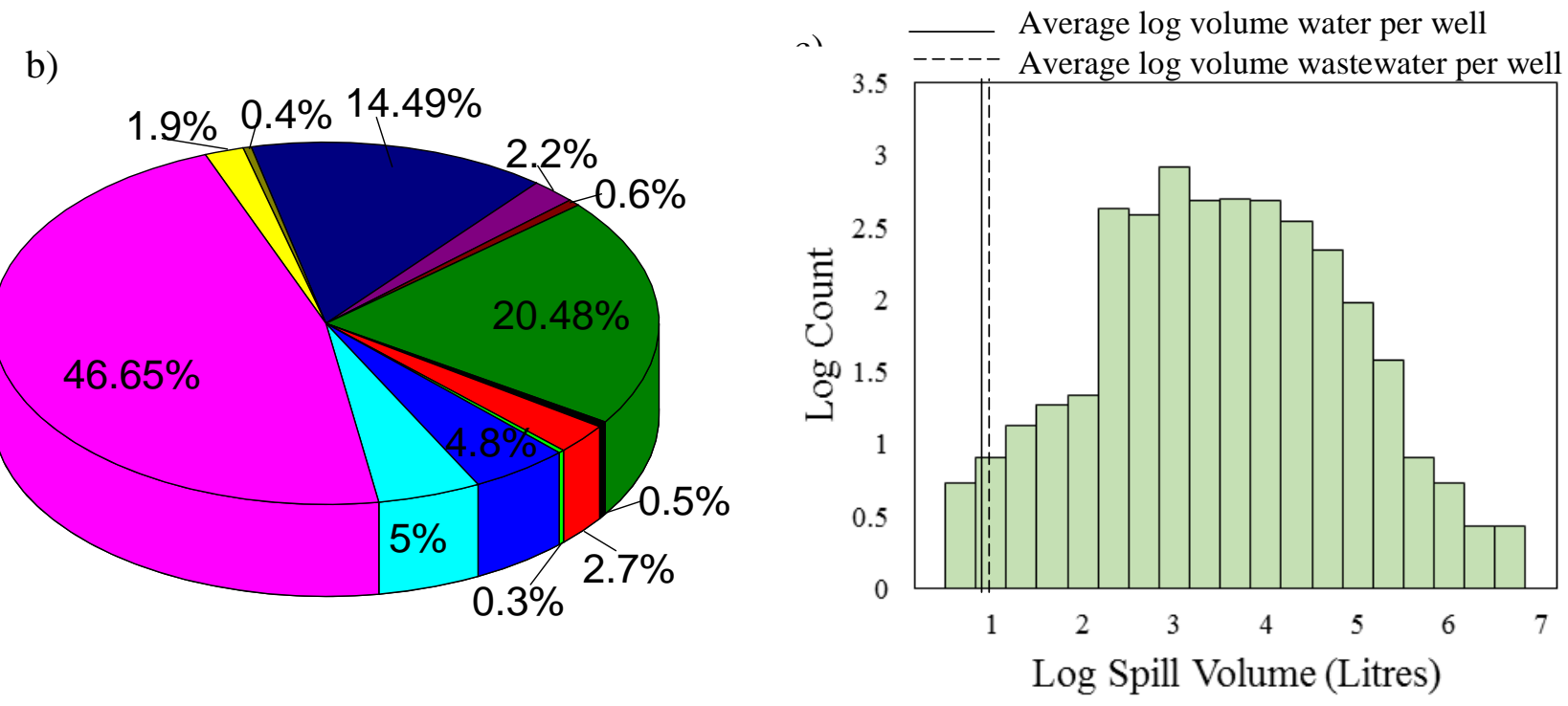

Figure 7. The distribution of brine spills sources in North Dakota based on (a) the number of spills and, (b) the volume of spilled brine. Data were compiled from North Dakota Department of Health: Environmental Releases \& Investigations c) Brine spills volumes in North Dakota since 2007. Data were compiled from North Dakota Department of Health: Environmental Releases \& Investigations. (https://www.ndhealth.gov/WQ/GW/spills.htm) and Lauer et al., (2016).

Note: The figure includes only brines spill during year 2006-2014. Oil spills during the given year are not considered. 


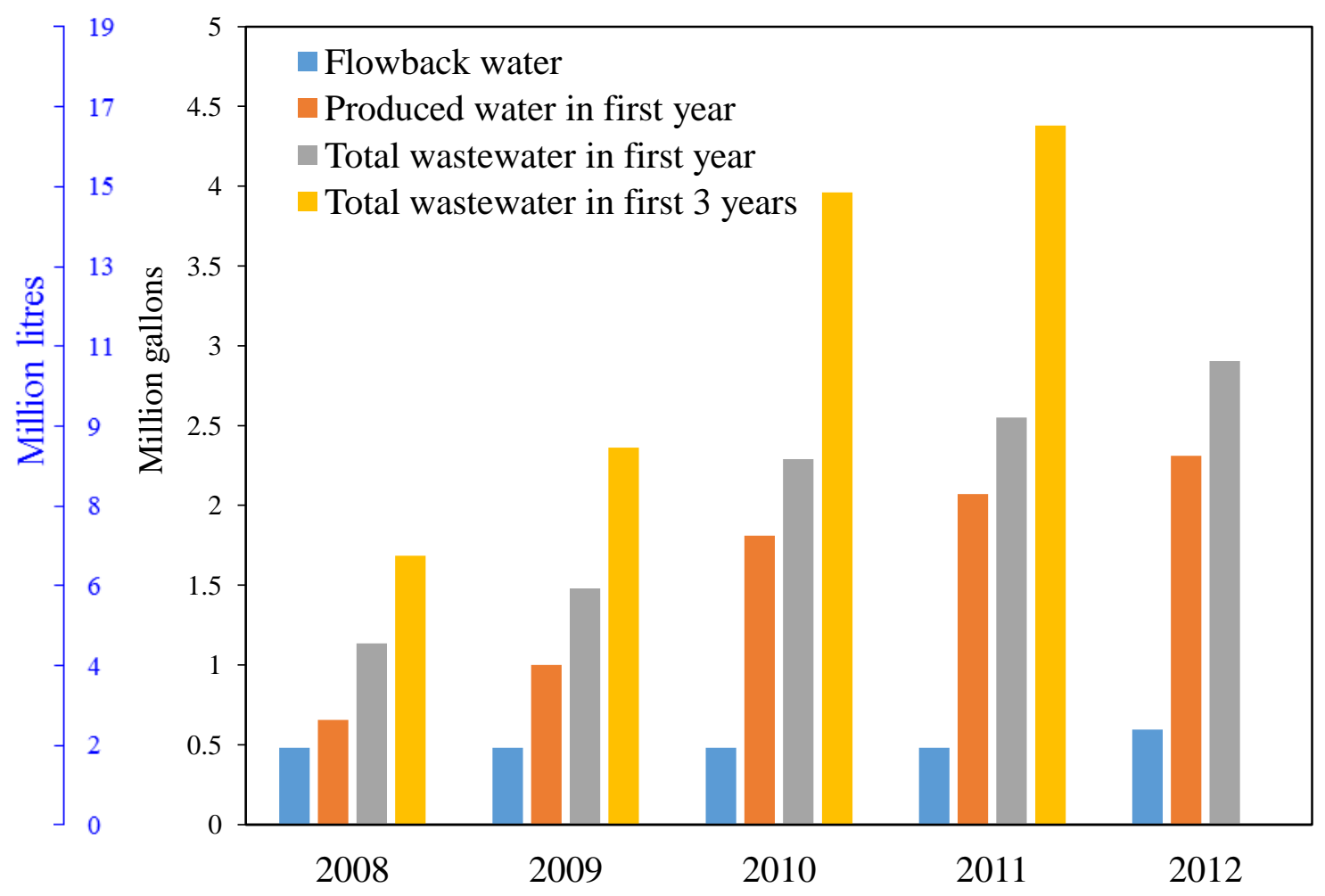

Figure 8. Average Flowback and Produced Water per Well in the First 1 and 3 Years of Production. Adapted from Horner et al., (2016) 